
Class 552,1

Coysigith lo coppy 2

COFXRIGHT DEPOSIT 






THE FARMER

AND THE NEW DAY 


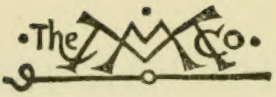

THE MACMILLAN COMPANY

NEW YORK - BOSTON - CHICAGO - DALLAS

ATLANTA - SAN FRANCISCO

MACMILLAN \& CO., LIMITED

LONDON - BOMBAY - CALCUTTA

MELBOURNE

THE MACMILLAN CO. OF CANADA, LTD.

TORONTO 


\section{THE FARMER \\ AND THE NEW DAY}

BY

KENYON L. BUTTERFIELD

President Massachusetts Agricultural College

Mew 奜ark

THE MACMILLAN COMPANY

1919

All rights reserved

Copong 2 


\section{1}

CoprRaHT 1919

BT THE MACMILLAN COMPANY

Set up and electrotyped. Published, February, 1919

$\because ?-3$

(C) C.A. $\div 1: 2 \div 4$ 
To the "Old Guard" of the Michigan State Grange; to those still living and in memory of those who have passed beyond:

(UTO Jonathan J. Woodman, Cyrus G. Luce, Thomas Mars, George B. Horton, Mary A. Mayo, and others of the leaders of a quarter century ago:

I sat at their feet as a young man fresh from college; under them I took my most valuable graduate course; from them I learned the character of the American Farmer of the best type, his problems, his aspirations, his faith; from their plans and labor for the upbuilding of agriculture and farm life I gained the desire to see the rural problem as a whole and to discover the fundamentals of its solution:

(1) $O$ them and their many loyal and earnest contemporaries I dedicate this effort to express my convictions concerning the ultimate welfare of the American Farmer.

THe Author. 

"How shall he become wise that holdeth the plow, that glorieth in the shaft of the goad, that driveth oxen, and is occupied in their labors, and whose discourse is of the stock of bulls? He will set his heart upon turning his furrows; and his wakefulness is to give his heifers their fodder. So is every artificer and workmaster ... the smith sitting by the anvil ... the potter sitting at his work.

"All these put their trust in their hands; and each becometh wise in his own work. Without these shall not a city be inhabited, and men shall not sojourn nor walk up and down therein. But they shall not be sought for in the council of the people, and in the assembly they shall not mount high; they shall not sit on the seat of the judge, and they shall not understand the covenant of judgment; neither shall they declare instruction and judgment, and where parables are they shall not be found. But they will maintain the fabric of the world; and in the handywork of their craft is their prayer.

"Not so he that hath applied his soul, and meditateth in the law of the Most High. He will seek out the wisdom of all the ancients, and will be occupied in prophecies. He will keep the discourse of the men of renown, and will enter in amidst the subtilties of parables. He will seek out the hidden meaning of proverbs, and be conversant in the dark sayings of parables. He will serve among great men, and appear before him that ruleth."

- Ecclesiasticus.

"Our civilization rests at bottom on the wholesomeness, the attractiveness, and the completeness, as well as the prosperity, of life in the country."

- Theodore Roosevelt, 1909.

"Every sign of these terrible days of war and revolutionary change, when economic and social forces are being released upon 
the world whose effect no political seer dare venture to conjecture, bids us search our hearts through and through and make them ready for the birth of a new day - a day, we hope and believe, of greater opportunity and greater prosperity for the average mass of struggling men and women, and of greater safety and opportunity for children.

"Men everywhere are searching democratic principles to their hearts in order to determine their soundness, their sincerity, their adaptability to the real needs of their life, and every man with any vision must see that the real test of justice and right action is presently to come as it never came before.

" . . every program, every measure in every program must be tested by this question, and this question only: Is it just; is it for the benefit of the average man, without influence of privilege: does it embody in real fact the highest conception of social justice and of right dealing without respect of person or class or particular interest?"

- President Wilson, March, 1918. 


\section{PREFACE}

FoR many years I have been meditating upon the matters that have been written about in this book. I have lectured about them to students and talked about them to farmers and other folks. Long ago I planned to write them out in a book or series of books, but I have found it nearly impossible to write satisfactorily in the midst of administrative duties. Good thinking and good writing on themes such as these require from most of us, time, fresh energy, and sufficient relaxation of mind to enable one to chew the cuds of reflection. Executives find it difficult to secure these requisites. I am finishing these pages under the pressure of a demand to join at once colleagues overseas in educational work among our soldiers.

All that I have attempted in this book, is to endeavor to state the larger problems which the farmer must face during reconstruction and to indicate the significance and character of the relations between him and the rest of society in this new era. There has been little attempt to furnish solutions of specific problems; rather to indicate a few of the fundamental principles and methods by which agricultural improvement and an adjustment to world affairs can be made.

My thanks are due to colleagues in the Division of Rural Social Science at the Massachusetts Agricultural College, Dr. Alexander E. Cance and Professor John Phelan, for helpful comment and criticism; and par- 


\section{PREFACE}

ticularly to Miss Lorian P. Jefferson, Assistant Professor in the Division, for close reading of both manuscript and proof. Indeed, I am obliged to leave for France before the proof is read.

Kenyon L. Butterfield.

Amherst, Massachusetts.

November, I918. 


\section{CONTENTS}

\section{THE RURAL PROBLEM}

CHAPTER PAGE

I Is the Farmer Coming to His OWn? . . . I

II The Challenge of the New Day . . . . 19

III The Rural Problem - • . . . . . . 30

IV Farm Profits and Rural Welfare • . 57

V Farming That Is Not Farming . . . . 70

\section{RURAL ORGANIZATION}

VI Wanted: A Rural Policy . . . . . 84 VII The Education of the Rural People . 106 ViII The Organization of American Agriculture and Country Life . . . . . . . . 122

iX The Making of Rural Cominunities . . 142

$X$ Organizing the Rural Community : . 165

XI The Statesmanship of Rural Affairs . . I9I

\section{A RURAL DEMOCRACY}

XiI The Farmer and the New Democracy . . 2 II XiII An American Program of Rural ReconSTRUCTION . . . . . . . . . 226 XIV The URge of THE NeW Day $\dot{D}^{\circ} \cdot{ }^{\circ} \cdot 26 \mathrm{I}$

\section{APPENDICES}

I The Forum and the Community . . . . 27 I

II What Some Communities are Doing • . 274

III Program for Food Production and ConservaTION . . . . . . . . . . . 28I IV An American Agricultural Policy : . 29 I 



\section{THE FARMER AND THE NEW DAY}

\section{CHAPTER I}

\section{IS THE FARMER COMING TO HIS OWN?}

MANY centuries ago a certain wise man said that he that holdeth the plow, and driveth oxen, as well as every artificer, all who put their trust in their hands, shall not be sought for in the council of wise men who have leisure in which to prophesy, and to enter into the subtleties of parables. What he meant to say was that the common people are fundamentally necessary to the world but do not govern the world.

A few months ago another wise man, perhaps the most far-sighted of his generation, bade us "search our hearts through and through and make them ready for the birth of a New Day - a day, we hope and believe, of greater opportunity . . . for the average mass of struggling men and women."

Which of these principles of human development and influence is to prevail in the years and centuries ahead of us? Which of these wise men is the true prophet for our time - he who condemned the common man to a position of minor influence in society, or he who sees a new day for the average man?

\section{THE FARMER AS UNDERLING}

It is certain that during the centuries that have passed since the wise man of Ecclesiasticus painted his picture 
of the peasant, in most times and in most places, the farmer has been an underling. Even the land that he tilled has not been his own. In great spaces of the earth the farmer was for ages an actual slave. In some regions even to-day he belongs to the land and, if the land is sold, he goes with it to the new owner. If any country is dark with illiteracy, ignorance, and superstition, it will be found that the blackest areas are the rural districts. The soil tiller has at the worst been serf and clout, and at the best, with a few shining exceptions, rustic or peasant. Rarely indeed has he sat at the council-board of those who determined the destinies of peoples or even had a voice in the policies that governed his own work and life.

\section{THE SHINING EXCEPTIONS}

In republican Rome the farmer seems to have been held in respect and to have had a satisfactory place in the business of the time. Of the standing of Roman farmers in general, Cato says that when a Roman wished to commend an honest man he termed him a good husbandman, a good farmer. This was rated the superlative of praise. It was, he continues, from the tillers of the soil that sprang the best citizens, the stanchest soldiers, and theirs were the most enduring rewards. A survey of Roman literature reveals many a prominent name made famous chiefly through writings on agricultural subjects. Cato, farmer, soldier, lawyer, is known to us almost wholly through his $D_{e} R_{e}$ Rustica, which reveals his wide farm experience. Varro, "the most learned of the Romans," left to the world the best practical work on farm management which has come down to us from the ancients - Rerum Rusticarum, a careful statement of actual experience 
and knowledge of a successful farmer. Virgil discoursed on the joys of country life. Cincinnatus left his plow for war on behalf of his country. Agriculture for centuries was the bed-rock of Rome's strength, and farmers were not kept out of the councils of the wise.

Again we find an exception to the dreary monotony of rural dependency in the English "yeoman." Of a population of perhaps two and one-half millions in England in the seventeenth century, it is estimated that not less than eleven-twelfths were engaged in agriculture. According to statistics for the year 1688, there were I 80,000 families of yeomen, known as freeholders, and I 50,000 families of farmers. These figures are significant in connection with a total of $1,360,000$ families in England at the time. The freeholders were actual farm owners, living on the soil, and the farmers were those tenants who paid an annual rent for their holdings about equal to the annual value of the farm. The middle of the seventeenth century was the time when the English yeomen enjoyed the greatest freedom and prosperity. They owned their own land or rented it on favorable terms and for desirable periods; they were sturdy and independent, often daring to oppose, "in voting and in fighting," the neighboring squire. One writer of the period said, "The yeomanry is an estate of people almost peculiar to England; [he] wears russet clothes, but makes golden payments, having tin in his buttons but silver in his pockets. He seldom goes abroad, and his credit goes farther than his travel." Economically the farmers [tenants] were about equal to the freeholders, differing considerably, however, in social standing. 


\section{THE FARMER AND THE NEW DAY}

\section{MODERN RAINBOWS OF PROMISE}

During the past fifty years there has grown up in certain European countries a new treatment of the farmer and in some respects a new attitude toward him. He has acquired a new power in affairs. Perhaps the most conspicuous examples of this new situation are Germany, Denmark, and Ireland. Other countries, such as Holland, Belgium, Switzerland, France, and even Italy, in many ways stand out in the light of a splendid progress and an intelligent statesmanship in rural afiairs. But on the whole the three countries first named are the best illustrations of a rural development which has been planned in advance; each country has made a special contribution to rural improvement.

Germany had probably developed before the war the most far-reaching agricultural policy that we know - a policy grounded in national aspirations and designs. The principles underlying this policy were simple enough, especially as we view them now in the light of the world war. Germany encouraged agriculture for two great reasons: (I) That she might feed herself in time of war; (2) that she might breed soldiers. Her tariffs on food products; her encouragement of collective selling of farm products and of collective purchase of farm requirements; her remarkable machinery for furnishing the farmer with both short-time and long-time credit; her more than tolerance of great associations of farmers and the granting of semi-official standing to their leaders; her widespread and very effective system of agricultural education - all these (added to the fact that German agriculture, and consequently the very structure of German society itself, rests 
upon the broad back of German farm women) made Germany all but self-sustaining at the time she chose war for her portion. Her encouragement of small farming and large families, her methods of "keeping boys on the farm," her care of public health, added to her system of military training, gave her the huge armies that she flung into Belgium and France, into Russia and the Balkans. Thus Germany, pursuing for two generations a consistent agricultural policy, was enabled, on a soil originally not especially rich and from an area smaller than that of the state of Texas, to provide perhaps nine-tenths of the food for her seventy millions of people. Her attitude toward agriculture, it may be said in passing, won for her militaristic policy the support of the agricultural classes. Thus, while we detest the spirit and method of the Germany that is responsible for the horrible carnage of the world war, we find in that country that the soil tiller came to a place of comparative influence and power.

Denmark, in $\mathrm{I} 866$, found herself deprived of the richest part of her soil by the war with Germany. She had few manufactures and has not many to-day. She had little capital but grit, a vision of a complete agriculture and wonderful leadership. In half a century she developed probably the most fully organized and generally prosperous agriculture of any political area in the world. She chose a few products on which to specialize, those to which she was best adapted and for which a market could be found. Danish butter, Danish bacon, and Danish eggs made their way against all competitors and caused the Danish farmer to become a factor not only at home but in the national economy of other countries.

For decades and even centuries Ireland was the land 


\section{THE IARMER AND THE NEW DAY}

of political protest and rebellion. Her sons and daughters left her by millions, her poverty both in city and in country grew apace. Absentee landlordism became a stench and a byword among the terribly poor tenantry. And then a prophet arose in that land and proclaimed a new gospel of reformation. Horace Plunkett had a simple message that went to the root of the situation; Ireland's farming must be rehabilitated; her land must be owned by those who till it; the day of the lone farmer has passed and the day of the rural coöperation has dawned; there must be a new rural civilization, adequate and satisfying economically and socially; self-sustaining local rural communities must be built up as the bulwark of a true democracy of work and life as well as of government. And so, by 1914, half of Ireland's farm land had passed from big landlord to little farmer - the "family size" farm was the unit of measure - hundreds of coöperative societies were in active and successful operation, the spirit of coöperation had succeeded to the spirit of apartness. The flame of Irish enthusiasm and endeavor on behalf of rural interests has been carried to our own shores and has lighted many a torch of leadership in rural affairs.

\section{SOME LESSONS FOR US}

It is worth while to take note of the underlying methods and results of these great national enterprises in agricultural betterment, for they may have some valuable lessons for us in America. Germany, with its far-reaching agricultural policy; Denmark, with its very complete, almost perfect system of coöperative effort in production and sale of food; Ireland, with its ideals of social development and rural community building these countries, together with the others already named, 


\section{COMING TO HIS OWN?}

seem to have brought the farmer into a new and higher position in the business and life of the nations. What are the fundamental conditions under which this change was accomplished?

I. First was the spur of necessity. At bottom it was the competition from America, Argentina, and Australia, or some serious internal difficulty that forced the European farmer into the depths of despair and thus compelled statesmen to plan for his recuperation. "Something had to be done."

2. The great principles of improvement which were recognized and used at every turn were education and organization. Neither was more important than the other; both were indispensable and neither alone was efficient. Organization meant governmental approval, recognition, and even financial aid in all efforts at voluntary coöperation among farmers, especially in the business side of farming - selling products, buying supplies, and various forms of collective credit and insurance. Even in Germany, in spite of an opinion to the contrary, the main idea was for government to help farmers to help themselves. Education meant a widespread system of technical education in agriculture adapted to all degrees of intelligence, placed within reach of every youth and every adult living on the land. In some cases, the great coöperative societies carried on this educational work themselves, but always as a real part of a publicly supported and thoroughly organized system.

3. There was developed in each country a well planned and fairly definite agricultural program. This program was capable of being put upon paper. It had been hammered out in conferences of all the interests concerned. It was relatively stable. It was a plan 


\section{8

of agricultural improvement recognized by farmers as meeting their needs and by statesmen as fitting into national welfare.

4. Finally, agriculture came to be recognized as a national factor, to be planned for and worked with for large national ends. It was no longer a neglected element. And so the leaders among the farmers were in a sense received at court; they did "sit with the wise men at the gate of the city."

Thus when the great war broke out in I 9 I 4 , it seemed as if in many parts of Europe the farmer had in a measure at last come to his own. It still remains to be seen whether, in the reëstablishment of peaceful occupations, and particularly in the democratization of autocratic states, the farmer is to have a full share of responsibility and power.

\section{THE AMERICAN FARMER}

The final and the greatest exception to the general position of the farmer in society is the Imerican farmer. In no age cf history and in no country has there been nor is there now his equal. American farm life has bred the most skillful farmers, the most intelligent rural citizens, the most engaging farm homes to be found anywhere in the world. This praise applies to the real American farmer, the owner and active manager of a family-size farm, who came of the best blood of pioneer America, whose intelligence is comparable with that of the leading groups of citizens of the Republic, many of whose sons and daughters have made their way into recognized leadership in business, industry, and the professions. It is difficult to speak with restraint of this man or his achievements. He conquered a huge 
continent of rich soil for civilization. He carried to the frontier an eager desire for education, the democratic impulse, and the fear of the Lord. He has helped fight his country's battles. He has been the bedrock of representative government. His independent spirit, his abundant energy, his high intelligence have made him without a peer among the tillers of the soil. His income is supposed to be two and one-half times that of the English farmer, three times that of the German farmer, and six times that of the Italian farmer.

A rather careful survey of the agricultural production of different nations indicates that the production of the American farmer, whether considered by himself or with all those dependent upon him, is several times that of the German, British, French, or Italian farmer. The exact relation may be shown in the following table, in which an arbitrary index figure is used to show relative values. If we call the index of productivity for each American engaged in agriculture 292 ; the index for the British farmer is 126 ; for each German farmer, II 9; for the French farmer, 90; and for the Italian farmer, 45. That is to say, the volume of productivity of each American engaged in agriculture is about two and one-half times that of the English agriculturist, nearly three times that of the German farmer, and six times that of the Italian.

Fixing at $\mathrm{I}, 000$ the productivity of each American dependent on agriculture, which includes all persons gainfully employed in agriculture as well as those dependent on them, the German index will be 685 , or 68 per cent. as much; for the Briton, 425 , or 42 per cent.; for the Frenchman, 406 , or 40 per cent.; and for the Italian 230 , or 23 per cent. Of course this table 
merely shows that for each person employed in agriculture in America, there are more unemployed dependents than there are in other countries.

\section{Index of productivity per person:}

For each American dependent upon agriculture. . . 1004 For each German dependent upon agriculture.... 685 For each Briton dependent upon agriculture .... 425 For each Frenchman dependent upon agriculture . 406 For each Italian dependent upon agriculture.... 230

\section{Index of productivity per person:}

For each American engaged in agriculture..... 292

For each Briton engaged in agriculture........ 126

For each German engaged in agriculture....... I 19

For each Frenchman engaged in agriculture ..... 90

For each Italian engaged in agriculture....... 45

\section{RIFTS IN THE LUTE}

But there has been another side to the story. The pioneer experiences were trying, often discouraging. not seldom heart-breaking. There have been poor farmers both on poor land and on good land, as well as good farmers on poor land, with resulting inefficiency. Farming regions have competed for the markets. Financial returns have often been meager, many total failures have ensued, mortgages have been foreclosed, women have gone insane from isolation and drudgery. These and other discouragements have from time to time resulted in organized protest; the great farmers' organizations of the country have all grown out of the spur of disadvantages to masses of farmers. The dissatisfaction of farmers was peculiarly acute during the period from about $1 \& 75$ to $1 \$ 95$. 
Since 1895 the rapidly decreasing percentage of new lands coming under cultivation, with a resulting decline in ratio between farm producers and urban consumers, the freer absorption of the food supply by both American and foreign markets, the gradual rise in price levels have given us an era of relative rural prosperity. Indeed some of the evidences of this prosperity in the form of the free purchase and use of automobiles, enormous statistical aggregates of value of animal and field production, the ability of many farmers to "retire" during middle life, have blinded us to sinister tendencies that have been creeping into our American agriculture as silently and as relentlessly as the inflowing tides of the sea. Without aiming to make a complete statement of these depressing facts, it will suffice to mention those that seem to be most significant in a bearing upon the question whether or not the American farmer will hold his own.

I. The great majority of American farmers are not to-day securing from their labor a reward which they regard as fair to themselves, nor one which students of social science consider satisfactory from the standpoint of minimum requirements for a decent living. The best figures obtainable indicate an average labor income for the American farmer of $\$ 400$ per year. There are some states, indeed some whole regions, where farmers on the whole are very prosperous; but this fact merely adds force to the discouragingly meager income in those areas where the returns are at or below the average.

2. There is a widespread, almost a universal, belief among farmers that, as the phrase goes, "the farmer does not get his share of the consumer's dollar." Doubtless some statistics on this point are misleading; 


\section{2

unquestionably rural public opinion is narrow with respect to the real values created by middlemen; and probably distribution has been charged with failures that as a matter of fact are due to poor business manacrement on the part of farmers, or to competition between rival areas of production, or merely to the influence of the season's weather. Nevertheless there is ample ground for the assertion that the farmers are quite right in the main contention. Our system of distributing food products works in general against the farmers' interests. Wonderfully complete and effective in many ways as a system of carrying food from and into all corners of an immense country and into foreign lands, it is a system costly to run and built up with scant regard to the farmer's share.

3. The growth in tenant farming has become notable, especially in quite recent years. To a degree this was inevitable. A vast number of American farmers came into possession of their farms either by direct gift of the nation or at prices that were merely nominal. Ownership was made easy. There was small excuse for tenant farming. As soon, however, as the demand for land outran the supply of virgin soil, the landless farmers were compelled to rent in order to "get a start." No doubt a fair proportion of present day tenant farming is due simply to the fact that the farmer has to use this method of arriving at ownership - he is on the way to possession. But there are features of this movement toward tenantry that are very disturbing. It is in the main a transicnt form of tenant farming. Figrures gathered by the Census Bureau in 1910 showed that out of six and one-third million farmers, $1,787,473$ tenant farmers had been on the land they were tilling four years or less, and $1,123,722$ but one 
year or less. These figures are for both share and cash tenants. Now the evils of such a situation need no explanation. Poor farming is inevitable; soil depletion is unescapable; futile, ineffective lives of farmers and their families are unavoidable; and worst of all, the deterioration of rural communities becomes hopelessly certain. We have reached a point in American agriculture where it is worth while to hold land for its speculative rather than for its true economic value. In some of our most prosperous farming states land is slowly but surely passing into the hands of absentee landlords - not merely farmers who can afford to retire to the village or county seat, but to an increasing extent men whose main business is banking, mercantiling, or the law, and whose investment in farm land is purely speculative.

4. Perhaps the most menacing tendency in American agriculture is one that curiously enough attracts little attention among the farmers themselves. It may be expressed by saying that in some ways many of our richest farming districts are becoming our poorest. The prosperous farmer in his pride says, "I can afford to retire." Retiring means moving away from the farm. He has pulled out by the roots his leadership in his community. His support of local enterprise is no longer felt. If his place be taken by his son or other young man educated, interested, public-spirited, the case is not so bad. But as a rule his place is taken by a man of lesser capacity whose interest in community affairs is transient. The sense of community responsibility, the feeling of local patriotism, the pull and push of loyalty to the common good of the neighborhood has dried up as the rootage of personal attachment to the farming community has been exposed. 


\section{I4 THE FARMER AND THE NEW DAY}

As a consequence it is probable that the great fundamental social institutions such as the rural school and the country church are not merely relatively but actually less efficient than formerly in many parts of our country, even in regions in which land owners are very prosperous in a business way. In some cases these changes for the worse are so marked that we find that entire neighborhoods in the course of perhaps two decades become populated by a class clearly less effective, less intelligent, and less ambitious than was formerly the case.

Now this way lies the extinction of the "American farmer." If farm "prosperity" spells actual rural decline, the yeoman type of soil tiller is doomed. The new peasant will take the place of the old plowman. One may still view the whole picture of American agriculture with pride, but only the blind optimist can fail to see the menace of these and other similar tendencies in our rural affairs.

\section{WHAT THE WAR HAS REVEALED}

And then came the war. How it intensified our thought about the future welf are of our country! Absorbed as we were in our effort to win the war, down underneath our activity we kept pondering the question, What is the war to bring us as its great abiding results? And so in agriculture we ask, What has the war revealed?

I. "Food will win the war" was an exaggerated statement of a great fact. Never before in all our history has our sheer dependence upon the soil and the men who till the soil revealed itself to the multitudes who have never had a curious question as to where food comes from, much less as to the welfare or the people 
who grow it. The war surely brought the farmer to his own in respect to a new consciousness on the part of the world's food users of their utter dependence upon him.

2. The war revealed to the farmer more clearly his duty as a member of society. He has seen as never before his obligation to strain his back to even severer toil for the sake of those so dependent upon him. Heretofore he has naturally been more concerned with his rights - with getting a fair and just return for his labor. He has not felt a keen personal sense of obligation to supply food for people who can't grow it for themselves. Now the deepest parts of a nature rich in feeling have been touched. The farmer has been asked to produce, not primarily for profit but for a great cause. And has the farmer responded? Indeed he has responded. If America's part in the war is ever adequately written, one of the great chapters will tell of the way in which the farmers who stayed on the land, working under the greatest difficulties, met the "call to the colors."

3. But the war also revealed a vacant chair at the nation's council table - the chair of the farmer. (And here let us recall the writer of Ecclesiasticus.) The United States Department of Agriculture, with its great machinery and its staff of trained and able men; its auxiliaries, the agricultural colleges and schools; and particularly the new but effective system of county farm bureaus - verily raised up for the great hour - all have done an effective and indispensable service in the crisis. Groups of farmers have from time to time and to an increasing extent been in consultation with responsible officials of government and their counsel been made effective. Nevertheless 


\section{I6 THE FARMER AND THE NEW DAY}

the working farmers of America as a class have not been represe'nled in any authoritative or adequale way in the groups that haie outlined policies nor in the councils that have determined destinies, either with respect to agriculture itself, nor in those fields of effort in which the farmers as a great class of citizens have a special interest. This is not a new situation. The war has merely revealed it in an accentuated form. The farmer has never been taken into council about the big affairs of the nation in political, business or welfare enterprises. "How will it affect the farmer?" is a question seldom asked in a serious, intelligent way in those conferences in which great movements for human wellbeing are started and maintained.

4. Our entrance into the world war also revealed the absence of a national agricultural policy, clear, definite, accepted by the farmers. The war made clear once for all that the problem of food supply is one problem, and that a program of activities for the farmers must fit into a program not only for producing but also for distributing and using the food produced. We did not have at the opening of the war, and we do not yet have, a food supply policy on a national scale, unified in its program and fully coöperative in its methods, with all agencies working as one instrumentality in an effort to carry on one big task. Part by part we dereloped an agricultural policy for the war, but slowly, hesitatingly, partially. Our agricultural preparedness for the war was but little further advanced than was our military preparedness.

5. It is quite clear that both lack of agricultural representation in national affairs and absence of a distinct agricultural policy are in a very real way the farmer's own fault. The secret of the matter is the 
unorganized character of agriculture. "Farmers' organizations" there are, of considerable recognized power. Associated efforts there are by the thousand for various purposes. We have a huge and on the whole an effective scheme of publicly supported agricultural education. We have an alert agricultural press. But there is no national figure nor central group of men to voice authoritatively any message to or from the farmers. There is no one of the farmers to speak for the farmers. American agriculture, unlike other prime industries, is not organized. It is a great unwieldy, complex mass of individuals and relatively small groups, without effective unity of thought to direct or tongue to express.

6 . In the current discussions about the problem of "reconstruction," slight attention is being given to agriculture. An examination of many recent books about "democracy," "the new social order," "industrial democracy," "the new epoch " reveals an almost utter failure to sense the significance of the farmer's place in democracy in social and industrial re-formation. Agriculture is still the largest single industry in America however measured. It employs directly more men than any other industry. Do we desire social justice for our people? Nearly half of them live under rural conditions. Do we wish to reorganize our educational system in the interests of a "safer " democracy? Considerably more than a third of the children of the land are to be found in the "little red schoolhouse." Are we anxious lest the New Day will fail to give us a firmer grip on the spiritual and ideal aspects of our work and life? Probably forty million souls are either touched or untouched in the matter of religious values and motives by the country church. The declaration of the 


\section{IS THE FARMER AND THE NEW DAY}

British Labor Party, regarded by all true liberals as one of the great social documents of any period, is all but silent with respect to the rights and duties of farmers in the new social order. Yet the food problem of Great Britain is vital. Germany's aid to agriculture was the bed rock of her power to fight. If Russia is ever redeemed, it will be achieved through the education and organization of her peasantry, which constitutes more than seventy-five per cent. of her population. The Balkan states are nothing but rural provinces. China and India are largely rural.

\section{IS THE FARMER REALLY COMING TO HIS OWN?}

Thus the war has once more brought to the fore this age-old query. It has shown us in America particularly both the great, splendid strength and the serious, menacing weakness of our farming and our farm life. We must pause to discover whether the American farmer is moving upward in his place in society or gradually sinking in the scale. Is it to be easier or harder $f, r$ his sons to buy land and to make a fair profit from it, than it was for him or for his grandfather? Whither? This is the big question in our rural affairs. Is the farmer even holding his own? The American farmer has been a great exception to the century-old rule that "he that holdeth the plow ... shall not understand the covenant of judgment, nor be sought for in the council of the people." But in the New Day, in which we devoutly hope and fervently pray that we may have an end of economic serfdom, can we preserve this yeoman, this well-bred, highly intelligent, individually effective citizen, the American Farmer? 


\section{CHAPTER II}

\section{THE CHALLENGE OF THE NEW DAY}

THE Hebrews of Isaiah's time looked forward to a golden age with a new heaven and a new earth, when "Thy people also shall be all righteous: they shall inherit the land forever, the branch of my planting, the work of my hands, that I may be glorified. A little one shall become a thousand, and a small one a strong nation." Centuries later, with faith still high and gaze still eager, the seer beheld the holy city let down from heaven, and heard the promise that God would dwell with his people and would wipe away all tears from their eyes.

All through history the human mind has held to the ideal of a better day for mankind. The tragedy of the ages has been its postponement. But the hope never dies. It springs afresh with new opportunities and there is in each new effort some gain. The war stirred to its depths this spirit of a progress to be made in terms of human welfare and happiness. The Allies were forced to meet a huge and conscienceless effort on the part of an exceedingly strong people to achieve world power by force. But among the Allies themselves there were at the outset mixed motives. Ideas of imperialism unquestionably were ingrained in the minds of their statesmen until the United States entered the war. At that time came the great interpretation of the deep possibilities of the war - to "make 
the world safe for democracy." Like a flood the ageold ideals burst forth once more with new expressions of resolve.

So to-day there is a widespread hope that a New Day for mankind is about to dawn, yes, has dawned. Books without end are already written on the text that a New Day is upon us. Men are recasting their thinking, sceking to discover what all this means for them and for others. Groups of men and women are trying to write down on paper statements that will express their views of what gains we may make now that the war has ended.

Among all these efforts to express the real meaning of the New Day, the one that has attracted most attention is "the draft report on reconstruction," prepared by members of the British Labor Party. While radical in its spirit, it is notable alike for the breadth and scope of its ideas, for the sweeping character of its proposed methods, for the dignity and clearness of its style, and for the prospective political influence of its sponsors. The most significant words in this document and among the most important words of recent times are these: "We must ensure that what is presently to be built up is a new social order, based not on fighting but on fraternity - not on the competitive struggle for the means of bare life, but on deliberately planned coöperation in production and distribution for the benefit of all who participate by hand or by brain not on the utmost inequality of riches, but on a systematic approach towards a healthy equality of material circumstances for every person born into the world not on an enfored dominion over subiect nations, subject races, subject colonies, subject classes, or a subject sex, but in industry as well as in government, on that 
equal freedom, that general consciousness of consent, and that widest participation in power, both economic and political, which is characteristic of democracy."

Here is the slogan of the New Day - complete social reconstruction. Not a mending, patching, repairing process, but a rebuilding of human society, a true re-formation.

These words sound like the theories of dreamers, the visions of quiet students who have never had to hew their way in the world. No; they are the sober voice of wage earners, hand workers, millions of them, who look forward to a New Day for themselves and for others - not as a dream but as a goal to strive for at once. This gospel of the New Day was abroad before the war broke out. In our own land the fight against special privilege had taken on new vigor when Mr. Roosevelt as President threw his great personality into the struggle and announced his allegiance to the forces of public righteousness and business morality. The political Progressive movement was fundamentally a revolt against predatory wealth and the entrenched power of a few, and on behalf of the welfare of the many. But the war has driven the longing of the common people ahead a whole generation; it has given them a new power in big affairs; it has even obliterated national lines and shown that people the world over want the same thing - a New Day.

Our special interest lies in an answer to the question, What does the New Day mean for the people on the land, for the farmers of the world? Do they share the vision and can they help build the new society? To answer this question we must first try to discover 


\section{THE SPIRIT OF THE NEW DAY}

One approaches such a subject with caution, for each person who tries to understand for himself the meaning of the new time will, of course, come to a point of view a little different from that of any one else, and will moreover express his views somewhat differently. When one is dealing with so big a thing as the rebuilding of human society, it becomes almost foolish to prophesy. Great currents are sweeping us on. We cannot control them and we are not even sure where they are taking us. Their direction may change overnight; because for a long time after peace comes, human society will be subject to volcanic disturbances that may change the entire face of the earth. But even if we cannot tell just what is going to happen, we may with some measure of confidence describe the great hope and the great faith in the new spirit that will animate human affairs when once more the efforts of men can be used for construction instead of for destruction. There are at least four big items that seem to stand out as parts of the spirit of the New Day.

I. In General, a Far Betler Chance for the "Common Man." It is one of the strangest perversities of our human nature that the very thing that spurs us on to achievement may be the thing that becomes the greatest obstacle to true progress. The desire to advance, to achieve, is for all practical purposes an ambition to excel. One of the mainsprings of progress has been just the intense desire to excel others. We admire the driving power of such desire; we despise the person who "doesn't want to get ahead," who "lacks ambition." Yet this trait of ambition has led to preroga- 
tive, to privilege, to glorifying the power of the strong. It has classified the masses of humankind as the "common people" - presumably the others are the "uncommon people"!

Nobody really fails to understand that there are wide differences in the capacities of men. Some of us have had to discover with sorrow and keen regret that we must work under many limitations - limitations that some others do not seem to have. We have to submit to the fact that there are others abler and more competent than ourselves. This elementary lesson of life some people never learn. But even when the lesson is learned, our minds are not satisfied with a situation that still persists. After a time the abler people, the strong, so arranged affairs - not usually maliciously or even always consciously - but actually arrange affairs so that it becomes increasingly easy for the few to procure the things and the conditions that all people aspire to possess, and increasingly difficult for the many even to try to obtain them. The abler few apparently knew how to plan aluead. They are the organizers of schemes and programs. So long as the world goes forward on the basis of each man for himself, the strong push ahead. So we have developed leadership, statesmanship, even aristocracies. Sometimes these arrangements result from sheer ability, careless however of the interests of the many. More often they are the persistence of old privileges which possibly once were earned, but which have been passed on to those who had no part in deserving them. But the rest of us the common people - have grown more and more impatient of such arrangements. The great, fundamental, abiding promise of the New Day is that future arrangements among men, alike in respect to work, to 


\section{4 THE FARMER AND THE NEW DAY}

goverament, and to the conditions of living, will have regard primarily, not incidentally or accidentally, to the common man, to the great masses of men and women. They are to have in vastly enlarged measure the opporlunilies for comfort and happiness and rewarding labor and growth of mind and heart, that have to so great an extent been the privilege of the few.

2. Planning a Civilization. The very fact that the work of the world has been done on the basis of individual interest, has led to a certain measure of drifting or chance development. One might, of course, be led to make this statement too strong, for there has been a vast deal of planning. Perhaps the best single test of an efficient civilization is the ability of men and women to plan how they will work and live together; what their great objectives are to be and how they can best be attained. In the past this planning has been done largely by the few, and in the interests of the few. Plans for the many have as a whole been made without their assent, and not always in their interest. The spirit of the New Day will call for a better and bigger plan of work and life for all men in the interest of all alike.

3. Reconciling Efficiency and Freedom. The idea of efficiency has come to stay. Wasted effort, wasted resources, wasted time are immoral, " dead wrong." The spirit of the New Day demands from each person, from cach working group or class, from each social institution its utmost effectiveness and largest exercise of capacity. At this point, we are obliged to learn from Germany; to fail to do so would be foolish. For Germany, beyond any other nation, has learned to make a plan for the work and life of her people that 
makes their combined effort most effective toward whatever end or purpose she has in mind. The German plan fails to meet the test that will be imposed by an American, and in the long run the best interests of her own people, because the plans are made and executed for and not by the many. They are superimposed by supermen upon those below. The true democrat will not despise wise leadership - more of that later. But men will be free. There is a growing conviction among thoughtful people that perhaps the biggest single task of the New Day is to secure the full efficiency of men and peoples, while conserving their liberty, their initiative, their private power to think and plan and do.

4. Duties as well as Rights Are to be Emphasized and even Enforced. The common man has thus far made his fight for opportunity largely on the basis of justice. He has claimed that he has not had his "rights." He has antagonized the so-called "rights" of the privileged classes because he believed that these rights created great wrongs. Now the spirit of the New Day is a spirit of righteousness - rightness. It holds that the great test of all human endeavor is whether or not it is right. The moral not the economic method and result is after all the big thing. The struggle for the rights of the common man is therefore a legitimate struggle. If he cannot secure his rights, he cannot be free, and if he cannot be free, he cannot grow to the full stature of a man. Now the common people gladly receive this doctrine when it applies to their own rights. This is natural, for they feel and on the whole have a right to feel that their rights have been denied them. They believe that the struggle for their rights is a righteous struggle. 


\section{THE IARMER AND THE NEW DAY}

But the spirit of the New Day also demands that to insist upon rights alone is not enough. We all agree that to grant our own rights is the duty of other people, but we must appreciate the fact that the others have rights which it may be our duty to grant. It has been said by a wise American economist, Thomas N. Carver, that "my rights are your duties, and my duties are your rights." These two must then be married; they belong together by divine fiat. The spirit of the New Day, calmer than the spirit of battling men, insists that duty and right cannot be divided. They act and react upon each other. The fight for rights has an incomplete justification unless it is accompanied by a recognition of obligations. Not only so, but the spirit of the New Day urges that ultimately the victory for rights is fully won only by those who fulfill their duty. This is mercly a modern interpretation of the old truth that "he who would save his life must lose it"; "he that would be first among you, let him be your servant." The magic word "service" is the keystone in the arch of the new social structure. If each man, each class of workers, each country could contribute to the common good its full measure of service, the rights of them all would be safe.

The spirit of the New Day then seems to call for (I) a far better chance for the common man; (2) the intelligent planning of human progress; (3) a reconciliation between organized effectiveness in human work and life that also leaves individuals and classes truly free; (4) an insistence upon service to fellow men as the great motive in life, believing that thus social justice can best prevail. 
THE CHALLENGE TO THE FARMER

Do these great ideals call to the men who are on the land? If they do, how may they be interpreted in terms of the work and life of the people who farm? This interpretation makes a challenge to the mind and heart of every farmer. What is the challenge?

i. That the farmer's duty is to help feed and clothe the world. He is designated by society as the steward of the soil. He is the keeper of the land - the most precious material resource of humanity. He owns or controls the land on terms which society as a whole rightfully prescribes. He has no right to use the land merely for his own immediate benefit. He has no right to deplete its fertility; the land will be needed, sorely needed, ages after he has lived out his brief span. He did not put into the soil its nitrogen, nor its potash, nor its phosphoric acid. He does not make the rain the former and the latter rain, nor the sunshine and heat of summer, nor the busy bacteria which work among the grains of soil. He may plant, but God giveth the increase. He is merely God's tool, His human instrument, in feeding a hungry world. The farmer has a solemn, unescapable obligation to his fellow men - to use every acre under his control to its fullest safe capacity for producing food for those who cannot produce it for themselves.

2. That the farming group, like other groups, shall have a fair reward for its labor. The world has not as yet been able to decide what forms the basis for a "fair" reward. Heretofore reward has been largely a matter of taking what toll one can get as the goods or service pass through the hopper of personal or corporate control. Competition in efficiency, demand and 


\section{$2 S$ \\ THE FARMER AND THE NEW DAY}

supply have been the rough measures by which reward was finally determined. That this process will continue there is little doubt, but it will take on at least one new aspect. The quest for efficiency will not be left to the individual alone, but efficiency will be regarded as a social duty, a thing in which society as a whole is profoundly interested. How to make each man as efficient as he can be made, is going to be the great business of society. All the elements of efficiency - health, skill, intelligence, ambition, and incentive of reward - will be recognized. Furthermore, it will be found that efficiency must be defined. It is possible to have cheap goods made by cheap men. But men are of more consequence than materials. So with the farmer. He must make himself as efficient as possible. The best possible instrumentalities of education must be placed at his disposal by a society that is vitally interested in his efficiency. But society will insist also that the whole scheme of things shall be such that each farmer may have a decent living. If the farmers as a class cannot have a reasonable profit,.they cannot farm; and if they do not farm, society will not obtain the food it needs. We are not discussing just here the methods or amounts of rewards; we are simply trying to make clear that the permanent service of the farmer to society cannot be fulfilled unless he can be assured a reasonable income for his effort. He has a right to assert his right to a fair reward.

3. That the farmers, like other groups, must organize in order to meet world situations, but organize in such a way that the farmer as an individual retains his freedom. A plan for building up the business of agriculture must be dereloped. An agricultural policy and a definite program of operations must be evolved. 
There must be no longer a mere drift into activities. Statesmen must be made to see the significance of agriculture in the national economy and even in the mutual interchange of different nations. Adequate machinery of government must be made available for aid to the big agricultural enterprises. Collective action of farmers must replace the futile aims of single handed endeavor. Leaders, equal to every demand of the New Day, must spring from the loins of the farmers themselves.

4. That the farmer shall have his proper place in the new democratic society. But let it be understood that farmers cannot take their rightful place in national or in world councils unless they make the place for themselves. It is far from a mere matter of aggressiveness due to powerful group associations or wordy assertions. They must have something to contribute. The farmers must make clear to themselves what democracy really is, how they can best fit into it, what are their relations to the rest of society, what are their particular rights and their peculiar duties; they must be able to express all these things to themselves and to others.

These items then constitute the challenge to the farmer which comes out of the New Day: ( 1 ) That his task is to feed the world; (2) that in doing it he must have a fair profit; (3) that he must organize his forces both for his own interest and in society's interest; and (4) that he must have his due place in the new democracy. 


\section{CHAPTER III}

\section{THE RURAL PROBLEM}

IF, in a group of one hundred men and women, composed of leaders in rural affairs - officers in farmers' organizations, rural school supervisors, directors of agricultural experiment stations, deans of agricultural colleges, government agricultural officials - one were to ask each person the question, "What is the rural problem?" it is probable that there would be no uniformity of reply. Each answer would in a large measure be influenced by the particular work the individual had in hand, or special difficulties which he had encountered. A few years ago an official of high standing in the government said that the rural problem in America was "better farming." James J. Hill, a man of masterful mind, concluded apparently that to increase the production per acre was the main need of our farming.

There is, however, no one part of the rural question that overtops all others. Rural improvement consists of many elements, all closely bound together, each affecting and influenced by the others. We must try to see the rural problem as a whole. Some years ago in Ireland, Sir Horace Plunkett announced a slogan that helps us to see that the problem of the farmer is bigger than any one difficulty or need of improvement: "Beiter farming, better business, better living." It might be a little clearer though perhaps no stronger if 
it read, Better farm practice, better farm business, better farm life. Do we not find at least these three great classes of problems in every farming community in the land? The farmer must produce in the most skillful way, with the least possible expenditure for materials and labor, and with the aim of securing as large a yield of high grade products as possible. When he sells his products to buy his requirements, he confronts an entirely new set of problems. Then, even if he makes a fair profit out of his producing and his selling, what is the real gain unless he and his family can and do have a satisfying life as members of their neighborhood?

\section{A NEW APPROACH NECESSARY}

We have heretofore approached the farm business from the standpoint of production. We have been asked, What can farmers produce? We must face about and begin the discussion of problems with the query, What do consumers want? This will be a hard saying to many men, but it is the beginning of the new wisdom about our agriculture. We have said to farmers "Produce, produce, produce!" We have given away land by the million acres in order to stimulate production. Men purporting to speak for farmers have even said: "Why worry about the consumer? He will take care of himself. Let us take care of the farmer." Agricultural colleges have experimented and taught and advised concerning production. But for years past, any farmer would tell you that his big problem was not one of production, but of selling to advantage. The war has taught us that the task of the farmer is to grow food and other soil-grown materials for the rest of the people. The reasoning is plain. 
The farmer grows wheat. Why? To sell it, of course. To whom will he sell it? Always to the people who eat bread and who can't produce wheat. If the farmer does not produce enough, prices will be so high that consumers can't have what they need. If farmers produce too much, prices will be so low that farmers cannot afford to grow. If the world needs four billion bushels of wheat, the farmer's task is to produce exactly that amount, at as low a cost of production as possible, with a fair profit for his toil. This arrangement cannot be achieved completely in practice; but it is the big thing to try for. We must think then of farming as mainly an effort to supply the demand for food.

We now begin at the other end - the wrong end. But we must find out what the folks of the world want to eat, where they want it, in what form they want it and when they want it. The farmers must then undertake to meet these wants. In the New Day, the prime condition of the farmer's success consists in relating his work to the whole program of food supply. It is legitimate for him to try to chancre consumption; he may seck to persuade consumers to increase the use of certain products, to purchase the better and more expensive grades, to buy home grown products, etc. But the great currents of food demand determine the farmer's task. Of course, we must add to "food" all other products grown from the soil, including animal feeds such as hay and other forage; materials for clothing and other fibers such as cotton, wool, hemp and flax. Taken together, these other products represent a very considerable proportion of the agricultural industry. Hence for example, in 1914 , while the wheat crop of the United States was worth $\$ 878,680,000$, 
the cotton crop was worth $\$ 59$ I, I30,000 and the hay crop $\$ 546,492,400$.

\section{AN OUTLINE OF THE FOOD AND FEED PROBLEM ${ }^{1}$}

This necessity of relating the farmer's work to the food supply is so fundamental that it is worth while to take space to make an outline of the entire problem of food supply, in order that we may see the more clearly where the farmer's job begins and ends.

\section{THE FOOD AND FEED SUPPLY PROBLEM}

(FOR ANY REGION — LOCAL, STATE, COUNTRY OR WORLD) Food Requirements

Kinds and amounts of normal demand

Grain and grain products

Meat and meat products

Dairy products

Vegetables and vegetable products

Poultry and eggs

Fruits and nuts

Sea food

Food Resources

Land: Tilled; tillable but unimproved; wet, arid and cut over

Labor: Family; hired

Equipment: Buildings; machinery

Fertilizers: Commercial - kinds; amounts; sources barnyard

Food Production

Present

Human food - kinds and amounts

Grown

1 This outline is adapted from one made by Miss Lorian P. Jefferson from suggestions furnished by members of the staff of the Massachusetts Agricultural College together with a most admirable food supply chart prepared by the Fond Problem Committee of the Merchants Association of New York City. 


\section{THE FARMER AND THE NEW DAY}

Food Production - continued

Marketed

Purchased

Animal feed - kinds and amounts

Grown

Marketed

Purchased

Economic (desirable substitutions)

Kinds

Quantities

Nutritive values

Prices or costs

Suggested changes

Better farm management as to

Competing crops

Competing crop areas

Markets

Community organization

For production

For farm business

(I) Purchase

(2) Sale

For use of labor

For credit

Provision for sceds, fertilizers, machinery

Insurance facilities

Credit facilities

Legislation as to

Marketing

Land transfers

Leases

Protection of stock, etc., etc.

Economics of production

Food versus feed

Live stock versus grain, vegetables, etc.

Labor for agricultural production versus labor for industry 


\section{THE RURAL PROBLEM}

Transportation of food versus transportation of feed.

Food essentials versus non-essentials in agriculture

Comparative costs, by regions

Food Distribution

Exports and imports

Transportation agencies

Railroads

Ship lines

Trolley lines

Trucks

Express

Parcel post

Local food movements

Storage

Farm

Commercial

Household

Standardization of grades and packages

Collective preparation

Bargaining: Individual; collective

City marketing

Public markets

Prices: Determination; publication

Prevention of waste and spoilage

Assistance in markecing: Marketing agents; market news service

Inspection

Food Conservation

Commercial

Manufacture

Vegetable products

Meat products

Fish products

Fruit products

Culls, seconds, surplus

Wastes

Preparation

Bakeries 


\section{THE FARMER AND THE NEW DAY}

Food Conservation - continued

Delicatessen

Hotels and restaurants

Storage

Wastes

Variety .

Servings

Home and Commercial

Preservation

Canning

Drying

Pickling

Salting

Smoking

Home

Storage

Cellar

Pit

Pantry

Wastes

Table

Market

Farm

Diseases: Plant and animal

Pests: Insects and weeds

Wastes through

Rats and mice

Improper curing

Improper threshing

Careless handling

Shrinkage

Garden wastes

Skim milk wasted

Methods of control

Transportation

Faulty icing

Improper heating 
Poor care

Delays in transit

Overloading

Underloading

Duplication of delivery

Shrinkage in transit

Dining car service

Preparation

Storage

Servings

Food Use-Home and Hotel

Nutrition

Food requirements

Well selected diets

Modified diets

Desirable changes

Racial preferences

Household

Children

Meals for large groups

Hotels and restaurants

Public institutions

Camps, etc.

Diseases due to faulty diets

Standards

Suitability

Wholesomeness

Cleanliness

Purity

Labor involved

Relative cost

Marketing

Selection

Prices

Market news service

Storage and refrigeration

Preparation

Equipment 


\section{THE FARMER AND THE NEW DAY}

Food Use-Home and Hotel - continued

Cooking

Serving

Wastes

\section{THE FARMER'S PROBLEM}

This outline of the problem of the world's food supply gives us a starting point fron which to discover the problem of the farmer. He is the supplier of soil grown materials. There is no need for his labor unless his products are wanted and used. The difficulties, needs and possibilities of the farmer's occupation arise from his effort to supply the world's food and other materials immediately dependent upon the soil. Society needs things that can be secured only through the use of the soil. The man who uses the soil to meet this need is the farmer. If we could treat the farms of the world as one big farm, we would first discover the frond needs to be met by what the soil can produce. The fundamental question in agriculture is, "What special nceds, difficulties, and possibilities does the farmer face as he seeks to become most effective in this task of supplying the world's food?"

Before proceeding, it might be wise to state that in this book the words agriculture or farming are used to mean the industry or occupation of growing things from the soil, both plants and animals; country life or farm life includes the so-called social aspects of agriculture, that is, the things that affect the welfare of people that live together in the country, such as education, recreation, health; rural is used for the whole range of interests attached to farmers and farming as over against the city or urban interests.

It is not the purpose of this book to discuss the spe- 
cific methods by which the needs and difficulties of farmers may be met. While such a discussion is of the utmost practical importance, it must be left to another time or to another pen. The matter of most immediate consequence is to discover if possible what the farmer's problems are. We want first to map out, as it were, the geography of the farmer's job. It is recognized that a mere outline of the problem does not get us very far with respect to what might be called practical methods of farm improvement. Those practical methods, however, are pretty widely known among farmers and there are whole libraries written about them. What is more important just at this stage in the development of our American agriculture is, first of all, to get a picture of the entire problem, if we can, for the reason that heretofore nearly all discussions of agricultural questions have dealt with but a part of the problem. Usually emphasis is placed upon greater crops, or collective bargaining, or control of transportation by the government, as if these were the chief or even the sole methods of improvement, whereas we can advance agriculture only as we develop systematically and constantly all along the line. Moreover, the principal reason for writing this book is not to call attention to detailed methods of procedure, but to certain large principles that need to be applied in a statesmanlike fashion; details will follow. It is therefore hoped that this outline, fragmentary as it is, will serve its purpose in laying before the reader the breadth, the scope, and the significance of the farmer's problem.

These problems may be grouped somewhat as follows: 
I. THE PROBLEMS OF RURAL IMPROVEMENT

I. In methods of controlling the necessary forces and materials of production.

2. In farm practice, or the production of crops and animals.

3. In methods of farm management and farm business.

4. In methods of farm organization.

5. In farm life.

\section{SOME NECESSARY ADJUSTMENTS}

I. Among the farmers themselves.

2. Between the interests of farmers and others.

I. THE PROBLEM OF THE BETTER CONTROL OF THE NECESSARY FORCES AND MATERIALS FOR PRODUCTION

I. The Control of the Land Itself. Land ownership gives the most complete control. The retired farmer has less control than the owner who works his own farm. The absentee landlord has only a minimum of actual control. Land may be owned by the state and leased to the men who work it. We must learn very soon what on the whole is the best method of land control in order that both farmers and consumers may have the largest possible benefits.

2. Land Acquirement. Farmers in America formerly got their land from the government. This is no longer true to any large degree. It is coming to be difficult for the young farmer to acquire a farm. Only two solutions are apparent. One is for the government itself to purchase land and sell it to new owners individually or in colonies with liberal credit and easy 
payments; or for large groups to do the same thing, either as private corporations for gain or coöperative land societies.

3. Land Rental. Rental under right conditions may secure very effective use of the land. Tenant farming does not tend as a rule toward building up permanent farm community interests. Very short leases are disastrous both to farming and to country life. Permanent tenure can be made satisfactory only when the tenant is given a share in permanent improvements.

4. The Control of Capital. Need for capital in farming is rapidly increasing because of increased cost of land, need of land improvements by drainage, etc., larger need for machinery and other equipment, higher cost of labor. The farmer needs both long term credit and short term credit, the one for land purchase and permanent improvements, and the other in order to take advantage of better terms in securing his supply of seeds, fertilizer, feeds. Mercantile or store credit is very costly in interest and should be abolished. One difficulty in securing credit for farmers is that the American farmer is as a rule unwilling to become a party to a plan whereby the farmers of a community collectively become responsible for the debts of the individuals of the community. Farmers have collectively enormous assets which ought to be made available for each worthy member of the partnership.

5. Control of the Labor Supply. The farmer has to compete now-a-days with industry for his labor, in the matter of wages, housing, hours. One of the biggest problems of the future lies in answering such questions as how to keep labor employed throughout the year; hov to educate the laborer so that he becomes a skilled farmer; whether women in America will do 
more farm work than formerly; how to use boy labor without sacrifice of education; the relations of farmers to farm labor organizations; and how to encourage the farm laborer to become eventually a farm owner.

6. The Control of Materials and Power. Commercial interests have served the farmer reasonably well in supplying seeds, fertilizer, stock feeds, machinery, but only to a small extent in supplying power. The government will probably have to intervene in establishing a democratic use of water power for the making of electricity. Farmers, however, will need to coöperate much more freely than now in the purchase of power, as well as of their other supplies.

II. TIIE PROBLEM OF IMPROVEMENT OF FARM PRACTICE, OR THE PRODUCTION OF CROPS

\section{AND ANIMALS}

1. Improvement of the Soil. This means securing greater depth of soil; more complete friability; more adequate control of water in the soil; proper adaptation of special crops to special soils; prevention of plant food waste and erosion; and in general, the question of permanent fertility.

2. The Improzement of Crops, by getting the greatest possible yields; improving the quality and food or feed value; securing disease and drouth resistant varieties.

3. The Improrement of Animals in size, quality, temperament, healthiness, etc.

III. IMPROVEMENTS IN FARM MINAGEMENT AND FARM BUSINESS

r. The Purchase of Supplies. It is only by collective or coöperative purchase of supplies and equip- 
ment that farmers can get the best prices and terms. So long as the individual farmer buys his supplies at a disadvantage, he is economically handicapped.

2. Standardizing the Product. The greatest single difficulty which the individual farmer faces is due in part to the wide variety of crops grown in a given locality and to a great variation in quality. The remedy in general lies in inducing farm communities to produce fewer things, to produce those for which the region is particularly adapted, and then through cooperation, to secure proper grading, careful and honest packing, and wherever feasible, proper labeling.

3. In the Transportation of Products. Good roads and the motor truck will play a rapidly increasing part in initial transportation. Rural trolleys will help to a growing extent. The main dependence for standard crops is the railway system. One of the most important reforms is the adjustment of freight rates as between the long haul and the short haul in order that both the distant producer and the nearby farmer may both have substantial justice.

4. The Problem of Storage. The purpose of storage is to keep such part of the product as is not immediately necessary, until it is needed by the consumer. The farmer believes, and probably with reason, that those who control storage facilities exact unfair toll from the farmer. The difficulty lies less in dishonesty than in the fact that the whole system is purely a profit making affair. The storage system should be organized and controlled as primarily a method of relating supply and demand.

5. The Selling of Crops. In case of fruits, vegetables, and poultry products, producer and consumer may be brought together face to face in public or com- 


\section{THE FARMER AND THE NEW DAY}

munity markets where they may make their bargain. For most crops, the middleman is indispensable. He should not be abolished but redirected. We shall never have satisfactory methods of marketing farm products until we have a thoroughly organized group of producers, each group with its special product, dealing directly with well organized groups of consumers, or with well organized groups of middlemen whose activities are regulated by the government in the interests of both producers and consumers.

6. 'The Farmer's Interest in Manufacture and Care'. The conservation and processing of farm products has gone largely into the hands of commercial concerns. The farmer, however, has a moral obligation to eliminate all wastes on the farm itself. Community enterprises looking toward the manufacture or preservation of certain products, both for use in the community itself and as a business venture, will probably increase. There is a vast waste in double transportation; for example, wheat is shipped one thousand miles for milling and the flour is brought back to the farm region where the wheat was grown.

7. Protection and Insurance. The farmer wages a constant battle against insect pests, diseases of plants and animals, unfavorable natural conditions such as weeds, Hood, drouth, frost, wind, hail, fire. IVidespread cducation, mutual insurance and coöperative action seem to be the main solutions. One of the biggest problems of protection is whether it is possible to insure the farmers to some extent against loss due to inadequate knowledge of market conditions, such as spoilage in food producis, forcel sales of products due to lack of credit, and market gluts.

8. The Re-iniestment of Farm Profits is not as yet 
a burning question but is not unimportant. Why can not farmers utilize their surplus when they have it, for the building up of the community in which they live?

IV. THE PROBLEM OF THE ORGANIZATION OF THE FARM

I. The Farm and its Equipment. It would be very helpful to have a standardization of farms on the basis of the most economic type and size of farm and the amount of capital and equipment in stock and machinery needed to operate the farm to best advantage.

2. The Permanent Improvement of the Farm. How can the farmer best secure a gradual improvement of his stock, complete a system of under drainage, provide economic but adequate and convenient buildings, and utilize labor-saving devices?

3. Bookkecping and Accounting. There is great need of adequate records and accounts simplified so that the average farmer can follow the plan. There are really two problems, one that of accurate business accounts and the other that of proper records which when interpreted will help the farmer to adjust his methods of management to the securing of greater economies of time and labor.

4. The Use of Labor. How may labor be secured at any price and how retained? One of the big questions is how to employ during the winter months farm labor needed only during the growing season, in order that labor may be satisfied and be available more continuously for the farmer. 


\section{THE FARMER AND THE NEW DAY}

\section{THE IMPROVEMENT OF FARM LIFE}

Means of Communication. It has been said that the problem of the city is congestion and the problem of the country isolation. In the city there are too many people to the square mile; in the country there are too few. Rural free mail delivery, the rural telephone, the rural trolley, to a degree, and the automobile have quite changed the aspect of country life. The problem is not yet solved, however, the greatest difficulty being that of getting and maintaining at reasonable expense a complete system of good highways, that reaches practically every farmer. The success of the consolidated school and of the community church, as well as economical transportation of farm products, hinge on this issue.

Home-making. The farm home is intimately attached to farm work. It must contribute to the profit of the farm, to the physical efficiency of the members of the family, to the most complete training of the children in character and citizenship, and make itself felt in the upbuilding of a satisfying community. The farmhouse should be convenient and beautiful within and without. It is possible to develop a system of home management that will reduce drudgery and encourage the life of the mind and the spirit.

Means of Education. We must make sure that the rural school gives the country boy and girl just as good an education for life either in country or in city as is given to the city boy and girl. Morcover, the country school should contribute more completely to the education of the adults of the community. Ideally, the people of the community will stay in school all through life. We must maintain a system of agricultural education, 
through schools and colleges and experiment stations and extension service and farm bureaus, that will reach effectively and practically the entire farm population. We should develop the habit of reading and study with a better system of rural public libraries. Continuation schools must be provided for the boys and girls who are no longer all the time in school, but who ought to keep up their schooling much longer than they do. And in general, we must stimulate the masses of farmers to closer study not only of their own problems, but of the problems of the New Day.

Rural Government. How can we make local government more efficient, more honest? Probably we can do more for the people of the community through the local machinery of government. We already support schools and build roads. Can we not furnish other facilities of community life? Can we not make legislation, both in state and nation, more in keeping with the needs of rural improvement?

Health and Sanitalion. We need a large program of education for farm people, especially those in less prosperous regions, in the full meaning of personal hygiene, the very best care of the body, the very best dietaries, and in public health, in order to stamp out epidemics, secure care of sewage, restrict the spread of contagious diseases. In many ways these things are much more difficult to handle in the country than in the city.

Recreation. This is one of the great lacks of country life. We need a more adequate play life for the young and a thoroughly satisfying social life for the adults. We must bring into the country some of those legitimate opportunities for pleasure that people of the 


\section{THE IARMER AND THE NEW DAY}

city have. Better than this, we would encourage the country people themselves in the making of their own recreation.

Country Planning. The roads, the buildings, the village parks, all of the material arrangements of the country, should be carefully planned.

Social Welfare. There is need in the country as well as in the city for helpfulness to those not well circumstanced; the insane, the feeble-minded, the poor, the sick, the unfortunate. We can organize better than we have thus far the spirit of helpfulness. It is not enough that we have the neighborly interest; we must also have the skilled aid.

Morals and Religion. How can we maintain the highest and finest ideals of personal character and of community life? How can we make religion real in the work of the farm and in the living together of the people? How can we assist the country church, the Y. M. C. A., the Sunday School, to be of the largest possible service in the country?

\section{SOME ECONOMIC ADJUSTMENT}

We have outlined the problem of rural improvement in a most sketchy way but we have not yet quite told the whole story. All that has gone before calls for a certain balancing of interests. There are adjustments to be made from time to time. There are diverse interests that have to be reconciled. We never can "solve" the farm problems as problems of arithmetic can be solved. In our search for constant improvement, we find the constant need of establishing new relationships by the people, of developing new methods of doing business. What is right and fair at one time may not be right and fair at another time because of changing 
conditions. So let us consider for a moment some of these adjustments that the farmers must recognize.

\section{ADJUSTMENTS AMONG THE FARMERS THEMSELVES}

We must secure a sort of balance between the interests of the individual and the interests of the farmers as a whole. This, of course, is a need everywhere in the world. It is not by any means true that if each individual is left to follow his own interests the interests of all will be gained. This is simply the "law of the jungle"; the strong win, the interests of the weak are over-ridden. Perhaps the greatest obstacle to agricultural business coöperation in America is the fact that the most prosperous and efficient farmers in the community do not see the need of pooling their interests; they are not willing to sacrifice a little for the sake of those who would be greatly helped by common action.

Balance between Sub-Industries. When a new opportunity in agriculture shows itself, it may become so popular as to crowd out other forms of production which are fully as essential. Fruit growing in the irrigated districts of the West not only encroached upon fruit growing in the Last, but hindered the development of dairy and stock farming to which the irrigated areas are peculiarly adapted.

Balance between Sectional Interests. One of the most serious of all rural questions is the competition of regions. The apple growers of New England with those of the Pacific Northwest; the vegetable growers of Florida with those of Massachusetts; the sugar beet growers and the sugar cane growers; the farmers who grow cattle feed in the Middle West and the dairymen of the East who have to buy these feeds. We find here constant need of establishing fair relationships. 


\section{THE FARMER AND THE NEW DAY}

Regional Self-Support. It is a law of economics that the greatest efficiency in production comes when each region produces that which it can best grow, not necessarily that which it can grow better than some other region. Each acre of land should be put to the best use for which it is fitted, considering soil, climate, labor, and market. Therefore it is neither practicable nor desirable that each country, or each state, or each county, or each community, should grow all that it consumes. But we have gone so far in producing for the distant market that we have not only neglected the nearby market which is often poorly supplied, but we have incurred an enormous expense for transporting and handling products which go back and forth. We need to establish certain zones or regions that up to a certain point can take care of themselves with reference to the growing of their food.

The Rural Village. There are perhaps ten million people in America living in villages that are set in a rural environment. The people are not farmers but they live in the midst of farmers. They are not city people. Their very existence depends upon the success of the farming regions around about, and yet there is often the sharpest antagonism between people of the village and the people of the country. The farmers believe that the village merchants exploit them at every opportunity. There is an odd notion among the merchants that in some way the farmers owe them a living. This antagonism shows itself in lack of social intercourse, in sharp political fights. How can we restore the balance between the village, which includes the small "city" set in an agricultural region, and the farmers round about? Surely there is a way toward 
coöperation, a real community interest. Each can help the other.

Permanent Agriculture without Caste. We have a shifting agriculturai population. There is scarcely any part of America which has not suffered from overfrequent migration to the city or to other parts of the country. Ownership changes frequently. This impermanence is not true everywhere, but it is characteristic of American agriculture. It cannot result in the best farming. It has not contributed to the best community life. Leadership is lost; yet we would not want everybody born in the country to stay in the country. The idea of keeping all the farm boys on the farm is the poorest policy we could follow. We cannot afford to arrange our rural education so that the boy is obliged to stay on the farm or go to the city handicapped in his preparation for life. The door from country to city must swing wide. There must be freedom of intercourse between city and country. We must not have a peasantry - a rustic group. In no parts of our country must there be a possibility of farmers being looked down upon or being sharply distinguished from other classes in any way that marks them off as a caste. How then may we adjust our modes of living, our education, our country life, our village life, so that we shall secure the advantages of permanent occupation of the land without the disadvantages of a caste system?

Some Special Problems. There is no doubt but the racial problems which have disturbed our country show themselves in agriculture. Special groups, such as the negro farmer, the mountaineer - able but isolated, the emigrant farmer - sturdy but foreign, must in some fashion be taken into the common lot. Only so can ive 


\section{THE FARMER AND THE NEW DAY}

have a real democracy. How are we to do it? There is the question of grades or strata of farmers. In almost any farm community we find a group of very prosperous and successful farmers, men who we say can "take care of themselves." Near the other end of the scale we find the "submerged tenth," men not very efficient. At the extreme end we find the hundredth man - the abandoned farmer. Between these extremes, the great group of average farmers. So we have farmers small and farmers large; farmers wise and farmers foolish: farmers educated and farmers illiterate; and we find the need of adjusting our ideas and our methods of living together so that as far as possible these walls of separation may be broken down. The problem becomes a very interesting and acute one in any farm community when we note the prejudices in church or in secret societies, and how certain groups are inevitably excluded. IVe also find farmers with special difficulties; the man with the tiny farm, the landless farmer, the laborless farmer, the farmer without capital, the farmer in the depleted rural community who would like to see a better day but is not hopeful that it can be brought about, and finally the farm laborer. Sometimes these matters do not seem like "problems"; but are rather taken for granted. They are important questions, nevertheless.

ADJUSTMENTS BETWEEN THE FARMER AND OTHER INTERESTS

The Balance between Producers and Consumers. We have had a great outcry because in some prosperous agricultural regions as well as in those less prosperous, the farm population has actually declined. At the bottom this change of population was simply an effort to 
adjust the number of producers to the number of consumers. Our land policy had developed too many producers. The application of scientific principles to production and the establishment of a nation-wide system of transportation enabled relatively fewer men to grow the food of the nation. But of course this may be carried too far. If we have too many producers, we get cheap food and also cheap men on the farm. If we have too few producers, the country is not adequately supplied with food.

Adjustment in the Factors of Production. The problem is essentially this: How may the farmer compete with manufacturing and business interests for land, labor and capital? It is a question of proper relationships. The farmer must have his share of these or he cannot do his best work. He has to compete constantly with these other industries. How can we make sure that he has a fair field?

Yield per Acre and Yield per Man. The strength of European agriculture lies in its large yield per acre of land. The strength of American agriculture lies in its large yield per man who works the soil. It is in the interests of consumers to have the maximum yield of food per acre; it is in the interests of producers to have the maximum return due each individual worker. But clearly, both of these things cannot happen at the same time. Somewhere we must find the fair balance. We must adjust the interests of both. How can we do it?

The Conservation of Soil Resources. Less than formerly do the farmers want to use their land even if they use it all up. It is a truism that the American farmer has skimmed the cream off the soil and then gone on west. Society, that is all of us together, which really owns the land, is interested to have it become more pro- 


\section{THE FARMER AND THE NEW DAY}

ductive, whereas it has become less productive in many regions. Of course the good farmer has the same interest in keeping up production, but many farmers do not see it. They want immediate results. Clearly we need an adjustment that results both in that use of the land which gives a fair return to the farmer, and that use which preserves its fertility undiminished for future generations.

Sharing the Savings. Both farmers and consumers would like to abolish the middleman's profits. The farmer rather expects to get most of the profits which the middleman has made, and the consumer, oddly enough, has the same ambition. Both cannot succeed. This tendency shows itself in a public market where householders buy of farmers. Each wants to get the best bargain possible. What eventually happens is probably a pretty fair trade, both getting some advantage in this matter. This principle holds in the whole field of soil distribution. If economies of distribution are effected, who is to get the bencfit - consumer or producer? Both! It is a matter of adjustment. The answer lies in establishing fair trade.

Agriculture and Other Business. Agriculture is our greatest business and yet it is often left out of account in plans for possible development. But its relation to manufacturing, to transportation, to commerce and even to finance is very close and even vital. Imagine if you can the farm lands of America lying unproductive for a single year. Moreover, it is clear that if these relationships of agriculture to other industries are so close, competing interests will show themselves. Inasmuch as these industries are well organized and agriculture is poorly organized, the farmers are apt to be the 
losers. How can we adjust these big interests of these big industries so that all shall have the square deal?

Agrarian Legislation. The farmer has an interest in taxation, in the tariff, in currency legislation. It is believed that legislators have a tendency to ignore this interest, but it cannot safely be ignored. If it results in too great injustice, then we have a radical movement which smashes its way through, perhaps to undesirable ends for all concerned. What we need, then, is an attempt to adjust, in all legislative matters, the fair interests of farmers to the fair interests of other people.

The Farmer in Politics. How can the farmers make themselves felt in our political life? As a party, shall they have representation in legislative business, somewhat equivalent to their numerical strength? Neither of these things seems very practicable, perhaps not even desirable. On the other hand, are the farmers to be left out of account and have nothing to say? Are they to have no unified opinion or desire that finds expression through the political party or the government? How can we find the balance between political neglect of the farmers and political revolution among the farmers?

The Farmers and Organized Labor. Have these groups interests in common or are they absolutely antagonistic? If in common, where do these interests lie? If antagonistic, how may antagonism be allayed?

Rural and Urban Aspects of Civilization. There are people who think that the city stands for civilization, that leadership, wealth, organization, power, will reside in the city and take the helm of society's progress. But have the farmers nothing to contribute? Are not their methods of living and of thinking worth some- 


\section{THE FARMER AND THIE NEW DAY}

thing to the common country? One of the most important adjustments is to make it possible for organized farmers in every country in the world to make their fullest contribution in work, in thought, in ideals, to the common welfare of mankind. 


\section{CHAPTER IV}

\section{FARM PROFITS AND RURAL WELFARE}

THERE is one part of the rural problem that deserves further consideration at this point. As explained in the last chapter, it is not the purpose of this book to discuss the details of specific problems of farmers. But there is one aspect of the large general rural question that is of such vital consequence and yet is so seriously neglected in most plans for rural advancement, or even deliberately ignored as of relatively slight importance, that we must endeavor to bring it into its rightful place as a big phase of the relation of the farmer to the New Day. It is the "farm life" question. It has to do with the really human side, the true welfare aspect of agriculture. It may be called "The Country Life Problem." It is of sufficient significance in rural affairs to require our best thought and most ardent effort.

The tendency to neglect or ignore this problem is well illustrated in the remark that one hears so frequently as to be most exasperating and disheartening: "Show the farmers how to make money and these other things will take care of themselves." By "these other things," often mentioned in a half-contemptuous way, are meant such matters as the health, the play, the reading, the morals, the religion, the politics of farm people. They are supposed to be minor interests the real practical, man-size task is to tell the farmers 


\section{$5^{8}$ THE FARMER AND THE NEW DAY}

how they can make a profit, and then it will be time cnough to talk about the "frills" - indeed these lesser difficulties will find their solution in the mere fact that farm people, having more money to spend, will spend it for better churches and schools. We hear this sort of advice not only from some farmers, but unfortunately more frequently from official leaders of farmers, even from agricultural college professors. It needs sharply to be challenged. It is barely even a half truth, and it is working great damage to the best interests of the American farmer.

Another mischievous doctrine, somewhat akin to the other, asserts that country people are "just like other folks." Of course, they are. The statement is absolutely true, if by it we mean that American farmers are not a special class or caste, to be set off by themselves, with peculiar methods of living and with unique needs. But it is untrue if it implies that the rural environment has little or no influence and that there is no such thing as the rural mind or point of view, or if it leads us to act upon the idea that the plans and methods successful in city work can be bodily transferred to the country. That idea has done much harm. It has spoiled many efforts at rural school improvement. It has retarded a statesmanlike attack on the country church problem. It has perhaps kept the government from attending as it should to the needs of the country.

\section{THE FARMER'S VIEW}

When the Roosevelt Country Life Commission ten years ago set out upon its journey for information, there was at the outset in some parts of the country a good deal of resentment expressed because the very existence of the commission seemed to imply the need of "up- 
lift" for an ignorant, helpless and downtrodden class. In some instances even, resolutions of denouncement were passed by farmers' associations. The report of the Commission showed that its members had no such conception of the situation. But the feeling just described has persisted to such an extent that where an effort is made to study, discuss, or improve farm life conditions, there are those who cry "uplift," and the effort is at once thereby condemned. There is without doubt some basis for resentment against rural "slumming." There have been for many years past wild statements about rural decadence, especially in the eastern part of the country. Men and women from the city, with good intentions but with an inadequate background of knowledge or experience in rural affairs, have made "first-hand studies" of local farming regions, and from the very superficial material gathered have reached broad conclusions, almost always inaccurate, regarding the country life problem as a whole. In some instances there has been a tendency to investigate rural regions in merely curious fashion. Not seldom earnest efforts to help, where help was really needed, have been given with such obvious condescension and tactlessness that all has gone for naught.

As a matter of fact the most thoughtful and farsighted farmers have never failed to sense the significance of the human side of agriculture. The Grange, which is the oldest, the most broadly conceived, the best organized, and on the whole probably the most successful of the great farmers' organizations, has always stood four-square for what we now call the social aspect of the farm problem. In its famous "Declaration of Purpose," promulgated in 1873 , it puts first among its purposes "To develop a better and higher manhood 


\section{THE FARMER AND THE NEW DAY}

and womanhood among ourselves. To enhance the comforts and attractions of our homes." From the first, women were admitted to membership and to a share in responsibility. The "lecture hour" of each Grange meeting is intended for education and recreation. The broad social purpose and work of the Grange have been conspicuous. The fraternal idea has been strong. The Grange has for half a century consistently followed these great principles of rural welfare and it would be impossible to persuade any responsible Grange body to take the position that we can afford to neglect or to leave to chance the problem of a nobler womanhood and a higher manhood. To do so would be to repudiate the organization and all its works.

\section{BAD SOCIAL CONDITIONS DO EXIST}

If we face facts, we shall soon find that there is ample cause for alarm with respect to rural life conditions. We can easily find rural areas so isolated that loneliness reigns supreme, with the attendant evils of constant drudgery, unrelieved monotony, even of insanity and other forms of decadence. There are farm homes almost completely lacking in comfort, convenience, or even in the mere elements of refinement. There are rural schools of a half-dozen pupils, housed in an unkempt box of a building, taught by a half-trained teacher who is paid most meager wages. In some cases the amount as well as the quality of the schooling is pitifully inadequate. There are farmers who rarely take any recreation or permit their children to have it. There are places where the generally accepted rules of public health are unknown or unenforced, even places where common decencies are not observed. There are 
regions that never heard of efforts to make the country home beautiful or convenient, much less the country landscape and the community buildings. There are areas of child neglect and abuse, of immorality and even of crime. There are neighborhoods of the weak, futile, competing, even quarreling churches, where it seems apparent that if God has not forsaken them, they have repudiated $\mathrm{Him}$.

We may not say that these facts are isolated and therefore not characteristic, for they exist far too frequently; nor call attention to the great multitude of instances where precisely opposite conditions prevail, for you can't drain a swamp merely by looking at a three-ton field of growing meadow. We may not say that the cities are worse; it is slight gain for the "veterinary" to try to comfort Smith for his sick horse by telling him that Jones has a better horse that is sicker. We may not call it a slander to tell the truth; a boil can't be cured by pretending that it is merely a wart. We would best admit that such things exist and that they are a menace. We have often been shortsighted with respect to them, because they are not all true of any one region, because there are so many instances of better things, because in some cases we are ignorant of their existence, and also, sometimes because we accept them as a part of the situation and not as a challenge to improvement. We must not blame the alert social worker from the city, where matters of this sort have been the subject of close study and of intensive effort toward relief, if when he gets his nose into the country cellar he reports odors that he doesn't approve. 


\section{THE FARMER AND THE NEW DAY}

\section{ALWAYS ROOM FOR IMTROVEAENT}

But to win our case for the importance of improving country life, it is not necessary to dwell at length on the great defects. We can fall back upon the general proposition that there is no farm community so good that it cannot be better. We can challenge with the assertion that "the best is none too good." If there is one thing in the community that is not what it ought to be, let us make it right. If there is one family in the neighborhood that can be aided by intelligent sympathy into a better way of living, shall it not be done? IThy worry about the effects of well-meaning city people or organizations, so long as we can, out of our own observations and ambitions, find a way tovard the betterment of our farm life?

\section{THE CONCERN OF THE CITY}

It is often said that such matters as we have been mentioning are not the concern of the city anyhow and that urban discussion of country life is impertinent. But that is not correct. The war has taught us once and for all that no nation liveth or dicth unto itself alone. America now has a deep interest in every corner of the earth. And so at home, we cannot enter the New Day fully prepared to meet its problems unless we are conscious that the problems of New York's East Side have a meaning for the farmers of the wheat belt ; and that the quality of farm life in every remote county of the land must have its bearing on the interests of the great city. There is a stream of human life constantly flowing from country to city; is it pure and wholesome or muddy and defiled? The answer is of vast concern to the city. A careless dairyman up in 
the hills may be the cause of a great epidemic of disease in the city. The intelligence in political affairs, the education, the morals, the general welfare of forty million rural folk are of prime consequence in our national welfare.

\section{BUT IS THE CONTENTION REALLY SOUND?}

We have been dwelling upon the importance of facing the facts of country life, and upon the views of farmers about rural welfare itself. Let us now see just why, as a piece of argument, the doctrine that country life will take care of itself, provided the farmer makes a profit out of his business, is fundamentally unsound. What are the main objections to the statement? Chiefly that it isn't true at all, as usually put, and even contradicts itself. This purely business conception of the farm problem narrows the farm question, ignoring its most vital part, the real end of all human endeavor. Moreover, the idea, allowed to go unchecked, deprives us of some of the strongest helps we have for farmers struggling to win a fair monetary reward for their hard toil.

It will be admitted that a condition of reasonable prosperity among the overwhelming majority of farmers is absolutely essential for any adequate kind of farm life. To assert anything else is sheer folly. The country preacher, teacher or social worker should not for one moment forget that a sound rural civilization must have for its foundation a bedrock of decent money income, a fair reward for toil. A good community life costs money. To supply good rural institutions costs money. But the converse is also true: That a prosperous farm business is not all of the farm problem; indeed, the desire for a satisfying life is often the 


\section{THE FARMER AND THE NEW DAY}

fundamental cause of financial profit; a sound rural civilization must also have as secure foundation intelligence, morality, ideals of personal and community life.

The "economic motive" - that is, the desire for gain - is very powerful with us all, but it is not the only motive. Love of home and children, patriotism, religious faith, all have their part in stirring men to their utmost endeavor. The high-minded farmer never works merely for profit; he wishes a reasonable income in order that he may educate his family as well as himself into a satisfying kind of life. He will deliberately choose for his home, of two communities of equally fertile soil, the one that gives better promise of good schools and churches and neighborhood life.

Nor is a good farm life wholly dependent upon profit, certainly not upon large profits. The beautiful family life, the honesty and honor, the loyalty and the religious faith of Robert Burns' cotter have been repeated in all essential respects in tens of thousands of rural homes that enjoyed only a meager income, not only among the rugged Scotch farmers but wherever the ideals of true religion have prevailed.

While it is true that some of the community improvements we most desire can come only as a result of material prosperity, this is often but an excuse for failure to improve. One strong active alert country church would not cost a community as much as a half-dozen small struggling competing churchlets. Books and periodicals, the habits of reading and of study, keenness of minds open to new ideas, the desire to try new ways, - these things don't wait for money - indeed they are the conditions of financial gain, rather than its results - more of that in a moment. 
But the most alluring and the most dangerous aspect of this general statement about "these things taking care of themselves " is the idea that once a region becomes prosperous, then automatically the people themselves see to it that living conditions are improved in proportion. Once more we may admit that a poverty-stricken country simply cannot support a good farm life. But the facts are that a rich country also often fails to support a good farm life. Why do so many "well-to-do" farmers move to "town"? As a rule in order to have living advantages that they do not have in the country. The very profits that should go into improving local conditions go to rob the farm community. There are whole regions where the individual farmers have grown rich and the farm life in the community where they made their wealth has grown poorer. Is it not strange also, that we must devise laws, and organizations, and systems of education to help the farmer make a profit out of his business, but that we don't need to help him in those matters of home and community "uplift" because they "will take care of themselves"? Why not let profit take care of itself? Surely every farmer wants a profit.

The economist, who is supposed not to be sentimental, but who is obliged to weigh the motives that lead to wealth production, tells us that when men begin to secure more than a bare subsistence, what they want is likely to be the measure of what they get. "Greater profits in agriculture depend upon standards or prospective standards of living and comfort." If a farmer has an automobile ambition instead of a buggy ambition, he makes his farm yield enough profit to enable him to buy an automobile. The desire for a piano is a stimulus to make the old farm buy a piano. If a com- 


\section{THE FARMER AND THE NEW DAY}

munity wants a good schoolhouse, it gets it and pays for it because the farms of the region are made to pay better - partly at least on account of the wish of the people to have a better schoolhouse. We cannot be sure of all the reasons why we work harder than we otherwise might, but we do know that the increase of our desires stimulates us to greater and more effective toil. So that once more we find that the desire for "these other things" - education and recreation and good houses and books and reading and better churches — is really a wonderful stimulus to better farming. For farmers, like other people, do not work for money only for what money will buy. What farmers want for their labor is not really profit - but the things and the experiences that their profits will get for them and their families.

Worst of all, the doctrine we are endeavoring to combat strikes at the root of a really sane wholesome view of human life itself and tends to substitute means for ends. What does it profit a man if he gain the whole world and lose his own soul? What is the gain in bigger barns if the man's life is required of him on the morrow? Shall we never, never learn the lesson? A man's work, yes even profit, is only a means to an end, and the end is - life. So with farming. Shall the farmer plow and sow and reap and gather into barns; toil early and toil late, sweat and strain, and go with gnarled fingers and bent shoulders, merely that he may wring a few more dollars out of it all? No; the end and purpose of "better farm practice" and of "better farm business" is a "better farm life." If we don't get that soe fail! Let us not forget this truth. We must not, cannot disregard the means to 
this great end; we must have better farming and better business. We must help the farmer here at every turn. But it is all done in order that out of it shall come the sort of farm life that the farmer deserves and that the nation wants him to have, for its own sake as well as for his.

\section{THE PRACTICAL ASPECT}

On the practical side, too, there is great harm done by the statement that "these things will take care of themselves "! It works to prevent due study of country life affairs, the fostering of rural agencies for social advancement, and especially does it tend to narrow interests and restricted views of the farm question. It keeps us from seeing the rural problem with two eyes. It discredits the work of teacher and preacher and social worker. It makes possible a wrong definition of "practical." For a book could be written proving that even in the effort to obtain greater profit the intangible "spiritual" things are the most effective. Here are two farmers on adjoining farms. One succeeds, the other fails. Why? Both are equally "helped." Both belong to the Grange, can receive the same agricultural bulletins from Washington and from the state experiment station, can attend the same extension school, belong to the same farm land bank, participate in the same farmers' exchange. What is the explanation? They are different men; that is all. Now unless you believe that men cannot be improved, then you must admit that the thing to do with the failure is not to give him more helps toward profit, but to awaken him as a man. And you can best awaken him as a man only when you have touched the springs of character, 
have brought him to see his whole life in a new light. Perhaps he disregards ordinary rules of hygiene, and loses days and weeks of labor and time. Perhaps he works so hard he hasn't time to think, and no plans develop. Perhaps he just lacks the stimuli to thinking that come from neighborhood contacts. The man-especially the young man - gets these stimuli in school, in church, in Grange, in sociable life, in books and reading - all social realities. It is these that shape his life and make him an efficient worker - not at all the mere quest for profit as a thing by itself.

There is one more thing that needs to be said. Our American farming suffers from its transitory character. We do not want upon the land a peasant caste - a class out of which it is difficult to rise. But we do want a permanent agriculture, and we can't have a permanent agriculture unless the farmers love farm life as well as make a profit out of the farm business.

\section{WHAT THEN IS THE TRUTH?}

What we need is a true balance of forces, motives, and methods. Ideals alone produce visionaries; work for gain alone brings barrenness of real life. We need both. We need emphasis in rural affairs both upon the economic issue and the social problem. They should have equal attention for they are at least of equal importance. One cannot go ahead at full speed without the other. They must be driven double and not tandem. Let us give full measure of effort to the making of American agriculture more prosperous for the average farmer; but let us also cherish with equal endeavor and intelligence his highest, truest welfare. Let us learn that there is a place for the work of experts in farm life as well as in farm practice or farm 


\section{FARM PROFITS AND WELFARE}

business. Let us develop the agencies of country life, such as school and church, with as much zeal and earnestness as we devote to increasing production and securing better prices. 


\section{CHAPTER V}

\section{FARMING THAT IS NOT FARMING}

THERE has been developed in America, gradually but very steadily, an interest in the soil that is not farming in the older or ordinary sense of the word. It might be called the "twilight zone" between farm and city. It has to do with the food production in some measure, but its greatest significance arises from quite other aspects and influences. Heretofore this twilight zone has not been of very much interest to the farmer. Indeed he has been inclined to treat it as something of a joke. He has enjoyed the thought of the city dweller fussing with a few vegetables and calling it farming. In a few cases where it has become a factor in production, the farmer has perhaps been moved to oppose it. But the war has brought out in a stronger light this new interest. The "war gardens" have grown apace. There have been millions of them. Now that the war is over, most of them will be discontinued, but many will persist, and some aspects of these war ventures will become important. In fact, we must recognize that in this twilight zone there is a very important field of effort in which the soil plays a large part. The farmer ought to be sympathetic toward it. He can afford on the whole to ignore the question of its effect on the prices of his products, because its influence is not likely to be very detrimental to him, while its development means so much for humanity that it ought to en- 
list his sympathy. At any rate, it is probably inevitable, and even if the farmer's business is affected, he will probably have to adjust his mind and plans thereto.

We must not confuse this new field with what has been called the "back to the farm " movement. There are still some who believe that our agricultural problem is to be solved by a return migration from city to farm. This twilight zone of farming does not at all solve the farm problem; perhaps it complicates it. It may help mightily to solve the city problem, for looking at it in the large way, it promises not so much an economic gain for humanity as the evolution of a great welfare movement. It is likely to become a real asset in improved methods of living. It consists of a rather miscellaneous group of activities. At present, it is more in evidence in the East where the population is crowded, but it arises wherever there are large cities with huge factories and crowded living conditions. Let us recite quite briefly some of the items in this twilight zone of farming that is not farming.

The Five-Acre Farm. The acreage suggested is a rough measure for what might be called "a farmlet." It ranges perhaps from three to ten acres. It has to be carried on as a rule near a large market, under a system of intensive cultivation and chiefly with vegetables, fruit, poultry or some combination of these, although it is quite common in some irrigated valleys in the West, especially where fruit is grown. There are cases of a more general type of farming practiced by the owner of the "little farm well tilled," but these are exceptional. This small farm can support a family only where the market is good, the soil fertile, either naturally or under commercial fertilization, and where the family can do the work without hiring extra labor, ex- 


\section{THE FARMER AND THE NEW DAY}

cept possibly for harvesting. In some cases such a place will be occupied by a family which has partial support from other sources, but desires the country life and work for the sake of health or the better education of children, or just for sheer love of the country itself. There is evidence that the number of these little farms is increasing quite rapidly, particularly near the Atlantic seaboard, north and south. Negro farmers in the south and recent negro immigrants to the north seem to seek these small places rather than continue as wage workers. There is every reason to suppose that with the growth of cities and the resultant better markets and the increase in the price of land, very small farms will become a characteristic feature of American agriculture and will have a considerable influence upon certain types of production.

The Workingman's Homestead. This is primarily not a matter of growing food but a chance to get a house. It is an expression of the desire to leave the crowded tenement and to find a separate house with land enough about it to insure good health, sunshine, and privacy. These little plots of one-tenth or perhaps not over one-twenticth of an acre, worked night and morning by the head of the house with more or less help from other members of the family, will grow a considerable quantity of fresh vegetables and fruits, accomplish quite a substantial saving in money, induce a larger consumption of fresh fruit and vegetables of much better quality than has heretofore been the case. This is by no means all the good that may come. In such a home, family life can be better developed than in the tenement. Children are educated by contact with growing things and get a little at least of the same advantage that comes to the farm boy who learns early 
in life to deal with things practical. Not the least of its advantages is that it creates respect for the farmer. This movement had gained quite a headway in Europe prior to the war. It had shown itself chiefly in what are called the "garden cities" of England and to some extent in this councry. No workingmen in the world are housed so well or, on the whole, live so well as those grouped in separate houses, not over eight families to an acre. Do farmers realize the difference between a housing plan that takes care of perhaps forty people on an acre and a housing plan, or lack of plan, that purports to care for 4,000 people on an acre? This arithmetic preaches its own sermon on behalf of humanity. In some cases more ambitious workmen will undertake larger areas - perhaps the one-acre or two-acre plot, in which case more of the work will be done by the women and children in the family, or by the man himself if employed chiefly in the winter, with light summer work. More and more frequently the workingman who can get enough land will seek to retire from wage earning before he reaches the dead line, because when his children are grown it may be possible for him and his wife to earn very comfortably the larger share of their living from this small plot. Before the war Belgium was perhaps the best instance of the development, on a large scale, of the workingman's homestead insofar as numbers are concerned. Thousands upon thousands of Belgian workingmen living on "farms" of an acre or one-half an acre went many miles every day to and from their work. This was only possible where rapid transit at very low fares was common. In Belgium the government-owned railways provided these requirements. It is clear also that this movement involves the coöperation of large employers of labor, not 


\section{THE FARMER AND THE NEW DAY}

only in the location of factories but by helping to provide plans, credit, supervision, and education. The provision of workingmen's homesteads promises to be one of the great social movements of the New Day.

The Factory Garden. This is, in America, purely a war development. The manufacturer sets apart or rents a considerable area, perhaps ten to forty acres, organizes it as a unit of management, and allots parcels to individual employees to till. This plan requires expert supervision, as well as the preparation of the ground, the purchase and application of fertilizers, and probably the purchase of seed, by the employer. This scheme has proved substantially helpful in increasing the food supply of the workingman, but it is likely to be rather temporary as a large movement. It may, however, play quite a part after the war for those workingmen who are for any reason barred from garden cities and yet who wish to work parcels of ground.

Use of V acant Land in Cilies. Tiwenty years ago, the mayor of Detroit, Michigan, caused a national smile by advocating the "Pingree potato patch "; but it was a good idea. An enormous amount of absolutely idle land within the confines of every city is worse than useless because it is usually unsightly, it spreads weed seeds, and in a day when thrift is again coming to be a virtue, one rebels at the thought of waste anywhere. Again we may learn from Europe where, to a much greater extent than with us, these idle lands have been put to use. Generally speaking, this plan should be handled by municipalities. It cannot be very successful or widespread without invoking a compulsory law to bring such land into use under terms that are fair to the owner. The use of these plots needs organization and superintendence because most of the workers are not ex- 
perienced. They especially need protection from vandalism. To thousands of dwellers of the tenements, the vacant-land garden would be a great boon.

The Community Garden. The English government, during the war, has made a multitude of allotments of land to workingmen by which they can grow a portion of their own food. It is understood that food production in England has increased fourfold during the past two or three years, and that this increase is largely due to the small allotments to thousands of people who had never before grown any part of their food supply. Allotments may be handled by cities as just suggested, utilizing the vacant land. Another development may be the provision by the community, small or large, for its own fruits and vegetables. This may be either by arrangement with individual growers or by municipal management of the enterprise.

Several successful community gardens have been conducted in Massachusetts during the past season. The city of Worcester furnished a tract of land, plowed and fertilized it, and divided it into plots of one-eighth of an acre. Any one might secure one of these, pay for the plowing and the fertilizer and plant what he wished. A garden supervisor was provided by the county farm bureau. The gardens have been counted as very successful. The town of Newton adopted a somewhat different method. The town furnished the ground, plowed and fertilized it and supplied seed potatoes for planting it. Any citizen of the town was allowed to work upon this tract and according to the amount of work each had done the crop was divided at the end of the season, after the expenses of plowing and fertilizer were deducted. This method likewise has been very satisfactory. 


\section{THE FARMER AND THE NEW DAY}

The Home Garden. The home garden in the village or in the suburban town has long been characteristic of America. It does not need much attention from outsiders. It is an individual matter. To many people it constitutes one of the great attractions of the life in the smaller group. While it is to be encouraged, it can hardly be organized.

The Farmer's Garden. There are thousands of farmers who regard a garden as a nuisance. They won't "fuss" with it. They have no time for it. They have "bigger things to do." So the garden is neglected and the result is an astonishing lack of variety on the farmer's table, where one would naturally expect the greatest variety. The luxury of fresh fruits and vegetables is missed by those who could have them most easily. In some whole regions of our country, canned fruits and vegetables are bought on store credit and used in lieu of home grown products. One of the big educational campaigns of recent years has been conducted by the Department of Agriculture to try to meet this astonishing situation. Some farmers have proposed that in a community of farmers whose chief interest is in stock growing or general farming, there might be either a community garden or an arrangement with certain individuals for the growing in the community itself of fresh fruits and vegetables, the other farmers furnishing the market. In other words, it would be perfectly feasible for an organized community either to arrange with one of its number to grow "garden sauce "for the neighborhood, or to hire a specialist to manage the community garden.

Boy's' and Girls' Gardens. The development of boys' and girls' gardens and of boys' and girls' agricultural and canning clubs has been one of the great educa- 
tional movements of our time. Indeed, its educational value is its chief value, although if we could have an accurate census of the value of the products grown by these hundreds of thousands of American boys and girls both in city and country, they would receive great praise for their practical contribution to our food supply. For the farm boy and girl this movement has awakened new interest in the science of farming, new interest in farm processes, new knowledge of scientific methods and a new love for growing things. It has given the zest of responsibility and possession. It is also astonishing to discover the extent to which city and village boys and girls have participated in this movement. It is estimated, for example, that in the state of Massachusetts this past season not less than 75,000 boys and girls who are not living on farms carried on gardens or even larger enterprises. There is much testimony to the awakening that has come to many a farmer and a farmer's wife through the successes of the boy and girl in trying new methods. It is difficult to overstate the importance to agriculture and country life of the boys' and girls' gardens. It is a selective process. It is foolish to try to keep all farm-bred boys and girls on the farm. It is equally foolish to seek a great migration of city people to the country. But we do want something that will tend to keep the farm-minded boy and girl on the farm and to send the farm-minded city boy and girl to the farm. This the boys' and girls' gardens tend to do. It also will help greatly in making future consumers appreciative of good food, what it costs to grow it, and how it is to be cared for in the home.

The Estate. By this is meant the country home of the man of means whose business is not farming at all. The practice of living in the country for at least half 


\section{THE FARMER AND THE NEW DAY}

the year is rapidly growing. It is a healthy, normal, educative movement. It leads to out-of-door life, to a new understanding of country things, and occasionally helps to educate a community to better farming. However, the growth of estates in this country is likely in the near future to become a real problem. One can see what the possibilities are, if unrestricted, by studying the situation in Great Britain and Ireland up to very recent times. Of course with our abundance of land it will be a long while before the problem of the estate is a national concern. But already in some of the smaller states of the East, land that ought to be producing crops for nearby markets is monopolized for mere pleasure. Of course, if the farming of these estates were really made to pay, the estate would simply become a large scale farm and would be judged on its own merits. It is said that in one county in the East nearly one-half of the land, some of it the very best farming land of the county, has gone into estates that probably will produce one-fourth of what the land would produce if farmed by small farmers growing truck crops for the nearby large markets. We have seen not only in Great Britain and Ireland but in Germany the government itself stepping in to break up the large estates. It is a question that may need our attention in America.

Forestry. Theoretically forestry is a branch of agriculture. When we are fully alive to its importance, we shall treat trees as crops. It will require, however, a very great stretch of the imagination to think of forestry as a branch of farming. The farm wood lot, however, is much more worth while than it seems to most farmers. The time will come when it will be worth while really to conserve our coal, and a not un- 
important item in this conservation program will be the prevalence of wood-burning furnaces in the farm homes, the wood being obtained either from wood lots or the home farm. In the aggregate, this practice would result in an immense saving of coal. Forests are the only crop that can be grown in all rough or mountainous regions. Great areas in both the East and West are useless for anything else, and they are now producing only intermittently and fitfully their full capacity of forest products. It is almost impossible to expect individual owners to change this situation. Possibly trust companies can be encouraged to invest in and develop forest areas on a scientific basis as a means of utilizing funds in their charge. But in general it may be said that the only possible way of establishing and maintaining an adequate forest policy is for the government to do it. Not only the federal government but each state should be moving in this direction as rapidly as possible. It means the best use of the land, better conditions for farming due to the effect on conservation of water, cheaper lumber and so on. Not the least of the possibilities of forestry consists in the fact that a scientific forestry policy carried on by a state over a series of years could be made to yield a substantial income for the support of some permanent interest of the state, such as the public schools. Variations of the effort to grow trees for wood products, are the growing of nut-bearing trees, sugar- and oil-bearing trees, and of ornamental trees and shrubs.

City Forestry. The water supply of a city is a vital concern. As a region becomes exceedingly populous, the difficulty in keeping a supply both adequate and pure increases. There is no doubt that for larger cities at least the question of adequate forestration of the areas 


\section{SO THE IARMER AND THE NEW DAY}

which supply the reservoirs will become a regular part of municipal policy. The matter of parks and playgrounds is of course of little direct interest to the farmer but of most intense importance to the city; and these, in connection with forests as a part of the park system of a city, have to do intimately with soil and the soil treatment. It is not impossible to conceive of cities ultimately gaining some substantial revenue from their forests. This is already done in some places in Europe. The use of trees and shrubs for decorative purposes in streets and parks and in fact the whole question of what is called city forestry, including planting, care, protection from the ravages of insects, and disease, constitutes a large factor in city planning.

The Landscape. When we say landscape, we are likely to think of parks or estates of the wealthy, but the farmer has a landscape with him every day. Perhaps he too seldom uses his opportunities to make his surroundings beautiful at small expense. The beautification of country highways, the establishment of village parks and playgrounds, the landscape adornment of public buildings, schools, churches and Grange halls is too much neglected. But there is the landscape as nature has it. The farmer has access to beautiful views. Does he not sometimes need education in landscape appreciation?

Soil Specialties. There are other uses of soils than the growing of food, feeds and fibers. Floriculture is a large industry. The systematic production of the medicinal plants is increasing. Specialties, such as mushrooms, rhubarb, etc., sometimes make quite profitable returns. Seed farms and nurseries are common. These specialties will increase in number and in the aggregate they will eventually comprise quite a sub- 
stantial business. More than that, they represent a very intelligent use of the soil and a highly skilled utilization of plants.

The Soil and Social Amelioration. It has recently been stated in France that the victims of shell shock recover much more rapidly if they can be put to work in the fields. Better than medicine, better than nursing, better than the hospital is the soil in the open country. Now this statement is only a new illustration of the fact that both physicians and social experts discovered some time ago and to an increasing extent are putting into operation. It is common knowledge that schools for delinquents, the old-fashioned "reform" schools, have usually been placed in the country. The most enlightened prison policies now provide for farms in connection with the prisons and the habitual use of prisoners in producing their own food. Not long ago, one of the most prominent experts connected with the treatment of the feeble-minded asserted that in the future these institutions must consist of colonies so located that the inmates could not only have open air but farm work. It has been found that even the insane can be used to a very large extent in many farm operations. The outof-door work tends to health; steady employment makes for mental poise and sanity. In all these institutions there is some considerable saving of expense to the state. If properly managed, these farms could be also demonstrations in good farming. It should be more generally understood that the increase in delinquents of various sorts, physical and mental and moral, is becoming a serious menace to our civilization, both in country and in city. If, therefore, the use of the soil as a means of amelioration and possibly of curing is practicable, it has very far-reaching consequences. 
We shall also need to provide easy facilities by which those who are partially disabled, either pinsically or nervously, can be placed upon the land. It will not do to arrange for these people under the expectation that invalids can do fam work. But men who need to be out of doors, and can do fairly active work or men only partly disabled can farm small pieces of land in many cases to advantage. This is destined to be a part of a national policy for taling care of the considerable current of men and women who would seek the country if they knew the way.

Game Farming. Just as there are soil specialties, so there are animal specialties, growing of pets, of furbearing animals, of game. In general, the state itseli or large land holding concerns can carry on these types of farming to best advantage. In some portions of the country, naturally wooded, and in connection with the forestry policy, game farming can be made a considerable factor both in the production of meat and in the increase in value of animal products. A variation of game farming is fish farming, that is, the use of fresh lales, ponds and streams for the production of fish. We are just beginning the development of this field.

The Soil as a Machine. The average American thinks of the soil merely as a slorchouse of plant food. But in all older sectled regions farmers discover that it is desirable to make a highly intensive use of the soil, not so much a reservoir of fertility as a container of fertility. Commercial fertilizers are added to the soil and furnish the major part of the plant food. Cilass farming is dependent upon this use of the soil; as are also crops that are grown out of their normal scason. When an effort is made to get unusual yields of special quality, the same principle is brought into operation. 
It is a principle that has the utmost significance in all countries where population presses upon available farming areas. This is not "farming" in the ordinary sense of the word; but again it is a highly intelligent and skilled use of the soil for growing things that man wants. We have here a powerful social appeal to people to tie themselves up with a bit of the land for the sake of health and sanity and good influences.

All this field of farming that is not farming is therefore sure to broaden. It ought to have the sympathetic understanding of the farmers. It is really big with importance for humanity. These things also mean a gradual change of attitude on the part of consumers. When they have their own gardens, they will come to know that cabbages come from the land instead of from the grocery. They will know something of the toil and sweat and disappointments of the producer and of the real cosis of production. They will themselves develop more discriminating tastes and will increasingly call for higher quality; and of course the demand for quality in the long run spurs the farmer to his best effort and best profit. On the whole, it will make for a freer consumption, especially of fruits, vegetables and pouliry products, which can usually be grown in areas near the market, and a reduction of costs and wastes of transportation, storage and distribution.

This twilight zone also has a tremendous significance in an educational way. It is working itself gradually into the system of public education, and calls for trained administrators. It promises to send students in largely increasing numbers to the agricultural schools and colleges. It even means something in the way of quantity production and ought thereby to assist in solving the problem of food supply. 


\section{CHAPTER VI}

\section{WANTED: A RURAL POLICY}

The title of this chapter seems to convey the idea that a rural policy does not exist in America to-day. Such a statement may be denied, especially among government officials and scientists who for years have been very hard at work on definite plans for the improvement of agriculture. As in most discussions, conclusions depend upon definitions. In one meaning of the word, we have and always have had an agricultural policy; in another, and we believe in a truer and much more important sense, we do not have such a policy.

We may think of a policy as the sum of things actually done and under way. These activities and plans show themselves in legislative enactments, in the work of public agencies and in the associated efforts of farmers. The reasons for them may be found in speeches made in Congress, in addresses at agricultural conventions of various sorts, in reports of committees and commissions of many kinds, in platforms of political parties, in the farm press, in the formal pronouncements of great farmers' organizations. A democratic people think and plan in obedience to certain ideas that are traditionally accepted or that arise out of new conditions. For there is always a philosophy, even if unexpressed or incomplete, back of human activities. In this sense we have of course a rural policy. It is composed of many items. It is not in print. If you ask for it, no one can give it to you; but it exists. 
But a true policy must have a certain completeness about it. It can be rather definitely expressed and understood. It must be widely and generally accepted; it directs efforts and governs activities. Government, farmers' associations and individuals will join in a common effort for one large end, intelligently, earnestly, coöperatively. This sort of rural policy we do not have in America to-day. This chapter is written as a plea that we take steps as soon as possible to secure it. Indeed, this whole book grows out of the earnest conviction that perhaps the outstanding defect of our American agriculture is the lack of a rural policy. We must have such a policy if the American farmer is to adjust himself to the demands of the New Day.

Our policy in the past has consisted of three main endeavors:

I. To increase agricultural production, chiefly by opening for agricultural use as much land as possible and settling it as rapidly as possible; but also by education, exhortation, expert advice and government subsidies in special instances;

2. To encourage one-family farms owned by those who till them;

3. To increase as much as possible our exports of agricultural products, both raw and manufactured.

These purposes may not have been always expressed clearly, or definitely held by the leaders, but the trend of our legislation for nearly a century was in these directions. There are those who believe that this policy 


\section{TIIE FARMER AND THE NEW DAY}

was overdone. P'robably in the main it was the one best adapted to the times. The American farmer conquered a continent for civilization under this policy.

The farmers' interests for the first two-thirds of the nineteenth century were largely educational and social. lit was an era of the development of agricultural fairs and farmers' clubs. 'There was not much discussion of economic difficulties. but the period of the Civil War saw the beginning of discussions about bad business conditions under which the farmers had to work, and the last third of the century saw the rise of the great farmers' organizations. These various voluntary associations of farmers have grown to perfectly enormous proportions. They may be grouped as follows:

Associations to improve production - live stock, dairy, horticultural societies.

Associations to improve marketing and exchange credit unions, supply associations, coüperative selling societies, mutual companies.

Associations to improve country life - the church, women's clubs, improvement societies.

Associations of a general or inclusive character the Grange, the Farmers' Union, etc.

We also have an elaborate system of agencies supported at public expense - administrative, such as national and state department of agriculture, boards of education and of health; educational, such as special agricultural schools, country farm bureaus, agricultural colleges and experiment stations.

There have arisen many urban agencies, such as manufacturing concerns, banks and boards of trade, which have a genuine concern and active interest in rural affairs. 


\section{POLICIES BUT NO POLICY}

What, therefore, we have really done is to build much machinery designed to aid agriculture, most of it tremendously effective; but we have set it up without much regard to unifying the enterprise of rural improvement, or even to securing coöperation in the machinery itself. We have, for example, the parts of a perfectly enormous plan for agricultural education; there is nothing comparable to it elsewhere in the world. The statement frequently appears in print and is made in fervid public addresses that the government has done something for every interest but agriculture. It is not true. Probably there is no country in the world which has developed such a wide variety of voluntary collective or associated efforts on behalf of agriculture and country life as has our own. Their names are legion. But in large measure each agency "does that which is right in its orvn eyes." There is no agreement as to what the rural problem really is or how to solve it. There is no statement to be found anywhere clearly indicating the real task of any one agency nor its relation to the service of other agencies. There is no clean-cut coöperation of available forces for definite purposes or ends. Even in so well developed a part of our machinery as the established activities of agricultural education, we may safely assert that we have no well rounded policy.

Perhaps the most serious feature of the situation is the fact that so often we mistake the mill for the grist. Most of the questions that arise in the extension service of nation and state concern themselves with machinery of operation rather than with true objectives. If you ask the average agricultural college official for his 
policy in a specific field of rural endeavor, he will almost always gire you a program or project - and at that a program of methods to be used rather than a list of goals to be achieved. If one were to keep an accurate time slip of subject matter of discussion in the typical state Grange meeting, he would probably find that not less than three-fourths of the time had been spent in dealing with the machinery of the organization against one-fourth in considering the problems which the organization is intended to help the farmer solve. These tendencies are in a measure simply the danger common to all associated effort, what the sociologist calls " institutionalism." School and church and government and all collective agencies are tempted to magnify the institution itself, rather than its real purpose. One of the most powerful arguments for the development of a definite policy is that it will tend to substitute aims or purposes for methods, to emphasize ends rather than means, the grist rather than the mill. IVe might well endorse I.loyd George when he said, "I deal not with plans, not with details, and above all not with programs. I deal with objectives." We must define our agricultural objective.

In the best, truest and most important sense we do not now have an American rural policy; we should have one and we should have it soon.

\section{A FEW QUERIES}

It is quite possible that some influential leaders of our various agricultural enterprises still remain unconvinced of the need of a policy for rural affairs, or assert that we have such a policy. $\quad \therefore$ fer questions may perhaps serve to bring out more clearly the fact that we are trying to establish. 
Is it not merely good sense to have before us a clear statement of just what is involved in making American agriculture all it ought to be? Yet we have never had such a statement carefully formulated and placed before our people, by any group of men and women fully representing all the various aspects of the rural question. The nearest approach was the report of the Roosevelt Country Life Commission, made nearly a decade ago, - which Congress refused to publish for distribution!

Has not the war made clear to all thoughtful people, what ought to be self-evident, that the practical problems of agriculture not only cannot be divorced from the general question of food supply, but that the latter is the real point of departure in determining what agriculture ought to do and can do? But this adjustment of production to consumption of food has never been attempted either by the agencies of gorernment or by the farmers' organizations. The former have for years been "speeding up " production, with tardy attention to distribution, while the latter have been chiefly concerned with the fact that the farmer is disadvantaged in his buying and selling. Even the war has not yet unified the attack on the food problem as a whole; emergency enactments by Congress seem to give duplicate powers to both the Food Administration and the Department of Agriculture, and in actual administration there has never been a definite coördination of either purposes or activities.

May we not learn from older countries? There are those of course who persistently hold that we cannot learn anything worth while from the development of European agriculture. To-day, doubtless the mere suggestion that Germany, for illustration, could teach 


\section{THE FARMER AND THE NEW DAY}

us much would be received with great disapproval in some quarters. No one who has come into eren superficial contact with the organized activities of agriculture in almost any enlightened Luropean country can but feel licenly the loss to American agriculture through our failure to profit by Luropean experience. Individuals have written about conditions, the government has published a few documents on the subject, and five years ago the American Commission made its tour of Lurope for the purpose of studying chiefly agricultural credit, and our present farm land bank system is due in great measure to the Commission. We have had a few reports from our consuls concerning agriculture. Lxperts have scoured the world in a search for new varieties of plants. But we have quite neglected to provide oficial expert means for learning, for example, about business comperation in agriculture, which is one of our most serious problens and in which the Iuropeans are clarly our masters. There is every argument for maintaining a group of qualified representatives of the Department of Agriculture constantly in service in foreim lande, studying all phases of the rural problem, and bringing back to us such lessons as are applicable here.

Why should not we, in common with other nations, consider agriculture after the war? England has its Selborne report. Books are being written in France. The Italian War Cabinet has issued a statement on the subject. It is clear, is it not, that the agricultural policy of Europe will profoundly affect our own agriculture? Arailable material from England seems to indicate a purpose "to malie the Empire independent of other countries in respect to food supplies." Perhaps this aim is the proper one. But what of its effect 
upon the American farmer? We exported to England alone in 1913 food products to the value of more than $\$ 512,000,000$. Does England expect to sell us goods after the war? If so, what shall we pay her in? What shall we do with those \$5 I2,000,000 worth of food we used to send her?

Well-founded rumor states that definite and large plans have already been formulated by American marufacturers, bankers, and merchants, for a vast enlargement of our trade with South America. With what is South America to pay us for the goods we send her? Probably to a very considerable extent in wheat and meat. Now these are among the great sub-industries of our American agriculture. What effect will the new trade with our southern neighbors have then upon American agriculture? Our imports from South America increased from $\$ 200,000,000$ in $\mathrm{I}_{9} \mathrm{I}_{4} \mathrm{r}$ to $\$ 550,000,000$ in 1917 . To what extent was this increase made up of food products that can be grown in this colmtry? Is there any one studying these currents or tendencies, any one in touch with the South American statesmen who are making their policies? Has the war taught us nothing about economic preparedness? Is agriculture still to be the last thing considered in the business discussions of the world? Why should not oficial representatives of our government, presumably officials of the United States Department of Agriculture, be sent to South America as well as into our own business circles, to discover tendencies, to discuss principles and to help formulate programs with respect to the effect of all these new plans upon American agriculture?

The whole world is talking "reconstruction." Labor has assumed that its interests are paramount in 


\section{2

the New Day. Why neglect the largest group of laborers, the farmers? Why are we not studying the problems that the war will bring to our farming population? A recent book deals with American problems of reconstruction. Yet it not only has no chapter that considers agriculture aside from one on distribution, but the words "agriculture " or "farm " are not found in the index. Is the subject unimportant or is there no one capable of dealing with it?

One of the great wastes in our food supply is the constant re-shipment of products. Thousands of small cities bring in food products from rather distant distributing centers of precisely the same type as those grown in the surrounding country which in turn are sent to a distant market. Shall we never have an adequate study of this waste and how it may possibly be remedied?

Is there any state in the Union that has inventoried its agricultural resources or developed a consistent agricultural program on which all agencies are at work for a common end?

For nearly twenty years, the market milk problem in the great eastern cities has been one of increasing seriousness and difficulty. In New England, for example, dairy farmers, pestered with attempts at legislation and control, have been going out of business. Valuable studies have been mate, hut the difficulty has not as yet been "tackled" in the only way in which it can be solved - that is, as a $\cdots / h n l e$. Only when the entire problem is viewed as a unit, and producers, distributors and consumers, together with investigators, teachers and recrulatory officials, come together in a definite consistent effort, each to do his part in working out a sound dairy policy for New England 
- only then will the dairy farmers get permanent relief.

\section{LAND FOR RETURNING SOLDIERS}

The most recent and most serious illustration of our lack of a rural policy relates to providing lands for returning soldiers. Last summer the Secretary of the Interior addressed an earnest letter to the President, urging a plan of land development by which we should know the possibilities of reclaiming arid, wet and cutover lands, and a scheme of enabling the returning soldier to take a parcel of land, pay for it over a long term and make it his home. The amount of the land that could thus be brought into cultivation, it is estimated, would be all the way from one hundred million acres to perhaps three or four times that amount. Provision was to be made by which these farmers would be assisted by technical experts in building up their farms.

One cannot question the sincerity of the Secretary nor the desirability of insuring satisfactory employment for returning soldiers. But the plan is open to many and serious objections. It is doubtful if any large number of returning soldiers, not already tied up with the soil, will want to go to the land permanently. We now have about five hundred million acres of improved land in this country. The addition of $60 \%$ or even of $20 \%$ to this area within a few years would be a most serious menace to the present farmers who already suffer from competition. Of course if the food needs of the world require the use of this extra land, well and good. The project as announced by the Secretary is primarily an engineering program. Apparently no consideration had been given to what crops could be grown on this land, the need of those crops, 


\section{THE FARMER AND THE NEW DAY}

how to market them, or to similar problems. There is no provision for furnishing farmers with capital which they need for their requirements.

The main objection to this plan does not consist at all in details such as these, but in the fundamental difficulicy that these plans, good or bad, have not been developed as a part of an agriculural policy. Thus far, there is no evidence that the Department of Agriculture was consulted. Agricultural experts in the various agricultural colleges have not been consulted, and what is still more important, the great farmers organizations have not been ashed their jurgment as to the effect of this development upon the farmer. It is simply another iliustration of the fact that we do not have a consistent agricultural policy nor at present the machinery for developing it. We still work in groups and not as a whole.

\section{WHO IS TO BLAME?}

This question will not be answered in this book except by saying. "Noboly in particular; all of us in general." These illustrations are not given to point the finger of adverse criticisms at any official, governmental agency or farmers' association, but merely to try to make more real the fact of our lack of an agricultural policy and the pressing need of our being about the business of securing one. Tre have all been shortsighted. liach man and each agrency has been busy in his own field, so busy as to forget the farm as a whole. There has heeri a marrelous development of agricultural inowledge and cnterprie during the last decade or so, and it has been dillicule eren for specialists to "He(e) u!?" in their own fielt. Agriculture is a tremendously big, complex, scattered business. Ef- 
forts at coöperation often fail because of personal or institutional conservatism or jealousies, or natural limitations of either vision or power. Congress and the legislatures frequently quite ignore expert advice. Public funds, great as they have been, have been grossly inadequate for the full measure of the task.

The war has forced the issue. American agriculture must be Ioo per cent. efficient. It must be treated as a unit. We must plan for its best interests as a whole. We must have a rural policy.

\section{THE ELEMENTS OF A TRUE POLICY}

What do we mean by a real policy? What are its tests? How may we "ecognize it when we see it? What are the elements of a "policy"?

I. A Body of Principles. A policy, firsê of all, must consist of a body of principles which are fundamental in determining the direction in which efforts are applied. Some of the things that we must definitely determine before we can have a real agricultural policy are such items as the following:

I. Shall we attempt to grow practically all of our own food and other soil grown products, or shall we permit other countries to export to us such products even though we can grow them here? Shall we seek to grow a surplus from our soil to sell abroad? In both cases, the answer will come only in connection with a national policy concerning economic relationships with other nations. Can we grow these products as cheaply as can other countries and if we can, what effect will this low cost of production have upon our farmers? If we desire to sell our manufactured products in foreign markets, shall we take food products in exchange? 


\section{THE FARMER AND THE NEW DAY}

2. In the future, what shall be our definite purpose with respect to the control of the farm land? Are we willing that it should go into the hands of large land holilers and small tenants, or do we desire to perpetuaic the family-size farm owned and worked by the man who lives upon it?

3. Shall we deliberately plan for the zoning of agriculturial production so that each community, county, district, state or region shall grow those products and those alone which it can produce to best advantage in competition with other parts of the country and of the world?

4. Shall our plans of distributing food products be left to the skill of the individual farmer, dealing with the present transporters and handlers of soil-grown products, or shall we encourage on a large scale collective bargaining by farmers, both in buying and selling? Shall we supplement the latter plan with government regulation or management or ownership of the machinery of food distribution?

5. Shall we develop a comprehensive system of protection and insurance, either through government or through coöperative means, with respect to protection not only acrainst insect pests and diseases, but also against fire, flood, drouth, hail, tornado, etc. ?

6. Shall our agricultural educational system attempt to reach effectively every worker on the land! Shall it include the economic and social problems of American farm life? Or shall it be wholly technical?

Theac and similar queries are matters of fundamental aim and purpose. They lie at the root of a real policy.

II. I Program. There must be a definite scheme 
of operations, of goals to be sought. This program should be based upon:

I. Adequate Knowledge. We need to know the facts. We must have command of resources, understand needs and realize advantages, disadvantages, opportunities, possibilities. This knowledge by no means includes solely physical facts regarding soil, climate and the like, but must embrace all economic and social considerations that bear upon the success or failure of agriculture and country life.

2. Definite Purposes. The real aims that are sought in an improved agriculture should be fairly clear. What is the problem we are set to solve? Where do we hope to arrive as a result of our efforts?

3. Effective Methods. A policy must be reasonably clear as to what are believed, by those most competent to judge, to be the very best methods of procedure by which the desired ends may be gained or at least approximated.

III. Machinery. There must be appropriate agencies to carry out the program.

I. Institutions. We assume the fundamental need of group effort. We must rely upon the individual farmer to do his part of the work that needs doing, but we are sure that the great mass of the seven millions of farmers in America can be brought into a common purpose only through adequate institutions or agencies of coöperative effort.

2. Division of Labor. These agencies must divide the field of labor. Each must find its particular task, seek its function. There should be neither overlapping of effort nor overlooking of tasks to be performed. The government should not try to do what the Grange can better do, nor the Grange to do what the church 


\section{THE FARMER AND THE NEW DAY}

can better do, nor the church to do what the farm bureau can better do - each agency to its job.

3. Instilutional Efficiency. Each agency should make itself as effective as possible in its own field. It should have a part in the making of the policy and should support it loyally. But it should make for itself a definite policy and a clear-cut program of operations.

4. Coöperation. There should be the heartiest possible coöperation among the various agencies, each making, in common with the others, a definite effort to help carry out the program.

IV. General Needs. In general there are needed also

I. A Program Maker. This must necessarily be a body representing fully the various agencies and interests. No one agency, not even that of government, can impose a policy on the others.

2. Adjustments. We must recognize the many relationships of any part of the rural problem and the constant adjustment and readjustment that are thus made necessary.

3. Utilization of Lawes of Progress. We should utilize the two great laws of social progress: (A) the law of resident forces under which we learn to depend, "in the long run," upon local and individual groups and agencies for the real work; and (B) the law of external stimulus by which we keep prodding, as it were, the local effort by information, interchange of experience and even urgings and financial aid from sources outside the local groups.

4. Discussion. It is necessary to develop means for constant discussion of the issues involved, of ends and of means, of methods and the checking of results.

5. Leadership. The discovery, training and utili- 
zation of personal leadership, lay and professional, volunteer and paid, is vital.

6. The Rest of the People. We must also recognize that the people of the nation as a whole and the welfare of the entire country must be taken into consideration in an agricultural policy that is best for the farmer and all the farmers, but we want also a policy that, in the long run, will be best for the country, and we should have, if possible, the support of the entire country on behalf of the widest rural policy.

Perhaps this outline will make clearer than anything so far said, how deficient we are in the making of a policy in our rural affairs, as well as the ideal which the greatest efficiency demands that we keep in mind.

\section{SOME OBSERVATIONS}

It may be worth while to mention a few topics that are sure to be discussed when the formulation of a rural policy is seriously undertaken.

What Are the Main Advantages in Naming a Policy? A well developed agricultural policy ought to give greater certainty of aim or purpose. Much of our educational and organizing work is scattered in its aim instead of being bent unrelentingly toward a definite course. A clear policy ought to assist in avoiding duplication of effort. Now we have a multiplicity of agencies, many of them seeking almost the same ends and frequently overlapping their forces. It is also noticeable that in this hodge-podge of effort, due not only to duplication but sometimes to friction and misunderstanding, many important fields of service are neglected. As one of our country life leaders has said, we must have neither "overlapping nor overlooking." The policy ought therefore to conserve mightily the 


\section{Ioo THE FARMER AND THE NEW DAY}

time, the energy and the money of those agencies and individuals that are at work on behalf of agriculture and country life. The adoption of a policy once more ought to insure a comprehusive program. One needs but to glance at even a superficial outline of the farmer's problem to realize how little even our agricultural leaders have worked in terms of thorough-going, wellbalanced development.

Will Men See the Need? Until very recently indeed, there has been almost no discussion in America about an agricultural policy. Indeed responsible officials have asserted very recently that we already have a policy, and evidently believe that there is no need for further discussion of the matter. But the war has raised the issue in a way that will not down. The experience of America's participation in the war to date has brought home to the farmers and indeed to many of the public agricultural agencies the loss of effectiveness that has come because there has been no authoritative program, no generous use of available forces, no spokesmen upon which the government could rely for an expert and representative opinion concerning the best things to do in agriculture. The evidence that men are beginning to realize the need is found in the fact that a number of different groups are now at work quite independently of each other, endeavoring to formulate an agricultural policy.

Unity Impossible. It may be argued that jealousies both personal and institutional will prevent even the formulating of a policy; somebody or some group will want the credit for it all. It is pitiably true that the itch for glory often overmasters the passion for service. It is a severe test of human nature when individuals or organizations jump into the arena, carry off the 
prize and claim the credit although, as a matter of fact, most of the solid, substantial thinking and work has been done by others. But just as some part of our education to do things comes by doing them, so the spirit of coöperation is often engendered simply by cooperating. The war has taught us many lessons in coöperation, not the least of which is that the larger interest of the country and indeed the larger interest of mankind is paramount.

There is no Policy Maker. This is true. No one seems to have any authority to make an agricultural policy. No branch of government, no farmers' organization, no combination of the two, thus far is universally recognized as representative of the most expert knowledge combined with the most representative public opinion. This is precisely one of the problems in an agricultural policy itself. It is, indeed, a part of an agricultural policy to have a group that can make a policy and see it through.

A Policy Impossible. It is often remarked that anybody can make a paper plan, and unfortunately we have been far too content with paper plans. Resolutions numerous as the sands of the sea have been passed for fifty years, relative to farmers' rights and interests. Some of them have been as seed sown in good ground but most of them never come to fruit bearing. One must admit also that in a business so big as agriculture, so widespread, involving so many people, subject to so many fluctuations, it is out of the question to make and enforce the kind of policy, for example that a big manufacturing firm can make and enforce, and we know that even such concerns are obliged to change their policies from time to time. Nevertheless, while we cannot change the course of the Mississippi River, we are able 


\section{I02 THE FARMER AND THE NEW DAY}

to direct the flow of its waters for good rather than for evil. The mere effort to work together for common ends of itself gathers people together for coöperating effort. The history of every well directed farmers' organization or public agency proves the value of a policy. The next step is simply to gain the larger cooperation in place of the partial.

A Policy Undesirable. There will be those who will go so far as to say that a real policy is undesirable, and they will point to autocratic Germany. They claim that a nation cannot have a real policy and actually carry it out unless it exercises autocratic power, a thing not only impossible in Imerica, but even if it were feasible, would be mischievous because it would make automatons of farmers. Here again we must reach the middle ground of common sense and practicability. When we leave the shores of the present chaos of unregarded effort, in agriculture, we do not necessarily seek the haven of enforced militaristic regulation of individual endeavor. We rather seek to enlist the intelligence, the self-interest and the patriotism of the farmers, and the agencies which they have created, in behalf of a well-planned, economic, coöperating, stimulating campaign for improved conditions.

1 Policy Essential. We see no escape from the conclusion that the time is upon us when we must make some sort of policy for agriculture. The need of it was apparent in many minds even before the war, but the New Day makes an imperative demand that society shall plan for its future good and plan carefully and intelligently and immediately. It would be tragic were our American farmers and rural agencies to fail to learn the most obvious lessons of the war.

Whom to Consider. It is exceedingly important in 
making a policy to remember the special interests that are to be taken into account. There is a remarkable tendency on the part of people to plan only with reference to themselves or the special interests with which they are concerned. In making the rural policy, we have to regard at least three elements.

First of all, there is the individual farmer; his interests, his tastes, his needs, his capacities, his prejudices are part of the material with which we deal. A whole chapter in this book will be devoted to an attempt to show that the individual farmer, however, can most effectively be reached if he is approached as a member of a small group - the local rural community.

Then we have the associations of farmers. Their names are legion. These more nearly represent the farmers than do any governmental agencies, because they are made up of farmers, who speak the farmer's language and enforce the farmer's opinion. It is true that the measures they advocate may not always be wise or scientifically sound, but these associations constitute the big factor in agriculture. If there should arise in America any tendency on the part of publicly supported agencies to ignore the power of volunteer association in agriculture (or to overlook) its ultimate worth in keeping the farmers a body of sturdy, independent men and women, it would spell the decline of democracy.

In the third place, we must remember that the government is constantly enlarging its functions and widening the range of its services. Governmental machinery, therefore, becomes a constantly increasing power; so if the farmers' associations ignore the departments of agriculture, national and state, the colleges and experiment stations, the farm bureaus and the schools, they cut off their right hands. Democracy needs ex- 


\section{IO4 THE FARMER AND THE NEW DAY}

perts; to cast aside the skill, the knowledge, the foresight, the judgment of these specialists, fallible and imperfect as they are, would undermine immediately any attempt to operate a permanent agricultural policy. No one of these interests can make or execute a policy by itself. Neither the individual farmer nor the voluntary associations of farmers, nor the government itself is sufficient for the task. All must be taken into account and must be brought together.

An Agricultural Program and the Food Supply. So far as we know, the first effort in America to outline in conference a program for agricultural activities that took as its starting point the food needs of the time, was made in St. Louis in April, I9 I7, under the leadership of Secretary Houston of the Department of Agriculture. (The major part of the St. Louis statement appears in the back of this book. See Appendix III.) This statement is not an ideal outline of a rural program. It was not the result of a conference of all the agricultural agencies, but only of a part of them. It was made hastily. It was frankly a war measure. It did not compass the entire agricultural problem. But it was nevertheless extremely significant, so significant that it will probably go down into history as the turning point in American agriculture. Before it was adopted, we had no comprehensive, consistent agricultural program worked out by a responsible group of men and fitted into the food needs of the people. The St. Louis statement was in itself a food supply program; it was made in conference; it called for central national committees of both farmers and experts; it advocated complete machinery, national, state and local, for carrying out the program. It is interesting to note that the machinery urged was in the form of agri- 
cultural councils - national, state and community, a thing new to our American agriculture.

Breadth and Bigness. Last of all, let us observe that a rural policy must be just as big and as broad and as far reaching as is the American rural problem.

\section{THE GREAT AMERICAN FARM}

Let us come back to our starting point. We must think of all the farms of American farmers as really one big farm, and we must endeavor to do just what the good farmer would do in answer to the question, "How can that farm be made more efficient and how can the people who do the farming be made more prosperous and happy?" Once we get firmly in our minds this very simple prescription for the improvement of American agriculture and country life, we will plan for the development of American farming and the welfare of the American farmer and his family, just as if we were dealing with one big farm and one big family.

\section{MAKING THE POLICY WORK}

There are two great forces on which we must rely for the development of an agricultural policy and the working out of a rural program. They are education and organization.

Education, used in the broadest sense, must include technical knowledge, ample information as to conditions, grasp of principles and enlightenment as to ends and means, as well as appreciation of broad relationships and of obligations as well as rights.

Organization is the coöperation of all the factors, all the institutions, all the individuals and groups that can assist in the forward movement of agriculture and country life. 


\section{CHAPTER VII}

\section{THE EDUCATION OF THE RURAL PEOPLE}

Education is the life-blood of democracy; ignorance the ally of autocracy and of all predatory forces. If the people are to be trusted, they must be trustworthy. The recent declaration of the British Labor Party states that "the most important of all the measures of social reconstruction must be a genuine nationalization of education which shall get rid of all class distinctions and privileges and bring effectively within the reach not only of every boy and girl, but also of every adult citizen, all the training, physical, mental and moral, literary, technical and artistic, of which he is capable."

The instincts of the American farmer in this respect are sound to the core. A prominent leader of a great farmers' organization was recently asked what were the big problems of American farming. He put first the securing of an adequate system of education. Repeatedly have the formal utterances of important farm groups and their leaders given the same rank to education; they recognize the hopelessness of agricultural improvement apart from a widespread, effective educational scheme. The Grange for fifty years has maintained a lecturer's hour as a regular part of the proceedings at every subordinate (irange meeting. It has always upheld the public schools and the agricultural colleges. It has reports of committees on education at 106 
every state and national meeting. It has assisted in developing parents' and teachers' associations. Perhaps the characteristic feature of the Grange as compared with other farm organizations is its insistence upon education. This attitude of the Grange is but an expression of the mind of the better farmers. When the farmers began to settle the West, they carried the school with them; it was a part of their community luggage, indispensable at a time when luggage was a burden. The farmers' own efforts to improve agriculture are based on an abundant faith in education as a prerequisite to all else - upon the belief that if the farmer is educated all other things will follow; but that if he is ignorant, there is little chance for real gains. The farmer knows that the mind is somewhat like one of his fields - cultivation is half the crop.

\section{DEFECTS IN RURAL SCHOOLS}

Nevertheless, one of the most serious difficulties in adjusting the farmer to the New Day is the fact that rural schools are not keeping step with the needs of the time. Unfortunately, in spite of their belief in education, the farmers themselves block the progress of education all too often, through an unwillingness to make changes in antiquated equipment and systems, or through sheer parsimony in financial support. There is often lack of local enthusiasm and ideals. Farmers in many regions are all too content with what they have. Sometimes they are simply stubborn, desirous of doing as they please and resenting outside advice or suggestions. As one of our agricultural leaders has said, democracy and education oftentimes have been interpreted as being the right for any community to have as poor schools as they choose to have. There are farm- 
ers who do not realize that the school of yesterday will not answer as the school of to-morrow.

Not all of the difficulties in developing the rural schools are to be laid at the door of the farmer. State aid is often inadequate. Supervision is not seldom poor. School officials are often obliged to pay too much attention to politics; sometimes they endeavor to transplant bodily the city school system to the country. There is no national program of rural education based upon the fundamental relationships between education and rural democracy. We can progress rapidly only when we have a program that is vital and practicable, one that appeals to the farmers and has their support. We need the vision to organize a great national movement in behalf of the rural schools of America.

\section{SOME ITEMS OF RURAL SCHOOL IMPROVEMENT}

The rural schools should be as good as the city schools. They may not teach the same subjects or in the same way, but the country boy and girl in all justice should have opportunities equal to any offered anywhere. Some farmers do not realize how backward many rural schools are. And perhaps some educators do not realize what good results actually come from the better class of country schools. But we can hardly say with truth that the education given in rural schools to-day is as good as that given in the cities.

We must insure better teaching - far, far better teaching. There is an astonishing amount of good teaching in the country schools, but it is really a marvel that it is as good as it is. The majority of rural teachers are not properly trained. They get very small pay, they stay in the school a very short time. Reforms at these points are fundamental - higher salaries for bet- 
ter trained teachers, longer periods of employment and the securing of teachers who will become community leaders.

The effort to establish the consolidated or centralized school has been going on quite strongly for fifteen or twenty years. The plan itself is making rather slow headway. But wherever it has been tried, it has proved a success. It is amazing that in many parts of our country the farmers have been so slow to meet the educators half way on this subject. Of course, there are difficulties, bad roads are among them; because there must be transportation of pupils if there is to be a consolidated school. The consolidated school is more costly in money than the old district school system, but it is far more efficient as an educational mill. It permits better supervision and gives a chance for the employment of better trained teachers at a better wage. It allows them to specialize in certain subjects or with certain grades of students. It secures a better course of study and it more easily provides "teacherages" or dwellings for the teachers, and consequently makes the school faculty a part of the community leadership. It makes possible a high school in many communities that otherwise would be deprived of it. Agriculture has been prescribed in some states as a required subject in the grades of the rural schools. It is a useless law and an unfortunate requirement unless it can be taught by teachers trained in agriculture. The reason for introducing agriculture and country life subjects into the average country school is not primarily to educate for agriculture, but to educate by means of agriculture. There comes a time, it is true, when a boy must make his choice and if he is to be a farmer, he ought to be definitely and thoroughly educated for agriculture. 


\section{IIO THE FARMER AND THE NEW DAY}

But it would be absolutely mischievous to plan the rural school system on such a basis as to direct all the boys and girls back to the farm and to make it difficult or impossible for them to compete with the city boy or girl in other professions and occupations of life. One reason for introducing agriculture into the grades of the country schools is the educational value of using the surroundings of the pupil as a means of education. Natural scenery, the business of the community, problems of the adults, are the real materials of education. The pupil is to be encouraged to ask questions about these things, to get the meaning of them, to see if he himself has any relation to such questions. It is frequently asserted that the course of study and the text books used in the country schools are of such a character that the pupils are becoming interested in the problems of the city rather than the problems of the country; many teachers in the country schools are themselves looking toward the city. This is a sound criticism, but the remedy may be carried too far. An assumption that the schooling of the country boy and girl should merely train for life in the country is disastrous. If one were required to choose between a country school that gave a first class general education, but with no agriculture, and a technical or vocational course without the facilities of a general education, there would be no hesitation in the decision. Far more important than a specialized training for arriculture, is a real, thorough, vital education. Fortunately we need not be obliged to make such a choice, because a really good system of rural education will include an ample amount of training for the business of agriculture, and a good training for farming will not nerlect to teach the pupils that man does not live by bread alone. 
It is sometimes said that the high school is the "people's college" and there is a rapidly growing tendency in our city high schools to offer what is to-day regarded as normally the first two years of college work. In some of our smaller cities and larger villages, a very large proportion of the boys and particularly of the girls go on through the high school. It is here, in the high school advantages, that the discrepancy between our city school opportunities and our country school opportunities shows at its worst. The democratic movement everywhere to-day looks toward keeping the boy and the girl in school to the age of 16 rather than of 14 , and there are those who advocate compulsory part time schooling at least up to the age of $\mathrm{I} S$. The people themselves are beginning to be convinced that it is worth while for each boy and girl to get all the formal organized teaching that is possible as preparation for occupation. But that is not all of it. There is a growing belief among the masses of the people that one of the great advantages of keeping the boys and girls in school for a longer period is that they may be better fitted for the responsibilities of democracy. Of course, this calls for vast changes in our high school work. It means that not merely vocational training is to be given boys and girls of the ages of I4 to I $S$, but also preparation to help meet the common problems of citizenship. Now if the farmers cannot have the advantages that are rapidly coming to the sons and daughters of the so-called working people in the city, agriculture is destined to drop behind slowly but surely. It is an encouraging fact that in many of the larger agricultural sections oî our country an unusual proportion of the farm boys and girls go on to high school and even to college. But over against that is the sad fact 
that among four-fifths of our farming people, the majority of the boys and girls do not even finish the eighth grade.

The New Day demands radical thinking and decisive action on the part of the farmers as well as on the part of educators, concerning the rural school system. Farmers doubtless will object to raising the school age to 16 , because they feel that they need the work of the children on the farm. But there are devices that will help to modify the immediate economic disadvantages of lengthened schooling. Among these devices are the part-time school and continuation schools. The extension of the present plan of winter short courses in agriculture offered by our agricultural schools and colleges ought to meet the situation. If we could have a system by which in practically every community in America there were winter schools of four months for farm boys and girls of the age of I 6 to is (assuming the school age will be raised to 16 ; otherwise from 14 to 18 ) we would at once take a long step in advance. These schools should be agricultural in character but not confined to agriculture. The farmer and his wife in a rural democracy need all the agriculture and home making education that they can get, likewise need all the possible stimulation to closer thinking about the big problems of work and life.

The so-called "practical" farmer, the narrowly vocational education advocate, and the conservative "liberal " educator are together responsible for one of the most serious failures of our rural school system - the neglect of education of our youth in the economic and social questions of the time. The New Day will bring these questions to the very front. Indeed, they are the main questions of the New Day. How shall the hu- 
man race better learn to gain wealth, honestly and efficiently and distribute it fairly and at the same time live together in a more friendly way? Unless these themes are put into the schools, democracy does not get its proper education. Much the same thing may be said in regard to literature, also to art, especially music. How the war has emphasized the value of music as a stimulus to the soldier and how the great movement for community singing that has swept over the country has developed patriotism and common purpose!

It is clear that all these reforms and redirections of our rural school system will cost money, a great deal of money. But we must regard schooling as not a luxury, but a necessity. A good schooling may cost twice as much as a poor schooling, but is worth ten times as much. There is no better scheme of national bargaining than to spend money needed for a good school system. Let us also recognize the fact that these improvements in our rural school system cannot be made if the local farm communities are left to do it alone, or if they alone are obliged to pay the bills. The farmers must give up some of their cherished "rights" in respect to the management of the little local school, not because we want an educational autocracy, but because in this day of scientific efficiency all school systems must yield to the management of wise, trained, broadminded experts in education. We need a larger amount of state aid for local schools. The supervisors of our school systems, both county and state, should be taken out of politics at the first opportunity. These educational positions should no more be political in character than the pastorates of the church. It is one of the most mischievous mistakes of democracy to suppose that a Democratic or Republican county 


\section{I4 THE FARMER AND THE NEW DAY}

superintendent of schools is better than the other, according to one's view of political things. It is one of the left-overs of an antiquated attitude toward the management of public affairs by the people. What the people now demand is educational efficiency and not political attachment. They want educational leaders who are not faddists but real experts, who are given both authority and money to carry out wise plans, unhampered by fear of political interferences. It is probable that our city school systems suffer more than do our rural schools from politics. But the evil is a national one in both city and country and ought to be abolished.

Furthermore, the time has come for federal appropriations for aid to rural education. Some of our educational leaders are strongly opposed to such a policy. They believe that it looks toward undue centralization and autocracy. There is a widespread tradition that education is purely a local matter. But if this was ever true, it is so no longer. In the New Day it is to be seriously, desperately a national matter. Is it anything short of a national scandal that when our great army was mobilized, we found so large a percentage of illiterates? Long since have we discovered that Asiatic cholera is not a concern of San Francisco alone, nor yellow fever of New Orleans alone, nor Spanish influenza of Boston alone, but that any plague spot, no matter how small, is a menace to the entire country. We must cease to think that the failure of any community, large or small, properly to educate its children is a local question. So long as boys and girls have the right to go from one community to another, just so long their education is a national affair. We need a national educational policy with respect to the education of the rural people. We need a strong, well supported national 
Bureau of Education. We need a certain measure of federal support for the local rural school. To deprive this school of its initiative, its local management, of the necessity of local support, would of course be fatal to its best efficiency. The great gain through federal direction and support of the development of a national policy lies in the opportunity to aid and stimulate the small farming community to give its boys and its girls as good an education as can be obtained in the largest city of the union.

\section{A FEW SUGGESTIONS ABOUT AGRICULTURAL}

EDUCATION

During the past fifty years, America has organized a comprehensive system of agricultural education, perhaps in its extent and scope the greatest of any country in the world. There exists an agricultural college in each state, giving both college grade work and short courses for those not desiring to graduate; schools of agriculture designed for boys and girls under i 8 years of age; a rapidly increasing number of agricultural departments of public high schools; the teaching of agriculture as a subject in the high schools alongside of algebra and language, and hundreds of thousands of boys and girls working in the agricultural clubs of the various states. A great army is training for agriculture. But that is only part of the story. Under the Smith-Lever Act of I9 I 2, there was established a national system of extension service which endeavors to reach practically every farmer in the land with the best the agricultural colleges can give. As a result of the act, the farm bureau system is emerging and will soon be found in nearly every agricultural county in the United States. The United States Department of 


\section{II6 THE FARMER AND THE NEW DAY}

Agriculture is by far the greatest piece of government machinery in the world for gathering and distributing information about agricultural subjects. The Department, together with the experiment stations in each state, constitutes a remarkable group of investigational institutions. It is doubtful if farmers realize or appreciate the extent to which public money is now devoted to the three great methods of agricultural education - scientific investigation, the training of leaders and specialists, and the widespread dissemination of information.

But we have not yet solved the problem. A number of matters ought to be met at once if we are to adapt our system of agricultural education to the New Day.

It is highly important that in every state the logical distinction in work between a board, department or commissioner of agriculture, and the colleges and schools of agriculture, should be recognized and acted upon. The principle of division is perfectly clear. The real work of a board or department of agriculture is administrative; that is to say, it enforces laws protecting the farmer or possibly laws regulating his business. It administers the police powers of the state insofar as they are directed toward agriculture. If there is a piece of land development to take place under the authority of the state, its administration should go to the department of agriculture. Whenever the state, through the legislature, attempts to assist the agricultural interests, the administration of those laws belongs to the department of agriculture.

On the other hand, the work of the agricultural colleges and schools is educational. All effort to make thorough-going investigations in any field, whether concerned with the soil or with distribution of products or 
with country life, belongs to the educational institution. The teaching of students of course is the province of the schools. Originally the work of disseminating information belonged to boards of agriculture, but with the rise of the extension service of the colleges and the county farm bureaus, it is clear that their function is also to spread information among all the farmers. This division of labor has been agreed to by representatives of the colleges and the state departments of agriculture. It only remains to carry out the purpose in every state. Misunderstandings have arisen and there has been loss of energy and efficiency on account of this misunderstanding. It no longer should prevail.

There needs to be wide extension of the system of schools of agriculture, intended to be finishing schools, not schools preparatory for college. Doubtless, the boy graduating at such a school of agriculture should be able to secure further education if he wants it. But we cannot have an adequate system of agricultural education unless we have abundant opportunities for training for farming boys below the college age. Indeed, when our system of agriculture is thoroughly developed, by far the larger number of farmers who have studied agriculture in school will be graduates not of agricultural colleges, but of agricultural schools. It is to be hoped that agricultural colleges will send out an increasing number of men and women who will seek their living on the farm. But perhaps the most important development that can now take place in our agricultural education consists in increasing very rapidly the number of agricultural schools.

If we are to develop a system of agricultural education that will meet the demands of the time, we must very soon secure greater unity in the management of 
these various educational agricultural enterprises. A mere listing of these agencies of control suggests the problem. The United States Department of Agriculture is not only in itself a huge educational enterprise but it has oversight of the federal funds spent by the various experiment stations and for teaching in agricultural colleges; it exercises a great deal of authority in the expenditure of federal money devoted to the extension service. The United States Bureau of Education, which will probably become a cabinet department of education, has by law a certain amount of oversight of the federal money used for teaching in agricultural colleges, and of course as a Federal bureau, has a very intimate connection with the entire national system of public education. Our latest piece of educational legislation by Congress is the Smith-Hughes Act which provides for a greatly enlarged plan of secondary education in the industries, agriculture and home making. There is a Federal Board of Vocational Education which has complete charge of the enforcement of this law, supplemented in each state by a similar board. Each agricultural college is managed under a board of trustees, having definite powers granted by the legislature. State boards of education claim an interest in the methods and results of agricultural education simply because they are a part of the system of public support of education. County farm bureaus in at least one state are no longer mere organizations of farmers, but are legally public agencies, supported at public expense. In some states, they are separate schools of agriculture, usually administered under some central authority, either the college of agriculture or the state board of education. Sometimes, however, they are managed locally. Then we have innumerable township or district 
school communities and school boards managing the rural school and sometimes responsible for a rural high school.

Now all these agencies deal with agricultural education to a greater or less extent. One of the great needs in our agricultural work to-day is to secure the definite coöperation of all these authorities, in order to make a complete system of agricultural education. This will have to be done by law and it probably will not be done unless the farmers themselves insist upon it in both state and nation. We are not suggesting merging all these agencies into one, but simply the unification of plan and effort for the sake of efficiency.

$\mathrm{We}$ also need to make a much more extensive and thorough-going plan for the scientific investigation of our agricultural problem. A vast amount of work has been done and is being done to-day. The modern teaching of agriculture has been made possible by the men of science in the experiment stations and the United States Department of Agriculture. This need of enlarged research is particularly evident in the fields of economics and of social life. For years, the farmers have been urging that the problem of distribution is much more important to them than the problems of production; yet only a fraction of the amount of money spent for investigations concerned with the soil and the plant and the animal has been available for making studies concerning markets and other phases of the distribution question. Research must not stop even here. We need some of the best minds of the time at work on the basic problems of human life as they can be worked out in a farm community. What are the fundamental problems of a rural democracy the world over? We must train leaders for this rural democ- 
racy, but they cannot be leaders unless they know the issues at stake. Instinctively, we all know that the great aid given by education to the farmer consists in helping him to work out his human problem - how to take and keep his place in socicty - and yet we are short-sighted enough to call the students of these subjects theorists, and we continue to demand educational results merely in terms of bigger crops.

\section{EDUCATION IN A RURAL DEMOCRACY}

All these suggestions do not after all reach the main issue. They have been made merely to indicate some of the most important steps that should be taken. But we must go down to much more fundamental things. We must gain a new conception of the part education is to play in building up our rural democracy. Education is the very life blood of democracy. Democracy cannot be efficient, indeed, it can hardly exist apart from education. A democratic education, however, is not achieved merely by compulsory attendance at school; Germany did all that. Schools easily become mechanical. Our whole system of rural education now needs vitalizing. Education should become the main concern of our democracy. The statesmanship of education is vastly more important than that of any other one feature of democratic society except that of international relationships, and even the latter is founded on genuine and widespread education. The problems of education are little understood by our law-makers. They are incidental in the thinking of our people. Education is given too narrow a definition, confined to the idea of schooling for the youngsters.

The New Day calls not only for the development of a comprehensive program based upon an adequate na- 
tional policy of rural education and thorough-going cooperation of the different parts of our educational system, but it means education for education. We need a widespread campaign among the people themselves on behalf of the significance and meaning of education in a rural democracy. The farmers are to be trained for their work in its broadest aspects - production, distribution, conservation. They are to catch a vision of their obligations as well as their rights, - all of their relations to the world's food supply, their part in maintaining the fabric of the world. They must rise to the new demands upon the democratic system. They must sense the need of an organization of their forces, both for the sake of self-interest and in order that they may contribute their full share to the solution of our world problems. Education must open up to the farmers the "kingdoms of knowledge." The democratic system must assume that its members want culture, want art, want music, want good literature and that they can not only appreciate it but can live and thrive on it. Education should compass the whole range of human interest for the farmer - work, citizenship, life. Rural education is a matter that goes far beyond the maintenance of a good rural school system or the development of means of agricultural education. These are vital, but they are only parts of the problem. The main task in rural education is to keep the rural democracy forever studying, thinking, discussing, growing. The farmers therefore should back a great movement on behalf of the fullest possible education of our rural people. Our educational statesmen should press for a comprehensive program and take the farmers into their confidence. We have no time to lose. The new world order demands an adequate education of the rural people in every country in the world. 


\section{CHAPTER VIII}

\section{THE ORGANIZATION OF AMERICAN AGRI- CULTURE AND COUNTRY LIFE}

For half a century the leaders of farmers have urged "organization" or "coöperation" as the second of the two essentials to rural progress, and many efforts have been made to organize farmers. The results have not been entirely satisfactory. In earlier days, the aim was to form great farmers' organizations associations dealing with all aspects of agricultural improvement and designed to include the farmers generally, irrespective of the section of the country in which they lived or of the particular kind of agriculture in which they were engaged. The Grange was the earliest and is yet the most typical of these organizations. A secret society, it was frankly patterned after one of the great fraternal orders. It has its rituals, its passwords, its initiations. The Grange movement swept the country, then subsided, and again began a steady but substantial growth. For the past ten or fifteen years, it has more than held its own where at the beginning of the century it had any real foothold. The Farmers' Alliance sprang up and for a time took the place of the Grange, but was finally absorbed by the Knights of Labor and the Populist party. Its successor is the Farmers' Union, patterned in many respects after the Grange but less avowedly pushing its educational and social aims, and frankly ambitious to secure business coöpera- 
tion on a large scale. It has a large membership, chiefly in the South and in the West. The American Society of Equity, organized in the Middle West, has for its main purpose the improvement of economic conditions among farmers. Especial emphasis is laid upon equitable returns to the farmer for his produce.

Another group of societies, started even before the great farmers' organizations, are of special interest. These were associations of stock breeders, fruit growers, dairymen, etc. At the beginning they were intended largely for educational or conference purposes and were only to a slight extent business organizations. Many of them are still of this character, but some of the most powerful are frankly engaged in the effort to improve facilities for collective bargaining and even to influence legislation designed either to encourage or to protect the industry.

Collective bargaining, or, as it has usually been called business coöperation, was one of the great objectives of the earlier farmers' organizations; but this phase of their work has never been a complete success. Indeed, in spite of many individual instances of successful Grange stores, Union warehouses, etc., and in spite of the fact that efforts and discussion prepared the way for collective bargaining, there was a vital defect in the plans. Successful collective bargaining on the part of farmers is dependent chiefly upon the ability of a relatively small group of farmers who live near together and grow the same things, to pool their interests in the buying of supplies and in selling the particular products they grow. The Grange and other great farmers' organizations took into membership farmers who were growing a variety of things and sometimes endeavored to lump all the products together for purposes of sale; 


\section{I24 THE FARMER AND THE NEW DAY}

but the plan never worked well. Moreover, none of these societies actually embraced all the farmers of the community or even the majority of them in most cases. Many Grange members are not producers. Identity of interests is the very foundation of collective bargaining; diversity of interests is fatal to its success. So it has remained for specialized coöperative enterprises such as the California Fruit Growers' Exchange, and more recently a large number of similar efforts, really to set in motion the beginning of a system of coöperative buying and selling among farmers.

\section{A NEW MEANING TO ORGANIZATION}

We are beginning to use the word "organization" in a new sense, and this change of definition is exceedingly important. The idea may perhaps be expressed, first, by saying that "organization" is much broader than an organization. Just as we think of education as far more than school and college, so organization is far more than the coöperation of one thousand people or even a miliion people for some one end. In this book the word "association" is used to describe the various coöperating groups of farmers, and the word "organization" for a different, and we think a larger, idea. But what is this larger idea? We may say that rural organization is the coöperation of all available agencies on behalf of a definite program to improve agriculure and country life and to adjust the interests of farmers to the common good of the nation and of the world. Organization brings to bear upon any problem all the forces that can help solve the problem. Organization is of universal application. An individual can organize his life; so can a nation; indeed the war has brought us face to face with the problem of world organization. 
A farmer can organize his business so that he gets the maximum use of his capital and his labor, his time and his energy; only so does the greatest efficiency result. The housewife may follow similar methods in the home. The large association is well organized or poorly organized, depending upon whether it uses the powers tied up in it by reason of people coöperating, or whether it fails to develop a big plan and to get everybody working to carry out the plan. Schools, colleges, churches, societies, communities, governments, businesses may be well organized or poorly organized, according to the extent to which they succeed in gaining the intelligent coöperation of all the elements available for attaining their ends. It is organization in this newer meaning of the word, supplementing education, that holds the key to the success of the farmer in the New Day.

Let us consider briefly some of the more important applications of the principle of organization to rural affairs.

\section{THE BETTER ORGANIZATION OF EXISTING AGENCIES}

Each institution or associated effort devoted to rural improvement should seek the highest possible efficiency. It needs to take an account of stock and to discover whether the New Day makes new demands upon it. The great established institutions like the school, the farmers' organizations, the church, and government itself, must still be the main reliance of rural effort, now and for all time, but with a new sense of social responsibility that will call for vastly increased effort and possibly almost complete reconstruction.

Each institution therefore needs to seek the most efficient organization for itself. It is a serious matter 


\section{I26 THE FARMER AND THE NEW DAY}

when an important institution settles down to a contentment with its methods and its results. It should be as ambitious as the most ambitious youth, for maximum efficiency and thorough-going organization. It should always be for progress, always anxious to be in the front line trenches. It should never stand still. No matter how glorious its past may have been, it should constantly look forward to new achievement. Not what it has done, but what is next for it to do, is the main concern.

What are the steps by which each one of these various institutions can become better organized? There are perhaps four of these steps which may be mentioned but not elaborated.

I. All institutions tend to concern themselves disproportionately with their methods and working details and to overlook the real ends or purposes for which they are supposed to exist. The most searching selfquestioning on the part of every rural institution is now in order. What is its task or function? How can it most fully help the farmer? What are the large ends for it to seek?

Therefore, each institution should clearly define its own task. This seems a simple enough matter. But very few agencies have tried to do it. They have general notions about what they are to do, but they tend to spread themselves widely and often to disregard the work of other agencies. Lack of aim results in loss of power. The fundamental need is for each institution to ask itself what is the main purpose of its establishment, what is its part in rural improvement, what are the real reasons for its existence.

2. Each institution should develop an adequate policy. What are the fundamental principles upon which 
its efforts should be based? What sort of program is practicable at the present time for the purpose of carrying out these principles? How can this institution best perform its task? What are the methods, devices, plans that will be most effective?

Each institution should have a program composed of a series of definite objectives, together with lists of methods worth trying in order to gain these objectives. This program will vary from time to time, will be different in its application to different parts of the country and even to different communities in the same state or county. It cannot be a hard and fast outline of methods for the local community, but it ought to be suggestive and helpful - devices that have been a success. A so-called program may be merely a piece of writing which anybody with a facile pen can evolve. A real program is hammered out of the thought and experience of the people who are doing the work, and has the advantage of keeping before them something clearcut and definite, something that they can come back to every little while and check up in order to discover whether they are making progress.

3. How can each institution coöperate with other associations and institutions in order to avoid duplication of effort or misunderstanding of purpose? How may this institution participate in the great gettingtogether, the larger coöperation that is evidently essential to rural efficiency?

This is a hard test. Institutions as well as individuals are subject to the human passions of jealousy and envy. One of the most conspicuous examples of this fact is in a community having four or five small struggling churches, when one good strong church would fully suffice. Some of the most unchristian things that 


\section{I2S THE FARMER AND THE NEW DAY}

the angels have to witness occur under these conditions. The only solution is the spirit of community service overcoming the spirit of group pride.

4. Each institution must in some measure train its own leaders. Relying upon schools and colleges to furnish formal instruction, the agency itself needs to determine the sort of men and women it will have in its personnel. Particularly will it seek to develop all latent leadership within its ranks.

\section{THE ORGANIZATION OF AGRICULTURE BY SUB- INDUSTRIES}

Perhaps the most important single step in the organization of American agriculture is the organization of sub-industries or producing groups. By sub-industries is meant wheat growing, cotton growing, apple growing, dairying and so on. This feature of rural organization, so characteristic of agriculture in Europe, has not gone very far in the United States. In the earlier days, the old horticultural societies, live stock associations, etc., were educational in character. Later there grew up quite highly developed associations of breeders of various kinds of pure bred live stock. Their purposes were not always clearly defined but among them that of pushing the sale of their particular breed of stock was prominent. In some parts of the country the dairymen are becoming organized. There are several associations of grain growers and producers of beef cattle that are doing vigorous work. But as a rule the field of effort of these organizations is limited. Perhaps the nearest approach to a complete organization of a sub-industry or a group of sub-industries is found in the work of the California Fruit Growers' Exchange, through which the citrus fruit growers of Cal- 
ifornia have developed an enormous coöperative business. All the other producing groups should get together in similar fashion - the wheat growers, the cotton growers, the corn growers, the butter makers, the market milk producers, and all the rest.

What are the main advantages of organizing subindustries?

r. It enables the growers to standardize the methods of production. There is a premium put upon intensive study and experiment on the part of producers themselves. The principles worked out by scientific investigators and the experience of other producers gradually coalesce in skillful management. Good farmers will always make the best effort, but if each man depends upon himself alone, the chances are that he will never get the best results.

2. Collective bargaining either in buying or in selling is practically impossible except by those who have identical industrial interests, that is, by those who have the same things to sell. They can pack them in the same way and give them a trade mark.

3. Protection of farmers, whether through insurance or protective legislation, is best gained when the combined efforts of those who have similar needs are pooled for the same purpose. Groups of producers of similar products, as a rule, have similar problems.

4. The educational possibilities in this type of organization are exceedingly important. Education is a public function, but unless the work of the schools and colleges is supplemented by the self-education of the farmer, the public money devoted to education is only partly justified. A group of individuals interested in the same business can study all phases of the business much better than any one individual can do it. More- 


\section{THE FARMER AND THE NEW DAY}

over in large, well-organized industries, the farmers will employ their own experts, not to take the place of the government specialist but to supplement and enforce the teachings of the schools.

5. To some extent an industry thus organized can control production, so that within certain limitations of climate and heat, a group of producers may be enabled to put upon the market the amount of product needed at prices that will give the majority of producers a reasonable return. Competition between regions in the same industry may be reduced, even if not eliminated. The orange growers of Florida and California; the apple growers of Oregon and Maine; the dairymen of Vermont and New York are competitors rather than coöperators. When each of these industries is fairly organized the country over, much can be done to reduce disastrous competition.

\section{A LOCAL UNIT IS THE BASIS OF GOOD INDUSTRIAL ORGANIZATION}

This statement is the alphabet of coöperative business organization. It virtually means the establishment of a coöperating group of farmers living fairly near together; in other words a community of farmers engaged in similar production. One farmer may grow half a dozen products; so consequently he will belong to half a dozen groups. A farmers' exchange may handle a variety of products, but it can do so profitably only as it is enabled to specialize in each product sufficiently to secure all the gains that come from concentration of effort. There is still an ambition on the part of those who seek the organization of farmers to do something big, to have a huge membership, to cover wide territory. For certain purposes, like influencing legisla- 
tion or dealing with huge corporate interests, a large overhead organization of farmers is necessary. The New England Milk Producers' Association is a widespread organization, with a large membership and an ample treasury, and has been a veritable godsend to the New England dairy farmers during the emergency created by the war. But the permanent effectiveness of such an organization among milk producers anywhere can be assured only when there exists a multitude of local dairymen's clubs or associations which, indeed, include practically all the individual dairymen in each community. The "local" is the strength of any associated effort. The local farmers' exchange, the local egg circles, the local apple growers' association, the local Grange, the local school, the local church - these are the very bedrock of permanent and effective organization of rural agencies. The overhead organization should not be composed of individuals but should be a union of federation of locals. Local unions may be combined into district unions (not on a county basis unless the county forms a natural marketing area), state unions and national unions. There may also be regional unions.

\section{ORGANIZATION FOR OBJECTIVES}

This is a very important phase of organization, although at first thought it may not interest the farmers. It means simply coöperative effort to reach some definite aim by bringing to bear upon it all the forces that are available. It may take the form of a "drive" for getting all the farmers in a certain apple growing region to spray fruit trees, or to increase production of a certain crop. Or it may be a little more ambitious, taking the form of what might be called a "development 


\section{I32 THE FARMER AND THE NEW DAY}

campaign" ; as for clean milk or for rural health. It is in reality a program for a definite goal that has to be participated in by a good many agencies and many kinds of services performed. For example, in a dairy campaign, there should be plans for scientific research, bringing up the quality of dairy cattle, or better methods of dairy farm management, or a system of milk distribution that is valuable to the farmer, or advertising the food value of milk. Proper laws should be passed and administered. No one agency could do all this work, for it is partly educational and partly administrative. It means a combination, on some well defined plan, of the milk producers' association, the milk handlers and consumers, the agricultural college and the farm bureaus, the state board of agriculture, and the United States Department of Agriculture.

It may be desirable also to organize the main fields of agricultural effort, such as production, distribution, country life, political interests, because each one of these groups has special problems and coöperative interests.

It is probably clear to all that in organizing for objectives there must be the leadership of some agency or group which will take the initiative in bringing together all the agencies that will play a part in the work. The whole program must be mapped out, an effort made to find out just what needs to be done, what each agency can do and how they will all work together for the common end.

\section{ORGANIZATION BY REGIONS}

Prior to our entrance into the war, comparatively little attention had been paid to the thorough organization of the food production in any given region as a unit. 
Neither in community, county, state or nation had there been a consistent food production program; but within a few weeks after war was declared, there came into being a multitude of food production committees. In nearly every state in the Union, probably in a very large proportion of the agricultural counties of the country and in thousands of local communities, these committees appeared. This organization by regions, illustrated in the war emergency plans, is perhaps the most important phase of rural organization and should be made permanent. The idea of regional organization has wide applications.

I. The Individual Farmer. No one needs to argue with the good farmer about the importance of organizing his business. Skillful farm management is the acid test of good farming and is probably to-day the big outstanding need of our agriculture as it relates to the efficiency of the individual farmer. American agriculture will be fully efficient only when every one of our seven millions of farmers becomes a good manager. Organization is the secret of farm management; it secures a union of forces in the most effective way to get the results the farmer wants.

2. The Farm Home. All that has been said in regard to the farm applies to the home. To those who have given the matter little thought, an argument for organizing the home may seem to be impracticable. It is not only practicable, but vitally important that each home shall do its share, serve its purpose, in the best way. This is not a mere private matter as some suppose, but one of the utmost consequence to the welfare of farmers and of the nation. The secret of a fine home is the right spirit and atmosphere; without these organization is futile. But in the best sense, organiza- 


\section{I34 THE FARMER AND THE NEW DAY}

tion, management, skillful handling are what make the home effective. Organization is not a cold-blooded piece of efficient machinery. Good organization takes into consideration the human factors, and in the home a large part of the management of organization consists in the tact and affection and vision of the home maker.

3. The Neighborhood. The National Council of Defense recently issued a nation-wide appeal for the organization of school districts which are virtually neighborhoods of farmers. Much good will come from this effort. But it is a very grave question as to whether so small a group as live in a school district or farming neighborhood can be organized effectively, although there is no reason why such neighborhoods should not coöperate in every way possible for their common interests.

4. The Local Community. Here we come to one of the most important matters connected with rural improvement. The organization of the local farming community is in some ways the biggest single enterprise for the farmer in the New Day. This is so significant that we shall devote considerable space to it. It means the effort to persuade all the people and all the local associations and agencies of the community to pull together for the common good. By "community" is meant that local area, not always clearly defined, which has or may have its own school and church and organizations, a region large enough to organize well and small enough so that everybody may become acquainted.

5. The County or District. It might be better, theoretically, if the natural farming districts could be set apart for organization purposes, based on the presence of a central market town. But the advent of the 
county farm bureau has probably fixed for all time the county unit of organized endeavor. The county has some advantages. There is a good deal of county patriotism throughout the United States. The county is the smallest effective political unit in most parts of nur country. The movement to organize agriculture on a county basis is making rapid headway.

6. The State. No state in America has ever developed a consistent and comprehensive agricultural policy or unified effort to get the maximum results for its agriculture. Yet that is merely the business-like thing to do. Each state ought to take stock of its resources in agriculture, of its possibilities and its needs, laying out a definite program for improvement, and then seeking to bring together all the different public and voluntary associations that will make the achievement of the program possible. It is strange that we have not done this before. There is now a strong feeling all over the country that this is the statesmanlike method and that it must be done if we are to get full effectiveness in our agriculture.

7. Groups of States. There are certain groups of states that have many things in common. The South, for example, both because of the likeness of its products and its historic unity, seems a natural region for coöperation. The New England states form a natural unit. The Rocky Mountain states have much more in common with each other than they have with any other part of the country, by reason of possibilities of irrigation and of dry farming. The so-called crop "belts" such as the corn belt, the wheat belt, sugar beet belt and the cotton belt, form less distinctive but nevertheless important regional interests. It would be a great gain to American agriculture if the whole country were di- 


\section{I36 THE FARMER AND THE NEW DAY}

vided into six or eight of these natural regions or zones in which the economic problems of the farmers are similar. This process has already developed in a partial way. For example, the South has unified her agricultural enterprises to a considerable degree. The South has probably made greater progress in agriculture in the last 15 or 20 years than has any other part of our country, and we believe it is due partly to the organized endeavors of the southern people as a group.

8. The Nation. This is the culminating form of rural organization as applied to a region. It simply means, as has been said before, that we should regard the seven million farms of the country as one big farm, and the seven million farmers as one big family. The farmer cannot play his part in the New Day unless American agriculture as a whole is thoroughly organized, with adequate policies and programs and with machinery for securing the coopperation of all concerned. This, too, will be the subject of a chapter by itself.

9. Urban and Rural. We must find a method by which the industrial and commercial interests of the city may strike hands with the interests of the farmers, through some form of organization which will place these two interests in the proper relation one to the other and secure their fullest coöperation.

I o. The $W$ orld. The idea of a world organization of agriculture is not new. Its first prophet was David Lubin, who planned the International Institute of Agriculture in Rome. The war has made imperative what to many before the war seemed like a dream. We shall be obliged to recognize the world's interest in the control and use of the land as a source of food supply. The land problem in Russia is the fundamental problem of Russian democracy. Russia is rural, of course; but 
the land problem in England which is urban is almost equally important. We can no longer think of agriculture in a purely national sense. The farmers of the world must meet the New Day in the spirit and effectiveness of world-wide organization.

\section{IS THERE A PLACE FOR THE GENERAL FARMERS'}

\section{ASSOCIATIONS?}

This is a question that will interest many thousands of farmers belonging to these great organizations. The answer is in the affirmative. There is no reason why organization that has broad purposes, high aims and aggressive programs should not have a most important place in rural welfare. But as the organization of sub-industries develop, it would seem as if the principles of these great organizations should be very clearly defined and every effort made to fit in to the activities of other associated groups. For example, if the wheat farmers and cotton farmers and stock farmers are thoroughly organized, just where will the Grange come in? Does not its mission lie very largely in the fact that it is a sort of fraternity, a family of families, comprising men, women and children, and that its educational and social teachings are probably its greatest assets? There is no reason, however, why the Grange should not play the part it has in the past - a great part in securing better conditions for farmers. So also with the Farmers' Union. And while the existence of the great farmers' organizations is highly desirable, there is no doubt but it is difficult, if not impossible, to have one inclusive farmers' organization. Our country is so large, the intermingling of the masses of farmers in the different sections is so nearly impossible, the special needs of the different regions differ so 


\section{I38 THE FARMER AND THE NEW DAY}

greatly, the presence of competing needs is so diverse, that an organization that would actually enlist in its active membership a large majority of our seven million farmers is practically out of the question.

\section{SHOULD WE HAVE AN AGRARIAN ORGANIZATION?}

By agrarian organization is meant a farmers' association designed to look after the special interests of farmers, possibly to resist the demand of other classes. In this sense, of course it is unfortunate that farmers have to organize. Such procedure incites class consciousness, develops a struggle for class interests. Nevertheless, if a great group of industrial workers like the farmers does not guard its own interests through organization, it is likely to suffer. It is possible, therefore, that there ought to be in America what might be called a fighting farmers' organization. But we are inclined to believe that the most effective fighting organization of farmers will be a federation of producers' organizations, for the reason that the producers will have very definite problems and difficulties. Each group, it is true, has its special interests to look after. Nearly all efforts on the part of farmers to influence legislation arise out of some economic need. Therefore, it would seem as if the organization which deals with the business of the great sub-industries would be the one best adapted to secure legislation. If questions arise that interest a large number of producing groups, the various producers' associations can act together.

CERTAIN PROPOSITIONS CONCERNING RURAL ORGANIZATION

I. Organization is the only way to full efficiency. We have had a planless agriculture. We find serious 
overlapping of activities on the part of different agencies. We find also serious overlooking of vital needs by these same agencies. Sometimes there is real friction, misunderstanding, and consequently a waste of time, money and effort in duplicated endeavor. Good organization would avoid these defects.

2. Rural organization must be of the coöperative, not of the military, type. German efficiency was real, but it was purchased at the expense of the individual. Coöperative or voluntary organization is not so effective in detail as the military or compulsory form, because all the people will not voluntarily coöperate all the time for all purposes. The only way to do it is by making an army of them. But there are manifest advantages in voluntary organization. The genius of democracy is coöperation and not compulsion.

3. Good organization does not submerge the individual; it enlarges him. It may subordinate him to the common good, and it ought to do so. It says that no one individual and no small group of individuals shall fatten at the expense of the rest. Organization recognizes that the individual at his best is the most effective force for the common good; that people are the vital factor rather than machinery or methods of organization. Organization seeks, therefore, to make each individual the most effective possible, but effective both for his own good and for the common good. Moreover, under ordinary conditions, the average individual can come to his best estate only as a part of an effective organization, so that good organization is really and fully democratic.

4. Organization eventually reduces rather than multiplies the number of associations, because it demands 


\section{40 THE FARMER AND THE NEW DAY}

the utmost efficiency of each agency and finds no place for useless effort.

5. Organization of the voluntary type can never be exact or complete, in the sense of a machine-like order or thoroughness, but it can be better than that, for it can inspire each man and each group to do its best for the common good in coöperation with all the rest.

6. All schemes of organization must leave place for new groupings, or soon we have a close corporation. Each new eifort to organize must justify itself by its effectiveness, by demonstrating that it has a mission to perform.

7. Collective bargaining is the most pressing single problem in rural organization at the present time. It has been often said that business coöperation in agriculture will come only as the result of dire necessity. This is true, but the statement needs qualifying. Necessity may drive farmers away from the farm instead of into coöperation; farmers may give up in discouragement rather than go to the trouble of organizing for business ends. It is possible, although still difficult, to organize farmers who are making a tair profit, if they feel that they are not getting a square deal and could do better by organization. Collective bargaining requires intelligence, confidence in the idea of coöperation, and complete loyalty - these must be added to mere necessity. One of our greatest difficulties in agricultural business coöperation has been that the abler farmers often hold aloof. Necessity is the mother of business coopperation. Is the new demand for an organization of the world's food supply a sufficient necessity to spur the farmers of America to thorough-going organization for collective bargaining? 


\section{ORGANIZATION}

8. The organization of country life interests is vital. Welfare is more than wealth.

9. All efforts to organize American agriculture should relate themselves to an effort to organize world agriculture.

I o. Organization is supremely in need of leadership, both the expert and professional leadership of trained specialists and the active, intelligent, aggressive leadership of successful farmers and their wives. 


\section{CHAPTER IX}

\section{THE MAKING OF RURAL COMMUNITIES THE COMMUNITY IDEA}

"We propose meeting together, talking together, buying together, selling together, and, in general, acting together for our mutual protection and advancement."

Declaration of Purposes of the Grange.

Tile spirit of this quotation, extended to all the people of a farming locality, is the community spirit. Togetherness rather than aloneness is the community idea. A true community includes the interests of every one living in the community - old and young, native and foreign, wise and foolish. The community idea assumes that every soul belongs to the democracy. It is based on the recognition of the rights of each individual, even the humblest, combined with the duty to neighbors that is the obligation of each, even of the strongest. But the community idea assumes more than that. It holds that the unit of interest is the common interest of all, not merely the combined individual interests of many. There is a vast difference between endeavoring to compromise the desires of a hundred individuals each seeking chiefly his personal welfare, and trying to bring the separate items of personal welfare into one program of common advancement - much the same difference that exists between bringing separate rings of iron into a pile and welding separate links into a chain. One is accommodation; the other is brotherhood. The 
core of the community idea, then, as applied to rural life, is that we must make the community - as a unit, an entity, a thing - the point of departure in all our thinking about the rural problem and in its local, practical application the direct aim of all organized efforts for improvement or redirection. The building of real local farm communities is perhaps the main task in erecting an adequate rural civilization. Here is the real goal of all rural effort, the inner kernel of a sane country-life movement, the moving slogan of the campaign for rural progress that must be waged by the present generation.

\section{BUT WHAT IS A COMMUNITY?}

It is not a neighborhood or even a hamlet. A mere collection of people dwelling in houses somewhat near together or within easy reach of one another does not constitute a community. Neighborhood life is important and neighborhood spirit vital. But a "neighborhood," as most American farmers understand the term, is not likely to be a true community.

The New England states teach us some lessons in rural organization. The "town"- or as it is better known in other parts of the country, the township forms a natural community. New England was settled by communities, or groups, or towns. When people decided to seek new homes they went as a community and formed a new town. Each town had its church and it is interesting to remember that the members of the church and the members of the political town had to be the same people. Each community had its school and its political or governmental life. Each New England town became a little democracy. It governed itself to a very large degree. It planned its future, paid 


\section{44 THE FARMER AND THE NEW DAY}

its own bills, managed its own affairs. Notice the use of the pronoun "it" not "they." For this town was a real unit, a sort of social person; it was not a mere collection of people, who happened to live near one another. Even to-day in the old-fashioned town meeting, the moderator - the presiding officer - announces that the town votes so and so or the town evidently wishes to do this or to do that. He does not say "the people of the town," rarely "the voters of the town," but " the town."

The Township as a Community.

The western township is an arbitrary affair, purely a matter of a survey, and has no relation whatever to natural groupings of farmers. In many cases the township has a substantial village near the center which if on a railroad forms the market and trade point for the people of the town. This village often becomes the real center of the township and makes it possible to have something approaching a community. In many townships there is no such center and the people find that their church life, the schooling of their children, their business interests, go in diverse directions. In such a case the township is not at all a community and it is difficult to make it one.

The Team Haul. It has been rather wisely suggested that the team haul might determine the area of a rural community, for the reason that the teams haul products to whatever center the farmers actually find most convenient; consequently, this center becomes a natural gathering place around which cluster at least the business interests of a group of farmers. The social and educational and recreational interests of a group of farmers, however, often lie out in the country, while their trading interests lie in some neighboring village or "town." 
The Consolidated School District. The consolidated school district seems almost the ideal area for a true community, not mainly nor perhaps even chiefly because we are to think of the consolidated school as the one community center, but because in the very nature of the case the consolidated schoolhouse will be so located as to serve the interests of that group of farmers who support the school and who therefore are rather accustomed or at least will soon become accustomed to thinking of themselves as having common interests. The location of the school is sometimes in the open country, but often in a small village; in either case, it is not at all unlikely that it may be found near a prominent church, Grange hall, elevator or creamery. The consolidated school district, therefore, forms more nearly a natural community area than any other district except the New England town.

The North Carolina Plan. A law has been passed in North Carolina which makes it possible for a group of people to organize afresh a legal community much like the New England town. The possibilities of this sort of legislation are extremely interesting, because such communities can be definitely planned and not left to chance.

The Practical Stcp. But how shall we really determine the boundaries of the local community? We have these various tests, some good and some not so good. As a practical convenience, we would urge the use of the township wherever there is nothing immediately at hand that is better. When the Grange was organized fifty years ago, it had to face just this question - what should be the "jurisdiction" of the local or subordinate Grange? The plan adopted was generally to take the township as the unit. Departures have 


\section{THE FARMER AND THE NEW DAY}

been made from this principle, but as a rule it will be found that a subordinate Grange draws its members substantially from a single farming township. This plan has worked well and if it serves the Grange, it ought to be satisfactory in the larger coöperation which is to be found in the organization of a real rural community. Where a township cannot well constitute the area of a community, it can be made by mutual agreement, acting through county farm bureaus or some other overhead organization. The main thing is to set apart a region or an area big enough so that the farmers having similar interests may maintain those interests as a unit; so that they may have their own churches, their own schools, their own business agencies. Yet this community must be small enough so that the members of the community can all come together, not occasionally but frequently, to discuss their common interests and to enjoy themselves as one big family. A community can be in a measure self-supporting. It may stand on its own feet. It may learn to act as one man in common concerns. Therefore, it must not be so big as to destroy this common interest nor so small that it cannot support the organizations and agencies through which society is accustomed to work.

\section{COMMUNITY METHODS IN RURAL DEVELOPMENT}

The individual farmer does not lose his identity through the application of the community idea, for it has nothing in common with "communism" or "collectivism " or "socialism" as those words are ordinarily understood. It is simply a more intensive and better developed form of rural coöperation than we have ever known. It takes the idea underlying the Grange, the coöperative idea that is the foundation of all our 
great farmers' organizations, and applies it to all the people of a natural group, not merely to a few selected members. Therefore the community idea can be applied to nearly every aspect of the work and life of farmers.

\section{THE COMMUNITY IDEA IN PRODUCTION}

Farmers are in the habit of talking of their plans, of exchanging experiences, of discussing new methods, of aiding one another in times of labor shortage. Now let us press this practice a little farther, organize it a little more completely, and we shall have the community idea applied to production. Thus we can "socialize" production. All students of the subject agree that we would make a great gain in our agricultural production if we could localize and standardize production. Can we persuade the farmers of a given natural community to grow just what they can grow best, and to grow nothing else, to grow the best of the kind that can be grown and of fairly uniform character and quality? If this were done, the land of the community could be better adapted to the crops; the best methods could the more easily be adopted because all the farmers would seek exactly the same ends. This localizing of production takes advantage of the habits and tastes of the farmers of the community, the traditions of their farming skill and makes use of all their experience. Community production is not widely practiced, but it is by no means an entirely new or theoretical subject. For instance, a community in Wisconsin ships many thousands of dollars' worth of Holstein cattle each year through an annual sale. The Holstein breeders' association pays for the advertising. The purpose of the breeders' association is to improve the native cattle by 


\section{I48 THE FARMER AND THE NEW DAY}

the use of pure bred sires, all of the same breed, and also to put their business on a more substantial basis through coöperation. It has educational advantages as well as enabling breeders to coöperate in buying and selling. The development of many of the great breeds of pure bred live stock owe their origin and development to community breeding. This is true of Jersey, Guernsey, Ayreshire and Holstein cattle and Percheron horses. The methods of apple growers of Hood River Valley, of the Rocky Ford melon growers, of the potato growers of Greeley, Colo., are all illustrations of the advantages gained when an entire community devotes its energy to that definite line of production for which it is best adapted. This principle is recognized by manufacturers, and we have shoe cities and automobile cities and jewelry cities. It is difficult to exaggerate the advantages that accrue when a community of farmers sets out to bring production to this common basis, each farmer seeking to do his best and all working together along a common line. Community production does not mean that a given community will grow only one crop - it will grow whatever crops can be best grown in that community, but whatever it does grow will be pushed to the limit. Standards will be set up. Quality will be sought. There is a common purpose and a common gain.

Farm Management. Even in the matter of farm management - apparently a very individual affair the most significant results come from an effort of a whole community to improve methods. Extension workers in farm management have already found that if they make a survey of all the farms in the community, they will find that certain farms are below the averace in their labor and income. This is the significant point. 
The farmer, like other people, is obliged to think in terms of his immediate surroundings and experiences, and if he finds that he is running behind the general average of neighboring farmers, he realizes that there is probably something wrong with him. This definite community of experience aids the less efficient to become more effective without in any way pulling down the more efficient. It helps to bring all the farmers to a higher level of effectiveness.

Seed Selection. The individual farmer can, of course, select his own seed, but is more likely to do it carefully if there is a sentiment in his community which demands of each farmer the selection of the best seed and its careful testing. Indeed, a community of farmers may well select one of its number who is skilled in such matters to select and test seed corn for the entire community. If this principle were generally applied, we would soon find a great group of farm experts living right on the land and serving their local communities in a most practical fashion.

Use of Power. One of the greatest handicaps of the average American farmer, has been the absolute necessity of his making an increasing use of machinery and the relatively enormous expenses of getting it. Farm machinery has become indispensable and yet every business farmer as well as every authority on agricultural economics deprecates the large expenditures which farmers have to make for expensive machinery, most of which is idle for eleven months in the year.

The theory that farm machinery can be owned cooperatively and used coöperatively often breaks down in practice. There are many difficulties, but there is not the slightest doubt that greater efficiency 


\section{I5O THE FARMER AND THE NEW DAY}

could be gained if communities of farmers would plan together for the most effective use of machinery. It is very likely true that one farm tractor will do all the work for a half a dozen farms. Certainly one threshing machine will do the work for many farms. It is not necessary that the community as a business corporation should own and control this machinery, although even that is not merely a dream. But it can at the very least decide as a community that it will economize in farm machinery, and the community, as a unit, can make a contract with an individual to do the threshing of the community, or with several owners of tractors to do the plowing for the community. These things are actually being done here and there. They simply need to be organized, systematized, to get the greatest efficiency.

Power. Farmers were using power generated by gasolene to an extent unbelievable a few years ago. In the future, the use of electricity upon the farm will prove one of the great gains that the years will bring. But it is doubtful whether the farmers can get electric power as cheaply or as generally as they ought to have it if they treat the matter purely as an individual concern. In some cases, power can be developed by communities; at the least the community as a unit can make far better contracts for power than any individual can make.

Labor. The labor problem in the United States, serious before the war, has become acute. It will be one of the farmer's greatest difficulties for many years to come. The individual farmer will employ his own labor and manage it. Yet the labor supply for agriculture will be more and more a matter of organization, 
of successful competition with other industries, and therefore it will have to be treated more and more as a community affair. There is no other way out.

Accounts. It may appear rather chimerical to some, but we may find the community idea extremely successful in a field that at first seems to be purely a question for the individual farmer, namely, that of keeping accounts. Theoretically, every intelligent farmer believes in the value of a good system of bookkeeping and accounting, but nine out of ten of these same intelligent farmers find it an extremely difficult thing to do. The time, the labor, the annoyance involved in any thorough system are almost prohibitive. Why not put accounts on a community basis? The community accountant might be an employee of a local bank or the business agent of the local coöperative system, or a farmer's daughter who has the training and the time. Rules safeguarding the privacy of accounts could easily be made. The farmer would turn in his slips of record and results would be tabulated and returned to him. When divided among a community of reasonably prosperous farmers, this would not be at all an expensive affair. What is referred to here is not so much the routine business connected with buying and selling and paying bills - the private accounts - as it is that form of accounting which determines the profits or losses of the farm business as a whole or of any part of it. True accounting, as applied to farming, means a method by which the farmer can account for or understand what is actually happening to him as a business man. The principle is good everywhere and for all kinds of farm business. 


\section{THE COMMUNITY IDEA IN DISTRIBUTION}

It is not necessary to take so much space to discuss the community idea in distribution as it was in the case of production, because most farmers have the feeling that it is impossible to coöperate effectively in production, whereas they are fast learning not only that collective bargaining is essential to agricultural profit but that the local farmerc' exchange or coöperative society is the very core and center of successful business cooperation. This local group of farmers constituting the farmers' exchange is practically a community from the standpoint of business.

Selling the Product. Efficiency in selling farm products requires first of all a standardizing of goods. This is gained through some common high standard of quality, through the use of best varieties, proper grading, and scientific, honest packing. Successful fruit growers often have individual trade marks, but the device has been adopted by very few individual farmers. Each community that specializes in its products can have a trade mark, and a trade mark that is a guarantee of quality is worth more than any other single item in the sale of any commodity; but the great need is for collective bargaining in making sales. The old Kansas farmer who, as the story goes, held back his wheat in order to corner the market and bring a rise in price was just as successful as any other farmer who allows himself to become, as an individual, a bargainer with a great organized market. It is not necessary to put the middlemen behind prison bars in order to get justice at this point; it is purely a matter of better business. A farmer with 500 bishels of potatoes to sell certainly is at a disadvantage as compared with a community 
with 5,000 bushels. The buyer who can afford to disregard the individual with his small crop cannot ignore an entire community. $\mathrm{He}$ is willing to make terms with a community when he would browbeat the individual.

The Core of Cooperation. At the risk of repetition, let it be said once more that the local community is absolutely the only possible foundation for sound business coöperation in agriculture. One of the wisest and most successful leaders in business coöperation in this country says on this point:

"It is fundamental that the unit of each agricultural industrial organization formed to distribute and sell farm crops or for other business purposes must lie in a comparatively small area. The members must be well acquainted with each other, their aims must be similar, and they must grow products of similar quality and character if they are to succeed when associated with one another. It is equally important that the membership be a stable one and that the farm lands are not frequently changing hands, a condition which often operates against the success of the coöperative movement in the newer sections of the country. If the products vary widely on account of differences in the soil, in climate, or other environmental conditions, the grades are not uniform and the producers cannot easily be held in a common organization. The efforts that are frequently made to have a single organization cover a wide territory are, therefore, not likely to succeed. It is desirable from every point of view that each rural community and each individual should retain its individuality to the greatest possible extent, that it should not have local pride and ambition stifled by too general a mixture with other sections, and that it should be encouraged to build up a local reputation for its products that distinguishes it from other communities." 1

I Powell, G. Harold, "Coöperation in Agriculture," pages 19-20, New York, 19r3. 


\section{I54 THE FARMER AND THE NEW DAY}

All the European experiences in a dozen countries for nearly half a century of successful business coöperation are a demonstration of the same fundamental practices. That is the rock on which the early efforts at business coöperation in America foundered, and unfortunately many enthusiastic and right-minded friends of the farmer and even farmers themselves, still have the vision of a great comprehensive scheme of business coöperation by which thousands of farmers, acting as a unit, can by the very pressure of numbers and power, make successful bargains. Every such effort breaks down of its own weight unless it is founded upon a multitude of little pillars, each pillar a solid block consisting of a well managed local unit.

Some Well-known Illustrations. We ought to learn our lesson from the varied experiences of many institutions. Probably there is not a leader of the Grange or Farmers' Union leader in America who does not admit that the local is the strength of the organization. All overhead machinery in the form of county or state or national organizations is an attempt to conserve and strengthen local effort. All coöperative power springs from the local organization and flows back to it. The same is true of the country church, of the country school. The strength of these institutions is to be found in the local church or in the local school. We may have a great church organization or a great rural school system, but it is a rope of sand, in either case, except it be composed of successful local efforts. We need the federation or union of locals for the sake of large policies and unity of endeavor, but the actual work is always done by the local.

Community Industries. plied to local industries.

This idea may be also apThere are many farming 
communities, especially those containing villages, which should be closely knit with the farming region, and which would be greatly advantaged through the development of certain local industries. It is not unthinkable that the labor supply in some regions may be secured through the development of such industries as electric power, employing labor which will be available for the farmers during the summer. Certain small manufactories use up the surplus or otherwise waste products of the neighboring farmers and thus are an advantage to everybody. But these things have to be planned for and, as a rule, this will be done only when the community as a whole takes action.

Rural Credit. Credit may be made largely a community affair instead of merely an individual matter. Probably the one outstanding fact gathered by the American Commission which went to Europe in I9I 3 to study agricultural credit and coöperation, was expressed by the former Premier of Italy, Luzzatti, when he said: "We have capitalized character." That is, a community of farmers of very moderate means, if they know one another and are willing to back one another, can borrow a great deal more money and on far better terms if they act together, than the different individuals in that community can do if each acts alone. There is an irrigated valley in the West in which the farmers own property probably worth ten million dollars. Yet each individual is obliged to borrow money on the best terms he can get as an individual. The farmers of this valley are really or may become practically a unit, a corporation. As such, they should be able to borrow strictly in accordance with good business terms all the money they need for improvements or for making the crops. They can do it only as they 


\section{I56 THE FARMER AND THE NEW DAY}

form a real community. They must act together to the last man. They must be willing to pool their business interests, to take some business risks togelher. Probably American farmers will be rather slow in applying this principle but it is fundamental, nevertheless, and lies at the foundation of a permanent system of rural credit, which in turn is almost essential to a permanent agriculture.

SOME OTHER APPLICATIONS OF THE COMMUNITY IDEA

The farm community may produce its own supplies to a considerable degree. It may partially feed itself. It may build its own houses, make its own furniture, have its own laundry, can or preserve its own surplus fruit, produce its own butter, meat, eggs and poultry, bake its own bread; it may even do its own sewing! Now the question whether the community will do these things or not is purely one of economy. If it is cheaper to buy outside of the community that should be done, if it is cheaper to manufacture and buy within the community, that should be done. The whole idea is what is best for the community, and whether a group of five hundred or a thousand people will choose to do its own business. A community can determine whether it is properly served by its merchants and its blacksmiths. Why should not a community decide on service of this sort as well as on its school teacher or its preacher or its political agents? Some industrial communities have a community physician; why not a rural community? The houschold activities may sometimes yield themselves to the coöperative idea. A community kitchen has been maintained in Montclair, N. J., for some years. Would it be practicable in a farm village? Three or four coöperative 
laundries have been in operation in Minnesota and Wisconsin long enough to prove the feasibility of the plan.

\section{COMMUNITY PROTECTION}

Nor have we yet exhausted the possibilities of the community idea. We still, to a considerable extent, leave the individual farmer to protect himself against unfavorable conditions. He fights his own potato bugs and tries to defend himself against the blight. But effective protection is almost wholly a community affair. Not many years ago, a law was passed in some western states compelling farmers to spray against certain diseases, and why? Simply because the failure of a single farmer to combat a pestiferous insect or a contagious disease of his trees made him a menace to all his neighbors. The whole thing becomes a community affair. The spread of weeds is very serious in some regions. It is possible because we still treat the matter as a concern of the individual farmer. But the injury falls upon the entire community of farmers. A noxious weed law in $W$ isconsin requires that every property owner destrcy certain weeds if found on his land.

THE COMMUNITY IDEA APPLIED TO COUNTRY LIFE

The Education of the Rural People. The school is perhaps more completely a community institution than any other agency of rural endeavor. For decades, and in some parts of the country for generations, its maintenance has been a community charge. Every family has participated in the cost and every family has felt free to participate in the advantages of the school. But the rural school has failed thus far to measure up to its full capacity as an educational institution, both 


\section{I5S THE FARMER AND THE NEW DAY}

in its point of view in the teaching of pupils and in the narrow range of its influence upon adults. John and Mary have been treated as individuals; the instruction has had comparatively little regard to the relationship of John and Mary to other folks, and yet it is the relations of life that constitute its problems. Teaching the pupil to think is good, but to think about what? Himself? His own interests alone? Or his obligations to other people, the common good and interest? It is well for the school to give knowledge, but what sort of knowledge? The knowledge that has to do only with profit and loss? Shall the school not seek to impart a love of the beautiful in literature and art? Shall it not also give the knowledge of what races and nations and communities have done and are doing and want to do? Moreover the average citizen has never thought of the school as intended for any one except children. It took a long while to persuade our people that the high school should be maintained at public expense. In some parts of our country to-day, there is no public opinion in favor of the publicly supported college or university. So when we begin to talk about the relation of the school to the adult people of a rural community, we are not understood, and it is doubtful if the old-fashioned district school with its meager equipment, its one room, its poorly paid teacher, can do very much for the adults of the community. But a consolidated school, with several teachers, a properly trained principal interested in rural affairs and remaining in the community until his leadership is proved, a school house with an audience room that will seat the people of the community - give us these and then we begin to see what the school may do for the adults. And what may it not do? Our idea of the education 
of the rural people (and this is just as true of people in the city) is that they shall be perpetually at school. Our aim should be nothing less than a scheme of education, centering in the rural school, utilizing all of the organizations and agencies of education whose aid can be secured, even after school days, to keep on studying and reading and thinking about the problems of their community and of the world. This vital application of the community idea to the education of the rural people is of the utmost importance.

The Home. How can the community idea best be applied to the home? In spite of the fact that the home is so personal an affair and must retain its privacy, no home is a true home until it has developed a proper relation to the community. No family can live unto itself. The ideal community is a group of families that form one big family. In the ideal home we have the divers interests and capacities and tastes of each member of a family of two or a dozen, as the case may be, all merging into a common interest. So in the ideal community, we have the tastes and ambitions and interests and capacities of all the members of the community merged into a common interest and ambition. In the home perhaps better than anywhere else can be taught just these ideals. Indeed if they are not taught and practiced in the home, they will make slow headway in the community. So that the application of the community idea to the home becomes one of the great ideals of our rural life.

The Church. The country church has had a wonderful history and has done a wonderful work. In the pioneer days it saved our American country life from sordidness and materialism. The preacher and the pioneer farmer went west together and together 
they endured the hardships of that early life. Nevertheless, the local country church to-day usually regards itself as an end in itself. If you belong to the church, well and good; if you don't, well and worse — from the church point of view. Those in the church are saints; those without are sinners. The success of the church is measured quite largely by the number of its members and the hum of its machinery. But every now and then we find a country pastor or a country congregation that has torn itself away from any such restricted notion as this, and has come to understand what Jesus meant when he remarked: "He that loseth his life, shall find it," and that he referred to groups of Christians as well as to the individual Christian. In other words, when the church thinks chiefly of itself, it grows weak and ineffective. When it thinks chiefly of becoming a pathway to glory to all within its fold, it shrivels. But when it becomes a ministering agency of friendliness and neighborliness and good will to the entire community, then it lives and grows and vitalizes the spirits of men. It is not putting the matter too strongly to say that the country church will regain its leadership in rural affairs only when it applies the community idea to its motives and methods.

The Health of the Community. Health should be regarded as decidedly a community asset. It is always the individual who is ill, and so the knowledge of home care, food and home nursing should be more widespread. But disease really affects the whole community. It reduces the working power of the community through loss of time and money. The untimely removal by death of a strong member of the community produces a loss that the community may never get over. So the teaching of personal hygiene as a part of com- 
munity education, methods of prevention, the futility of most patent medicines, are all matters of importance. But they are best taught on a community basis, so that they become a part of the common knowledge of the community. In the preventing of the spread of communicable diseases, the community idea is absolutely essential, because public opinion must be brought to a point where it will acquiesce in health regulations and indeed insist that individuals comply with them. There ought to be in every rural community health study clubs or rural health leagues. There should be a health program for the community. Unhealthful places should be cleaned up, a public nurse should be provided. Wherever possible there should be a health center and a public clinic. The time is not far distant when communities may be expected to employ their own physician who will be a preventer rather than a curer of disease. In more populous rural communities, especially with the village at the center, community baths are not without the possibilities. The community hospital, or at least a hospital service for a group of communities, will soon become an essential in country life.

The Community at Play. Farmers desire recreation just as much as other people and enjoy it just as much, and in the better farming communities there is a vast deal of wholesome recreation for both the old and the young. But every investigation that has ever been made on this subject has revealed the fact that as a whole, farmers actually do not play enough. Recreation is a social affair. It is impossible to play alone. It is difficult to get very much recreation any great distance away from home. Thus the play of the children and the social life of the older people become very distinctively a community affair. How can play better be 


\section{I62 THE FARMER AND THE NEW DAY}

developed in the rural community? For the youngsters the school is the natural center of play life, partly because that is where children are and partly because the right sort of play is good education. Some boys and girls learn as much through games as they do in school. The Y. M. C. A. and the Y. W. C. A., the Sunday school, the Boy Scouts and the Camp Fire Girls all have possibilities in developing play that is organized and yet not artificial. In the small or scattered rural communities, it is difficult to maintain an adequate play life for the youth who have perhaps left school and have not yet joined their elders' socials. Perhaps the Y. M. C. A. and the Y. W. C. A., working in the country districts as they do, are more likely to work out this problem successfully than any other institution. But these agencies work on a community basis; they bring together the young people of the larger neighborhoods. They do not deal very much with the individual alone, on the one hand, nor with big scattered groups on the other. For the older people, the church and the Grange or similar organizations make an outlet. The chief difficulties are not so much in agencies as in difficulties of getting together. It is here, of course, that good roads have a part in the right sort of community life. The community should make recreation a part of its program - community picnics and sociables; the keeping of holidays and celebrations by the entire community; the community paper; the community drama, developing the theatrical talent of the community; community musicals, the natural inheritor of the traditions of the old singing schools; community excursions to the state agricultural college of the nearby city or the state fair; the community motion pictures or at least community oversight of the motion pictures; 
the entertainment course, adapted to all the people of the community; community sport or play days for old and young; inter-community contests of various sorts, athletic and intellectual; how much richer life will be wherever a community decides to have such a program of recreation.

The Community Beautiful. Nature has done her part for the country. Unfortunately man has often done his part to spoil it all. Straight highways, square corners, the absence of shade trees, unsightly weeds, unkempt door yards, box-like houses are altogether too common in our American country life. It is possible without great expense to develop a set of beautiful communities in the country side. We need a rural architecture, simple but charming. We may locate farm buildings so as to render the plant both convenient and attractive. The use of fruit trees as well as of shade trees in the highways; the development of parklets or squares in the country villages after the fashion of the old New England village common; the proper location, architecture and landscape surroundings of such buildings as the school, the church, the Grange hall, the town hall, the library and the community house are possibilities within the reach of multitudes of farmers, once public opinion of the community insists upon it. If these things cost a great deal of money, perhaps they might not be so strongly urged, but it is largely a matter of community enterprise and education and insistence. There are plenty of farmers and farmers' wives who want these things, but they have to treat them as individual matters. They must now set the community to work to get them.

The Socializing of Rural Morality. What is meant by this? Simply that we can no longer consider the 


\section{I6. THE FARMER AND THE NEW DAY}

wrong doing of an individual as merely his own affair. $A$ bad man is a plague spot in a community. Thousands of men would almost give their right arms if they could have avoided in youth certain contacts with men who were not clean. We have been too tolerant of $\sin$ and too intolerant of the sinner. We must reverse our scales and contend the evil by extending a friendly hand to the repentant. But what can be done in the rural community? Well, if every wrong were to become a community affair, it would be easier to enforce the law. At present, it is difficult to enforce law in the rural community because enforcement is such a personal affair between people who know one another. But once public opinion demands right doing and the officer of the law knows that he is representative not of his own authority, but of the community, he will be obeyed. Then too rightness can be made a fundamental article in community program. Unify the religious and moral forces that abide in the church, the Sunday school and the rural Y. M. C. A. into a combination of high ideals and practices. Lay the foundations for good morals by clean sport for the young and healthy recreation for the older ones. Make morality redblooded. Banish the long-faced preacher and elect no man a church deacon unless the boys in the church nominate him. Hold aloft the ideal of a righteous community. The life of the rural people is the most important part of the rural problem. Therefore it ought to be the concern of every rural community to see that in education, in home life, in church life, in health and recreation, in beauty and convenience and morality, high ideals are maintained and practiced and continuous steps taken to build up the sort of life that the best people at all times and all people in their best moments acknowledge as half of the great end of living. 


\section{CHAPTER X}

\section{ORGANIZING THE RURAL COMMUNITY}

\section{THE OBJECT}

THE main object of organizing the rural community is to try to secure the coöperation of all associated effort and individual influence on behalf of a generally accepted plan or program for improving the community at all points. By reason of such coöperative endeavor, should emerge at last a group of people with one mind as to the desirability of working together for one large purpose and in the finest spirit of coöperation. Remember again that organization is merely the coöperation of all the people. It is an assembling of all factors that make for better working and living together. It implies a group of people working as one. The ideal is the most complete possible coöperation of all individuals and all groups in a small natural area, making their best efforts in the common task of securing the greatest possible improvement in all things that make for the common good.

\section{THE FIRST STEPS}

There must be some new "machinery" for the purpose of this organization, otherwise it is difficult to draw out leadership in community enterprises. But few communities need a new organization. Indeed, what is wanted is not an organization at all in the usual meaning of the word, but rather a clearing house for I65 


\section{I66 THE FARMER AND THE NEW DAY}

existing associated effort, a "round table " on the best ways of developing the best interests of the community and how each agency and each individual can best help. The start may be made by any person or any group of persons that is so minded - the Grange or master of the Grange, the school superintendent, the church or the pastor of the church, the farm burcau or the farmers' club. It makes little difference what particular form of organization shall be developed.

It is, of course, necessary that at the outset there should be meetings of citizens to discuss the question of community organization. The whole matter should be carefully explained by some one who really knows about it, so that the community idea may be perfectly clear at the outset. Beyond that, no hard and fast method of organization need be urged. Experience has shown, however, that there are some plans worth adopting if best results are expected. They comprise the following and each will be discussed briefly:

I. The Community Council.

2. Gaining the Facts.

3. The Community Program.

4. The Community Meeting.

5. The Community Center.

6. The Community Goal.

\section{THE COMMUNITY COUNCIL - THE ONE ESSENTIAL}

It is practically impossible to build a true community and develop its activities fully without some sort of central group which in some way represents the entire community and all its interests. The name applied to this group does not matter; it may be called a community committee, a community group, a community federation, or what not. "Community council" is a 
term that seems best to convey the complete purpose and task of this central group. No one club or association or institution can do all the work that needs doing in a community, nor can it possibly represent the entire community. Whether there are two agencies or twenty in a community, there is the same need that they shall coöperate for the common interests of the community.

The Make-Up of the Council. There are two principles applying to the organization of a community council. It is desirable that each agency in the community shall be officially represented, the Grange or Farmers' Union, the farmers' club, each church, the school, the woman's club, even the fraternal organizations may be admitted. It must be understood that what we are seeking is to "speed up " or increase the efficiency of the work of each existing agency, not to deprive it of its work. Consequently each should play a part in the general plan. That is just what community organization means - to bring together existing forces, not to make a new machine. If there are not very many agencies in the community, a council having half a dozen to fifteen members will represent them all very well; if there happens to be a larger number, then the council may be larger. The other principle is to make sure to have in the council the natural leaders in the community. These leaders may not always be officials in the different agencies nor the chosen representatives of those agencies. So it does very well to add to the council from three to five members at large. It is well to have a constitution and by-laws, models for which can be obtained as a rule from the extension service of the state agricultural college. 
Committees of the Council. There are four committees that seem to be necessary in order to cover the main interests of a community, as follows:

I. On production.

2. On marketing and other business interests.

3. On conservation.

4. On community life.

But there may be as many sub-committees as there are problems, covering such interests as good roads, farmers' exchanges, recreation, education, community planning, health and sanitation, local government and so on.

The Actiritics of the Council. The task of the council is to confer, not to direct or manage. It should consider such questions as these:

I. A community study.

2. A community program.

3. The work of each agency in carrying out the program.

4. Community meetings and conferences relative to the program and its progress.

5. The need of new association.

6. Bringing the community into touch with other communities and with county, state and national activities.

The Community Secretary. It is desirable to have a community secretary. The ideal, possibly, would be the employment of a person who could give full time to the interests of the community. But this is hardly possible in most rural communities, and there are, no doubt, cercain advantages in having not a professional community manager but a voluntary worker who gives frecly of his time and energy and thought. This official would probably be the secretary of the council, chosen by it to serve as its executive agent. Choice 
may fall upon the master or the lecturer of the Grange, upon the pastor of the church, upon the superintendent of schools or the principal of the consolidated school, or upon the person who teaches agriculture in the school. The community secretary becomes a sort of community engineer. He studies the needs of the community and what other communities are doing. $\mathrm{He}$ brings these needs to the attention of the council. He endeavors to see that the different agencies are carrying out their program, tries to discover whether the program is working. He puts fuel under the boilers. He would naturally represent the council at county and state conferences. Here is literally a new profession opening up in country communities. But let us not be alarmed at the extent of his duties. There is not a farming area in America which has not some one in it who already does many of these things. We need to systematize and organize more fully and to be more definite in our purposes and plans. This community secretary will be a tower of strength in accomplishing results.

Community "Pace Makers." We are indebted to Minnesota for suggesting a unique phase of local community leadership. Not only do we want a community secretary, but we want some one in the community, chosen by the community, who is the recognized leade! in some one field and who will take the responsibility for endeavoring to push that interest in the community. One man may be a corn expert, another an apple expert, another a stock breeder, another especially interested in schools and education. There will be, of course, women pace makers for household management, child training, home decoration and so on. There should be as many pace makers as there are 


\section{I70 THE FARMER AND THE NEW DAY}

problems. Each one will make a study of the question, keep abreast the times, confer with specialists, read and study and lead discussion clubs on his particular subject and in all possible ways endeavor to lead the community to maximum improvement.

The Community Council a Planning, not an Achieving, Body. There is always a temptation when we get a new type of organization to judge the results wholly by the activities and achievements of the organization. So the community council will be tempted " to do something " in order to justify its existence. But to do something is not the job of the council. Its task is to get others to do the right thing in the best way for the interests of the whole community. It plans but it does not execute. It secures team work. In some cases, it may be necessary for the council or one of its committee to supervise a definite piece of work, but it ought never to do this as long as there is some other agency that can do it. We may be sure that a community council will have plenty to do in keeping the community idea alive and growing and in seeing that the community program forges ahead.

The Community Council Independent. A community council would be an absolute failure if it were the property of any local organization or of any farm bureau or of any school system or of any agricultural college or of any other overhead agency. It is the property of the community, appointed by the entire community, responsible only to the community. Of course the council should coöperate with all agencies outside of the community that can really help, but it cannot be managed by a county council, a state council or any other body. It is the free agent of a free com. munity. 


\section{GAINING THE FACTS}

Before a community can make a plan, it must know the facts about itself. What are the needs of the community? What are the best things that exist in the community? What are its resources, natural and human? What are the possibilities of the community? So we need first of all:

$A$ Community Inventory. The community inventory is just a little self study by the community itself. It brings together in orderly form the knowledge and the insight of the people themselves about themselves. The modern farmer who buys a new farm considers it essential to have a definite plan of development and of management. But he knows that a prerequisite to the information of that plan is knowledge - knowledge of the farm and of the market, of the type of soil, the history of the farm, the climate, the roads. All these are factors in determining his plan. He must know his farm. So if a farming community decides to make itself the best possible community, the prerequisite is knowledge - it must know itself. What are the natural resources of the community; how have the resources been used; what are the possibilities of improvement? Is the farm life all it ought to be? Wherein is it strong and wherein deficient? It is not necessary to presuppose that the community inventory means the existence of a "sick" neighborhood. Knowledge is indispensable to efficiency, and desire for greater efficiency is no sign of decrepitude. The desire of the farmers in any neighborhood to study themselves, as a starting point for developing a better community, is an indication, not of decadence, but of vitality. Only the "live" man desires to improve. 


\section{THE FARMER AND THE NEW DAY}

Only the community with life enough within it to possess a "divine discontent" with present conditions, no matter how good they may be, is the community in which one likes to reside.

The Communily Suldy. It may be worth while to ask the farm bureau or agricultural college to send specialists into the community for the purpose of helping to map out a community program by studying rather fully the resources, needs and possibilities of the community. If each community would do this, after a time it would have a program covering all aspects of community improvement based on full knowledge of conditions. This is the ideal. Such a study would do more than reveal conditions. It would inspire progress. Live people do not need much preaching. Their best inspiration to improvement is a vision of needs. Once a good farming community realized its deficiencies as well as its resources, it would insist upon a plan for improvement. Community study leads at once to community-consciousness, a community program and community effort.

\section{THE COMMUNITY PROGRAM}

When a community knows the main facts about itself, it will develop a community policy and a community program. The possession of a policy simply means that the people of the community have decided the direction in which and where they want to go; the program consists of the successive steps that must be taken in order to arrive. The community program covers the whole field of the community problem, what improvements are desirable and how they can be brought about in farm production and management, in farm business, and in community life. The program 
will be based on the community inventory, supplemented later by the fuller expert study. The program lays down the practical steps necessary in order to carry out the aims or policy of the community. It will deal with the steps necessary to make what might be called the ideal community, but it will be very practical and take up even minor matters of reform. The program must grow out of a coöperative agreement adopted by the committees of the council, by the council itself, and finally accepted by the community at a conference.

The council will assign tasks to the different agencies. Existing institutions must do the work if they can, but new agencies must be developed if they are necessary. If possible, needless agencies will be eliminated. There will be also a checking-up of results through frequent reports of the different agencies and from the committees of the council. It is important to develop and maintain study clubs or groups perhaps of only three or four people, and it may be of 25 or 30 , each group to take up some local problem and study it in the light of general principles and of outside movements, and particularly its application to the community. Here is the chance for the "pace makers" and here is the chance, too, for the local school, as well as for the extension service of the agricultural college. The work of the farm bureaus and of the extension service of the college, indeed the work of all educational agencies, should fit in with the program and need of the particular community. All educational machinery should be geared to the policy and needs of the community.

The community program is designed as much to arouse community will as for anything else. Hereto- 


\section{I74 THE FARMER AND THE NEW DAY}

fore, in seeking community improvement, we have been content with the scattered efforts of various agencies. Now what we want is to have the community as a whole act and plan for itself. But it cannot do this unless it has the will to do it and to keep at it. A plan that everybody can understand and discuss and have a part in, helps to develop and strengthen the community will.

\section{THE COMMUNITY MEETING}

The New England town meeting is the most democratic institution of the American government, because it calls together the people of the community to talk over their common interests. In the old days, it was decidedly a community meeting because it dealt with all of the interests of the people. Gradually, it became purely a political or governmental meeting and so is restricted in its operations. It deals only with those affairs for which public money is to be expended. But we need everywhere frequent community meetings for the discussion of all these common needs and purposes of the community.

Regular Meetings. Community meetings should be held regularly at least four times a year, or better, once a month; perhaps in some communities during a part of the year they could be held as often as once a week; but it is vital to bring the people of the community together rather frequently to confer about their common welfare.

Definite Objects. There is little good in meetings of a general character, certainly no good at all in meetings for the sake of a meeting. There must be something worth while to discuss, such as the big problem of community organization; the items in the community program; reports of progress in the community pro- 
gram; reviewing the program from time to time; and finally subjects of general interest. This last need leads us to recommend:

The Community Forum. The community forum is the gathering of the people of the community to listen to and question a speaker who is supposed to have a message about a matter of national or world-wide importance. The forum takes the place of the old country lyceum. It is not a lecture club in which the orator is expected or obliged to amuse or please the audience. It is a discussion. There must be question and answer. It is a great school of democracy when properly handled. It can be developed as a part of a community council, although there is a recognized forum organization in existence. In the country districts, however, we do not want to multiply machinery, and there is no good reason why the community council could not make the community forum a regular part of its service to the community.

The Community Conference. The community conference is simply one form of the community meeting and in smaller communities will not be needed. Ideally, the community meeting is a meeting where absolutely everybody in the community comes to discuss community problems; but in the well organized and larger community, there is need for real and frequent conferences of a comparatively small group concerning fundamental plans - meetings where a long look is taken into the future and possibly where experts or specialists are called in to assist. Conferences will usually be on specific improvements such as roads, health, disposal of sewage, a farmers' exchange, community breeding, etc.

The Community Extension School. In many states 


\section{THE FARMER AND THE NEW DAY}

the agricultural colleges and farm bureaus coöperating hold extension schools lasting perhaps three or four days. These have been warmly supported by the farmers as a rule. There ought to be in each community each year a school in which teaching should be done by specialists - not necessarily all of them college men and women - but real specialists who can really teach the farmers something. But this school should have for its subject matter those fields of thought that have a bearing upon the problems and programs of the community. In other words, the extension school should tie up with the most pressing needs of the community and should throw light upon how the needs can be met.

\section{THE COMMUNITY CENTER}

There has been a good deal of discussion during the past twenty years concerning the establishment of a community center. Very recently the community center movement has swept the country and is being pushed not only in cities but in rural districts. What does all this mean and how important is it? Various plans have been suggested from time to time and each has its advocates.

The Church as a Community Center. For some years there was considerable advocacy of the idea of making the church the rural neighborhood center. It is perfectly practicable to make any one church a center for many community activities. No doubt that is desirable in many cases; but wherever there is more than one church in a community, the plan for making the church a community center is barred from consideration. But suppose there is only one church - then is not the way clear for making that church a true com- 
munity center, the church building a true neighborhood house? Yes; the way is clear, and the plan is worth trying. But after all are the best results to the community likely to accrue from dependence upon a single institution, no matter how strong and active? Is it, moreover, the real function of the church to furnish the complete machinery for all community activities? Is not the task of the church to infuse the spirit and motive into the activities of all individual and collective life rather than to embody the tangible expression of those activities?

The School as a Community Center. How about the school as a community center? In case of the small district school, the limitations of the building are such that its use for general purposes by adults is not practicable. It is too small, the seats are not made for adults. Of course it may serve after a fashion for community gatherings. But if it is to be a community center, it needs additions that make it virtually a neighborhood house. Suppose however we are about to erect a new schoolhouse which is to be the only school building in the community. Suppose this is to be a real country-life school. Why not make the building also a neighborhood house and the real community center? Fine! But the question would arise whether we have built a schoolhouse or a neighborhood house. The surgestion comes at once, why not incorporate the schoolhouse in the neighborhood house? This may often prove wholly practicable and, if practicable, both economical and desirable-economical because it saves one building, desirable because it brings the school life and work into natural harmony with the community activities. The weakness of advocating the school as a community center lies in the fact that this is prac- 


\section{I78 THE FARMER AND THE NEW DAY}

ticable in only a few communities, at least for some time to come, and further in the danger of providing inadequately for activities if the needs of the building for school use are the first consideration.

The Community House. There are places here and there, and probably a good many of them in the aggregate, which have actually established community or neighborhood houses equipped for all community uses, where people may foregather perhaps chiefly for recreation, but also for other purposes. A community house is usually the center of the recreational life of the neighborhood or community, both for old and young.

The Town Hall. The town hall has not much utility outside of New England, but is worth mentioning because in that region it often is by all odds the best natural community center so far as the building is concerned.

\section{ANOTHER VIEW OF THE COMMUNITY CENTER IDEA}

Let us not commit ourselves to the idea that the community will find any one building or institution desirable for all its purposes. In many cases, undoubtedly the consolidated school, for example, is the best place for a community center. But there is something behind the community center notion bigger than any particular building or institution. Instead, we may find that it is not a building we want but a group of buildings, preferably, though not necessarily, grouped in the geographical center of the community, each building embodying some large general interest. Let us illustrate:

I. The Farmers' Exchange. It would be well if each farming community had headquarters for all its 
business interests, where the buying and selling of products could be carried on, and which would also contain a meeting place for the farmers to discuss their business problems. Where the Grange exercises a real leadership in the community, it is quite possible the Grange hall could be used for this purpose; although as a rule the farmers' exchange must be at some center where the farmers' business is actually carried on.

2. The Schoolhouse. The schoolhouse surely ought to be the center, at least, of all the educational and cultural interests of the community. The consolidated school lends itself to this work most admirably and this is one of the main reasons why consolidated schools ought to be advocated. Such a school may house the community library, which unfortunately is poorly developed in most farming communities. The schoolhouse is the natural meeting place for study clubs, for lecture courses, and for the community forums; for extension schools and continuation schools; for museums and educational exhibits. The community should keep itself at school and the school should serve always the educational interests of old as well as young.

3. The Community House. The community also needs a sociable center, that is, a place where there will be no cliques, but where all the people of the community can meet for common recreation and sociable intercourse. The community house is most helpful in developing this side of community life. It is virtually a farmers' clubhouse. If the school does not furnish a playground for youngsters, perhaps such a field could be connected with the community house. At any rate, there should be games, a motion picture equipment, a stage for theatricals and musicals, a piano - frankly, 
we want to develop an amusement hall owned and managed by the community.

4. The Church. The church ought to be the natural and recognized center of the great ideals and the spiritual refreshments of life. It is the supreme place for considering the rightness rather than the expediency of action. A church, of course, must be a friendly place because friendship is the most religious thing in the world. But perhaps it ought to be less of a social club and more of a community school of practical religion than it has ever been before. Certainly teaching and discussion of community affairs and of world-wide affairs from the religious point of view must be a large part of a successful church. The great fundamental purpose of the church as a community affair is to try to lead the people to discover, through conferences and worship and friendly, brotherly discussion, how the teachings of the great religious leaders, but primarily the teachings of Jesus himself can be applied in the daily work and life of the people of the community.

Community Centers rather than a Community Center. Now this program may seem altogether too big for the average rural community, but if we stop to think about it, it is not so serious as it seems. First, a farmers' exchange or coöperative business organization wherever it is established, must have headquarters. Make these headquarters the rallying point of all the business interests of a community and you establish at once an economic center of the community. Every community has a school, perhaps several of them. Simply enlarge the work and functions of the school and build a schoolhouse adrpted to these new functions. The modern consolidated school building actually does this very thing and has just these uses. Not 
many communities have a neighborhood or community house, but every community has at least one church; so that in advocating this sort of program, we are really simply making use of existing buildings and agencies as community centers, except that we set the community house (which, by the way, may be some existing building in the community) as something to strive for.

Let us get firmly fixed the thought that the mere enthusiasm for a community center is not necessarily good in itself. What we want is something that brings the community together, that gives the community interests a hearthstone, as it were, a building which will be the concern and practical expression of community interests. We find at least four main interests in every community.

The community working.

The community learning.

The community playing.

The community worshiping.

It would seem natural and fitting that each one of these interests should have its particular building or center. But if the people of the community think it desirable and experience proves that it is practicable, all of these interests can be brought together in one place. The question whether a community center shall be the schoolhouse or something else or several buildings, is purely a practicable question for each community to settle. But the fundamental principle is that each of these main interests of the community shall have an abiding place, and shall "head up," as it were, in permanent headquarters. 


\section{I82 THE FARMER AND THE NEW DAY}

\section{THE COMMUNITY GOAL}

Doubtless the reader, considering the plan of community organization which has been suggested for the first time, will regard it as altogether too ambitious. But it is intended to serve as something to look forward to in those communities where a simple method of organization is the only one that is practicable for the present. A little study, however, of the plan as suggested will reveal the fact that the details simply illustrate general principles. The great thing is to have a farming community studying itself, planning ahead, acting as a unit.

Each community can tell best how to do this. Each community should have an objective or goal somewhat as follows:

I. Geographically, to map out a natural and convenient area which permits all the people living within its boundaries to get together frequently.

2. Economically, a program of the business of the community which is best adapted to secure the greatest efficiency in the use of the land and in methods.

3. Socially, a group in which the people plan together for self-study, for sociable life, for all forms of improvement.

4. Politically, a group who, while they may not agree on national politics, are after all willing to study and discuss not only the measures that interest them locally, but the significant questions of the day.

5. Spiritually, a community or group feeling and sentiment, cherishing the ambition to have all individuals and agencies seeking their own best interests wholly in relation to the interests of the entire community. 
THE COMMUNITY IDEA IN PRACTICE

The idea of local community organization is not merely a theory. There are many instances running all through our agricultural history of entire communities developing all their work and life as units. In more recent years almost spontaneously there have sprung up community breeding plans, enterprises, cooperative agencies on a community basis, and very recently hundreds of community groups have been organized in many parts of the country. Just at present, the farm bureau movement is urged as a fundamental part of its program.

THE COMMUNITY METHOD OF ORGANIZATION AND WORK

The organization of an old, established community presents much greater difficulties than does a new community where the plan can be formed and the community adapted to it. The possibilities of both these methods may be seen by a comparison of two rather well known examples - Hardwick, Mass., and Durham, Cal.

Hardwick was one of the very early towns to give attention to organization and deserves notice because it has developed the plan further than many. It is an admirable instance of a rural community which has organized on the lines laid down in this book, and an experience of nearly six years has justified the plan; it is worthy of a much longer description than can be spared for its effort in these pages. It is a distinctively rural agricultural town with something over 100 farmers. It has, of course, the advantage of good local leaders.

The local organizations came together for mutual 


\section{THE FARMER AND THE NEW DAY}

help and planning through a community council. A definite long-term plan of development was worked out by the community. A coöperative association was organized among the farmers and has been of great value to the town. The volume of business done by the association increased from a little less than $\$ 10,000$ in 1914 to nearly $\$ 40,000$ in 1917 . An orchard pruning and spraying campaign was undertaken. This reached most of the orchards in the town and the result was a new and lasting interest in fruit growing. The local demonstration farm became the center for poultry breeding stock, and a community breed was adopted. The dairy farmers have been interested in purebred cattle and the number owned in the town has been increased many fold, most farms carrying the same breed. Provision was made for carrying on club work among the boys and girls of the town, and canning clubs, home economics clubs, Boy Scouts and CampFire Girls have been organized. A landscape architect was secured to work out a plan for the development of the common, and this plan is being followed carefully. Various community celebrations have been held and a special community day offered an opportunity for an exhibition of purebred dairy and poultry stock.

Durham, Cal., is a community built from its inception upon a definite plan. Established under California's land settlement act, provision is made by the state for all social and economic development of the community. Soil experts selected the location and determined the most desirable size of holding. Architects prepared the plans and specifications for suitable homes, and the building projects were supervised by the state, relieving the individual settlers of that bur- 
den. Irrigation and drainage systems were established under the supervision of engineers. An agricultural superintendent was provided to whom the settlers bring their farm problems. The lots are sold to settlers on 20 years' time and amortized payments at five per cent. interest on land and improvement. The state also supplements the capital of the settler, when necessary for the purchase of equipment. The state board administering the provisions of the land settlement act selected the settlers with the greatest care, the number of applicants greatly exceeding the number of farms.

Allotments for farm laborers have also been made, suitable houses being planned with enough land for a garden, poultry and cow for each family. A stock breeders' association has been formed and this requires that the colony shall keep but one breed of dairy cattle, one breed of hogs and two breeds of sheep. Only purebred sires are to be used and these must be approved by the association.

A sufficient tract of land has been reserved for a community center for educational and recreational purposes. A movement already on foot looks to the establishment here of a vocational training school in agriculture.

The success of this method of organization seems assured. Within less than a year after the holdings were offered for settlement I oo families were settled on the land and not one had failed to make payments to the state when due.

\section{THE COMMUNITY IDEA AND RURAL AGENCIES}

One of the profoundest results of applying the community idea to local farm areas is the effect upon the local institutions, the school, the church, the Grange, 


\section{I86 THE FARMER AND THE NEW DAY}

even the home. To discuss these important matters thoroughly would require a book by itself; but a few suggestions may be made that indicate the extreme importance of the effort to inspire local institutions to become community building rather than self-serving agencies.

The Rural Home and the Community. At first thought, it may seem as if the home, the most important of our social institutions just because of its private and sacred character, might not fit into the community idea. But the home is the very fundamental of the community spirit. It is the basis for real culture for both children and parents. It may train its members into the coöperative idea and help them acquire the habit of community service. It can coöperate with school, church and playlife. The home maker is not only the mistress of the home, but she participates vitally in community building. Her influence in all community activities is pervasive and all important. Shall the home look outward to the community or only inward to its own limited interests? Shall the home be counted upon to foster the community spirit and practice community service?

The School and the Rural Community. The school in the United States has always been a community affair in a certain sense since it is a public school. It is doubtful, however, if in actual achievement it has measured up to the community idea. The teaching in the school tends to be individual rather than social. It is thought of as fitting each particular child to make his way in the world. A true ideal for the school is that it shall be, as a school, a means of contributing to the highest development and best welfare of the community in which it is located. How can this be done? We 
must develop a real purpose, first of all, to make the school a community building institution. Each school in itself should be a sort of community. The schoolhouse may be the center of many community enterprises and interests. Wherever possible, it will become a community meeting place, a community forum, the entertainment center, but more than all, it is the educational agency of the entire community, not only for the children but for adults as well. We should cease to think of the school as merely a place for training children. In a democracy, the people of the community should always be in the process of being educated. The public school can be almost as useful to adults as to children. In this way, it becomes a great community serving institution.

The Farmer's Association. Some years ago in Massachusetts, the State Grange adopted the slogan that each subordinate Grange should try to be a community building organization. That is, it was not to think of itself merely as seeking the interests of its members alonc, but was to utilize the power of associated effort that arises through the Grange for the benefit of the entire community. This sound principle applies to all voluntary associations. It is legitimate for groups of people to band themselves together to advance their interests, but more and more the obligation comes to them to use these agencies for the benefit of all within their reach.

A Community Serving Church. The country church should point the way toward the application of a religious motive, both to character building and to community building. It should explain how the Kingdom of God may come within and without. It should make clear the principle that the Kingdom never will come 
to the individual except through his work and his relations. It can come only in communities. Community building then becomes the prime task of the country church; through preaching and worship; through the presence of a resident pastor who regards himself as a community builder; the developing of many community activities; the practice as well as the preaching of true democracy, the church will become a vital factor in the community.

Local Rural Government. It is needless to say that local government should be honest; it must also be efficient. In dealing with public health, protection of life and property, community conveniences and all educational work, the local government already finds its field. But is it not possible to enlarge the function of the local government? As the country community comes to need water, sewerage systems and so on, shall not public utilities be under public control in the country as well as in the city? Why should not the county, for example, own and control a slaughter house, a cold storage, a system of elevators? In many counties the town or township is required to appropriate public money for the agricultural interests of the region instead of relying wholly upon the state or the nation or even the county as a whole.

\section{WHY SO MUCH EMPIIASIS UPON TIIE ORGANIZATION} OF THE LOCAL COMMUNITY?

In this book, two chapters are devoted to this one idea. Why so much talk about it? L.et us summarize.

I. To secure full efficiency in rural affairs, it is necessary to have relatively small groups or units. There is no business, no government, no army, no organized activities of any kind but finds this essential. It has 
already been stated but cannot too often be repeated that even in agriculture the necessity of this relatively small grouping has been proved over and over again. It is the local church, the local school, the local Grange or Union or farmers' club that gets results. It is impossible for a single farmer to coöperate with seven million other farmers. If he coöperates at all, he must coöperate with at most a few hundred, in nearly all of the effective acts of his life. The nation, the state, even the county, are too big for effective coopperation. So somewhere, in some way, we must bring together a few hundred farmers, and from these form what we are calling the local farming community. Whether there shall be Ioo farmers or I, 000 farmers depends upon conditions. But there must be enough of them so that they can work together through institutions which they can maintain effectively, and not so many of them that they cannot work togrether as one man.

2. The local community fully organized deals with all parts of the farm problem. Consequently, it is "agriculture in the small." The interests of the local community are identical with the interests of all the farmers of the nation or of the world, but on a scale so small that they can be dealt with.

3. Acquaintance, friendship, coöperation, frequent meetings are essential if people are to work together for any length of time in any efficient way. Now these things are possible only in relatively small groups, and when the small group is acquainted, friendly, coöperative, meeting together, you have a community.

4. If efficiency in agriculture and country life cannot be realized in these ways, it cannot be realized at all. That is to say, if the great majority of perhaps 50,000 farming groups or local communities are not pro- 


\section{I9O THE FARMER AND THE NEW DAY}

ducing effectively, or managing their farms well, or making a profit, then American agriculture is not successful. The mere fact that certain farmers here and there accomplish these things does not make a prosperous agriculture.

5. And finally, if we are to secure a complete democracy among farmers, political, industrial and social, we shall get it only as we make it and keep it in the local community. If the local communities are not democratic, the farmers as a whole will not be democratic.

And so we emphasize the organizing these thousands of real farm communities as perhaps the crowning need of the farmer in the New Day. 


\section{CHAPTER XI}

\section{THE STATESMANSHIP OF RURAL AFFAIRS}

\section{SOME WAR-TIME LESSONS FOR AMERICA}

AMERICA's participation in the war has revealed certain weaknesses in the organization of American agriculture. No national agricultural program existed at the time war was declared, and has been but partially developed during the war. We have stood in need of a mobilization of agriculture somewhat akin to the mobilization of an army. We have needed an agricultural general staff. Nor has there been a real coördination of the interests of producers and consumers in the big problem of food supply. The farmers themselves have responded magnificently to the appeals to grow more food, and the machinery of the Department of Agriculture, of the colleges of agriculture, and of the farm bureaus has been unceasingly devoted to helping the farmers. There has been criticism of the federal Food Administration, but also a growing belief that it has been governed by wise statesmanship, a rare foresight, and motived by high aims. But we have not yet gained out of the war that close, definite, intelligent, well-understood coördination in the whole problem of food supply that we ought to have. We find that we have no agricultural policy maker. Congressmen have repeatedly said, "How do we know who expresses the real agricultural thought and interest?" The farmer's vacant chair in national and in- 


\section{THE FARMER AND THE NEW DAY}

ternational councils has been all too obvious. Much new social machinery has been built and utilized for emergency agricultural production and distribution and for propaganda in rural districts. Some of it might well be saved for future use. There has been as yet no authoritative coöperation with European agricultural leaders on the larger policies, nor any representative body studying agricultural reconstruction at home.

\section{THE GOVERNMENT AND RLRAL PROGRESS}

The province of government in the New Day will soon be a burning issue in America. Shall or shall not the government munage the railways, the telegraph lines, grain elevators, packing houses? Shall the government fix prices, or assist in land settlement, or provide agricultural credit? Shall the government do more or do less than it is now doing for agriculture? While these questions are supremely important to the farmer in this new time, our discussion of them herein must be exceedingly brief and in the form of a few mere suggestions.

Legislation and the Farmer. As a rule, legislation is haphazard. It often results from the individual notions of some legislator or possibly grows out of the prejudices of a group of legislators. More often it is just sheer compromise between the radicals and the conservatives. While a compromise is a very practical sort of affair, it is not always wise. Perhaps some of the inequities and inadequacies of legislation in rural affairs could be remedied through the existence of a strong national association for agricultural legislation. We already have the beginnings of such an agency. Properly developed, this will be composed of both spe- 
cial students of economic and political affairs as related to rural matters and able, broad-minded, representative farmers. Such an association is intended not so much for propaganda purposes as for sober, hard thinking about fundamentals. Its written expressions ought to be worth while, possibly even authoritative. They will not be infallible but they should secure the attention of the great farmers' organizations as well as legislatures and Congress. Another helpful agency would be national and state councils of agriculture and country life, which would gather around a conference board the representative leaders of all the different institutions interested in rural affairs in order to reach some agreement as to what is wise and best. No doubt the growth of a powerful farmers' organization which definitely represents the voting farmers would have the backing that is absolutely necessary in political propaganda. But this powerful farmers' organization should not make its demands simply because it is powerful, but because its demands are just and wise. There is need that this entire field of agricultural legislation should receive the best thought of our best minds.

$A$ Governmental Rural Policy. In an earlier part of this book, it was stated that a policy may be simply that which actually happens through a series of years, but that a policy for the New Day, a real policy, implies adequate knowledge, definite plans, correlation of effort. So in our governmental affairs, whatever is done or advocated by departments, boards or bureaus, should be the result of a well-founded and wellrounded policy. Probably there is in these agencies no lack of definite knowledge, and it should be easy for them to make plans. But it is more difficult to secure their coöperation. Within the state, for exam- 


\section{I94 THE FARMER AND THE NEW DAY}

ple, how may we adjust the administrative functions of a department of agriculture and the educational functions of a college of agriculture? We find in Washington half a dozen or more bureaus or boards dealing with matters of agricultural education. If these cannot be consolidated, at least they ought to be forced to coöperate intimately and freely and unreservedly. Perhaps an agricultural development committee in each state and in Washington might be a means of grace in this connection. The British Agricultural Development Committee is virtually an advisory committee to Parliament. It has no direct authority, but its recommendations as to appropriations and as to the work of the different governmental agencies, both national and local, carry far in Parliament. Some such group authorized by law, and composed of representatives of the public agencies involved, with additional members appointed by the President and in the state by governors, might be able to secure the necessary coöperation of governmental agencies. The war has immensely increased here in America the ambitions and activities of various governmental agencies. It is not too strong a statement to say that we are on the verge of chaos with reference to the inter-relationships of public boards, departments and bureaus. It is a serious situation and there is only one way out. There must be coöperation, if not voluntary, then compulsory.

Information. Whatever our conclusions as to the place of the government dealing with agricultural matters, there is clearly one task that it can perform better than any other agency and which is evidently its duty. That is the task of discovering and disseminating information. This function embraces the necessity for accurate investigations, for wise and clear interpreta- 
tion of these investigations, for well planned and numerous demonstrations of the applicability of the principles worked out as the result of investigation, and for widespread publicity that will reach the masses of farmers with understandable expert advice. Government, both state and national, should gather and distribute the fullest possible information on all of the different aspects of the rural problem. Its duty does not stop with information about production, but includes the field of distribution of farm products and the welfare or country life phase of the farmers' interests. This information should not only be made available to all the farmers, but they must be all but compelled to listen if they are unresponsive.

The government should keep a large staff of experts in all foreign countries gleaning every shred of information possible about food needs, agricultural methods, agricultural legislation, rural organization, country life endeavor. We are sometimes led to think by the vastly enlarging appropriations granted to our federal Department of Agriculture and its manifold and increasing activities, that we are taking care of this phase of governmental activity in thorough fashion. As a matter of fact, the present agencies are inadequate. For one thing, they are provincial, dealing with too narrow areas of interest; they should scour the world. They are too narrow in their scope; only within a few years have we even touched the field of distribution, and country life interests have received slight consideration. Moreover, in spite of our farm bureaus and extension services, we still fail to reach a large majority of the working farmers with all the information that they need regarding the world's need for food and the world's supply of food. We have made a good deal 


\section{I96 THE FARMER AND THE NEW DAY}

of progress, especially since the war opened and particularly in the matter of market information, the range of prices, etc. But we need at once closer coöperation between the federal Bureau of Markets, the research and extension divisions of the agricultural colleges in the field of marketing, and the state market bureaus, which are administrative and not educational. W We must know what is happening in the agricultural world, and how it affects America.

Relationships. The federal government is the only agency that can properly determine and adjust interstate and international relationships in rural affairs. We must rely upon it to find the proper place for agriculture in our foreign trade. In coöperation with the great associations of producers, it must work out such zones of production as may be feasible.

Coöperation with Voluntary Agencies. This is one of the great needs of the New Day. We have a right to expect that the government, through the Department of Agriculture, will take the initiative in getting into close touch with the various agricultural agencies and associations. Unfortunately, these agencies do not always respond in the spirit of coöperation. Sometimes there may be fear on the part of the government officials that if they call into conference representatives of farmers, demands will be made which will limit the freedom of action of the officials. But it should not be difficult to avoid this, if both the government officials and the representatives of the farmers once become impressed with the need of common counsel and planning.

Government Orunership or Control. The farmers were the originators of the demand for governmental regulation of railways, and we have long since passed the stage of irresponsible railroad management. Gov- 
ernment ownership of railways is clearly to be one of the great political questions of the period after the war. The issues ought to be clarified now so far as the farmers are concerned. The question is not wholly that of abolishing the evils of exploitation through private management, nor the advantages of unification that result from government control. The main issues in the immediate relation between railways and agriculture is largely one of adjusting rates on a basis that will give the largest measure of justice to competing areas or regions of production. This is a most complex and difficult task. It affects consumers as well as growers. For example, the splendid railway refrigerator system, the fast freights and so on, have brought the perishable fruits and vegetables of the West to the eastern markets. This has been a great advantage to the western producers and possibly to the eastern consumers, but it has undermined eastern agriculture of a certain type. This instance is typical of an innumerable list of cases where transportation, like many other improvements, disturbs production. These changes are inevitable. But if they reduce the profits of large numbers of farmers, protests will be strong and frequent, particularly if government is responsible for the conditions to which the injured farmers object.

It is improbable that in the near future there will be in America a serious demand for the nationalization of the agricultural land. But there are many evidences that we are already on the verge of a growing demand that the government shall take charge of the task of providing land for tenants and young farmers on better terms than they can secure at present. The increasing extent to which farm lands are passing into the hands of capitalists, either the capitalist farmer or the cap- 


\section{I98 THE FARMER AND THE NEW DAY}

italist banker or merchant, is creating a strong pressure for governmental action of some sort.

Theoretically, the ideal marketing machinery for farm products would consist of a thoroughly organized group of agricultural producers, dealing with cqually well-organized groups or communities of consumers, with only such intermediaries, and these also presumably well organized, as are absolutely necessary to the most effective handling of the product from grower to consumer. Through storages owned in part by producer and in part by consumers, and with large collection units or centers managed by producers' associations, and large distributing centers or units managed by consumers' agencies, a large part of the present machinery of the middlemen would be displaced. Public markets would be a factor in the plan. Then with the government owning or controlling the means of transportation, we would have a thoroughly democratic and effective scheme of distribution of food products.

Practically we are a long distance from the realization of such a well-balanced scheme, but government may at least encourage and aid the organization of both producers and consumers, and through its police power abolish the more flagrant abuses that arise in the present distributing process. Much will be gained by a more complete system of information, gathered and disseminated by government, relative to food needs, food supplies, food prices, food movements. Fortunately, a good beginning has been made in this field. Publicly owned elevators, abattoirs, storages and warehouses we may be obliged to have if private interests do not bend to reasonable demands from the farmers for fair dealing.

As a general principle, we should accept the idea that 
the best service of the government to the farmer is to help him to help himself, or rather to help the farmers to help themselves through coöperative methods; and to refrain from all activities that can be done well by individuals or by voluntary organizations. Government regulation has become an absolute necessity; there is no question about that principle. With respect to government management or even government ownership, we ought to be in the mood to have it wherever it has become clear that voluntary organizations of producers and consumers on the one hand, and state and federal regulatory laws on the other hand, are still ineffective to get substantial justice for the great masses of producers and consumers.

Federal Appropriations. The federal government has been quite generous to agriculture. But there will be new and extensive calls for federal money for many purposes connected with agricultural improvement. There may be, however, a growing resentment at too detailed control of such funds from the federal treasury as are appropriated and used in the states by federal authority. There is a widespread feeling that the federal government should appropriate money for certain state purposes, and let the states handle it as they like. The tendency of Congress is to insist that the federal appropriation shall be supplemented by state and local appropriations, the work to be planned jointly and executed locally, but with close supervision by the federal government, and with the latter holding veto power over expenditures. There are those, too, who are strongly opposed to federal appropriations for agricultural purposes on the ground that each state knows best its own needs, and has an obligation to take care of its own problems; and also because of an earnest con- 
viction against the policy of centralized control of local enterprises by the federal government.

On the whole, it is advantageous to have federal appropriations for the larger interests of agriculture, provided these appropriations are supplemented by state appropriations. A federal law of this character at once tends to nationalize and broaden all good movements. Agriculture and country life are national, not state, concerns; it does make a difference to the whole country if one single state has neglected, for example, the development of an adequate system of agricultural educatio 1. A measure of control should follow every public appropriation; consequently, a degree of federal control should follow all federal appropriations. The real difficulty comes in deciding upon the extent of control. The federal government should determine through the law itself what are the main large ends or objects to be pursued with the money thus appropriated, and should require of the states plans or projects which appear to be promising and effective in reaching these ends. There should be detailed accounting for the use of the money, and a day of judgment at least once a year in which the projects are checl:ed up to determine whether the money has been used for the right purposes and in a reasonably effective way. The continuance of federal appropriations should depend upon the proper use of federal money. Beyond this federal control should not go. The moment it attempts to decide details, to determine personnel, to pass judgment on local needs and particularly when it attempts to secure uniformity of method and standardization of projects throughout the country, it is in danger of becoming bureaucratic, ineffective, and wasteful. 
SOME LIMITATIONS TO GOVERNMENTAL EFFICIENCY

Laws in themselves carry limitations. It is rare that a law meets all situations adequately. Moreover, under the law there arises an increasing necessity for administrative rule which, while only purporting to be an interpretation of the law, has all the force of law. The great difficulty with these laws and rules is that they are so iron clad; if their wisdom is questioned, there is slight redress. What is best and wisest and most effective may be buried in the reiterated answer of the official, "This is the law." One of the penalties we pay for the reign of law, which of course is the bedrock of civilization, is the temptation on the part of administrators of the law to become tithers of mint and anise and cummin.

In all government affairs, there is a growing necessity for order and system; so we develop formal written projects and memoranda. They are valuable, probably indispensable. But their use tends to the emphasis upon a paper plan rather than upon the significance of the results to be achieved by the plan. The consideration of these documents consumes time and energy and often causes serious delays. As these things increase, greater becomes the lack of personal responsibility and personal judgment, and more and more decisions are made on the basis of precedent and rule and form rather than on actual needs. The administration becomes rigid rather than plastic and practical. Government officials find themselves under the almost irresistible necessity of forming judgments in the office rather than in the field. In a great organization, it is not easy to secure the best man for the most important administrative positions and it is difficult to get rid of incom- 
petents. Officials tend to become conservative, cautious rather than original and aggressive. There seems to be a tendency on the part of government officials to resent suggestions from outside. To be sure, they are the targets for all sorts of foolish suggestions and unfortunately, almost unconsciously perhaps, they form the attitude of thinking of the outsider who makes suggestions as an interloper. In the same way, governmental bureaus more and more seem to desire to do their work without reference to other agencies. Some of the younger men engaged in our great system of agricultural education hardly know that the great farmers' organizations exist and often fail to understand the fundamental need of preserving the initiative and the cooperative power of the farmers themselves. The general policy of the government bureau is more or less subject to the limitations of the chief officials who change from time to time; generally speaking the responsible administrator tends to be cautious rather than a leader.

THE DEPARTMENT OF AGRICULTURE AND THE AGRICULTURAL PROGRAM

A recent letter from one of the ablest of our agricultural leaders stated a strong conviction that no question should be raised concerning the right and duty of the United States Department of Agriculture to outline an agricultural policy and to make our agricultural program. There is no doubt but the farmers themselves have always looked to the department for leadership. The creation of the department as a cabinet position was due very largely to the efforts of the farmers' organizations, Jed by the Grange. In the earlier days, it was expected that the Secretary would be a farmer. 
The farmers wished to see themselves represented at the nation's council-table by one of their own kind. They wished to feel that they had a part in shaping policies. They delighted in the sense of partnership with the government. They expected that the Secretary of Agriculture would in a measure become the farmers' spokesman to the President, to Congress, to the nation and to the world. There are many students of rural affairs who believe that the department should be the unquestioned agency to organize policies, map out programs, lead the force of agricultural improvement. Among the officials of the department, there is probably very strong conviction concerning the primacy of the department as leader. But there are considerations of caution.

There are the administrative limitations already mentioned; - those that belong to government as such; they are a menace to originality, reform, agitation, even to statesmanship. In spite of all the good intentions of public officials there will always be a tendency to get away from the working farmer.

There are functional limitations - some things that we do not want government to do. American country life, for example, can never be all it ought to be apart from a virile religious life. Obviously the government cannot manage the church. Government cannot buy the farmers' supplies for him nor sell his crops for him; no one expects the farmer to surrender his business initiative to the government.

The farmer can be truly represented only by the farmer. The public official may be a wise guide and counselor, and if so his word ought to be listened to and heeded; but no public official, not even an agricultural college president, has the power to speak in the same 


\section{THE FARMER AND THE NEW DAY}

fashion about the needs and wants and demands of the farmers as has the working farmer or the official designated by the farmers' organization to speak for it. The official may appreciate the farmers' attitude, and he should have the courage to tell the farmers at times that they are wrong in their attitudes. But no government department can exercise complete leadership in agriculture for the reason that they are not of and by the farmers.

Political action lies outside the jurisdiction of the Department of Agriculture and of the colleges of agriculture; yet there can be no adequate agricultural leadership that does not have in it the possibilities and the power of political action. If we are to have a democracy, the agricultural part of it must not be voiceless or dependent upon any government agency for expression of its political power. At times it may be necessary for the farmers to exercise their political power in opposition to the government agency.

Although urging the enlargement of the activities of the government as a source of information to farmers, it is realized that over-much dependence upon the government may check individual and community initiative, and prevent what after all is the great aim in governmental activity, to help the individual and his local group to help themselves. European states with the most efficient agriculture do not depend upon the government nearly so much as they do upon voluntary organization. The government is the only agency to develop systems of agricultural education and regulation. Governmental authority is indispensable. But it will be most unfortunate if the American farmers fail to organize themselves in the community and in the state and in the nation; it will be deplorable if they become 
completely dependent upon the United States Department of Agriculture for initiative and leadership and statesmanship.

Is not this unduly minimizing the work of the department? No; it is merely indicating its limitations as the one source of agricultural leadership. The department in the New Day should:

Keep abreast, even in advance, of the most progressive thought of the world concerning absolutely all aspects of the problem of agriculture and country life and how the problem may be met.

Frame a clear-cut, statesmanlike policy and a very definite progressive program for its own activities.

Assist in securing complete coördination with other publicly supported agencies, national, state, and local.

Maintain the fullest and freest coöperative relations with voluntary associations of farmers, especially with the great national organizations of agriculture and country life.

\section{THE LEADERSHIP OF ORGANIZED FARMERS}

It is difficult to discuss this question of agricultural leadership without seeming to criticize governmental agencies and to show lack of faith in the wisdom of organized agriculture, and it is hoped that nothing that has thus far been said will be construed as criticism. It is simply a point of view based on the earnest conviction that the farmers of a free country must not become dependent upon government. So we look for the farmers of the New Day to get together, to unify and organize interests, to present a solid front not in antagonism to the government agencies, but in coöperation with them. It is only in this way that it is at all possible to have a genuine statesmanship of rural affairs. 


\section{THE FARMER AND THE NEW DAY}

On what plan can farmers develop that full measure of organized effort that will give them power to speak and act together? The following scheme is at least suggestive.

I. Develop as rapidly as possible the organization of producing groups such as the cotton men, the livestock men, the dairymen. These should interest themselves to an extent in increased production, but to a much greater extent in efficient methods of buying their supplies and selling their products, and in legislation affecting their business.

2. Maintain the great farmers' organizations, such as the Grange and the Farmers' Union, with rather large, general objectives and with a very broad policy and program.

3. Endeavor to secure an overhead but perhaps loosely associated league of all organizations of farmers, possibly much like the present National Board of Farmers' Organizations, which will draw toggether the various organized activities of farmers for conference and counsel.

4. It is possible that such a league of farmers' organizations may be sufficiently aggressive for all legitimate political purposes that the farmers may care to press. If it is not, however, there will be a place from time to time for definite political movements on the part of farmers.

5. Make a plan for securing the clear-cut coöperation with organized farmers of all the publicly supported agencies for agricultural improvement, particularly those of an educational nature, but including also the administrative or regulatory bureaus and departments.

6. There should be a national country life committee 
which should seek to bring to a common platform all the activities of the associated efforts that are already at work or that may develop on behalf of rural education, the rural home, adequate recreation, health and sanitation, country planning, and morals and religion.

7. In some way the interests of the city, not only of consumers but also of urban agricultural business interests, should be recognized in order that they may be brought into intimate touch with the farmers and the agricultural agencies. We cannot make progress in the New Day unless the agricultural interests in food production and distribution are tied up with the interests which the rest of the world have in the agricultural industry.

8. Establish a National Council of Agriculture and Country Life that will be a conferring and deliberating body, large enough to be thoroughly representative of all public as well as voluntary agencies. It should be small enough for deliberate counsel. The National Council of Agriculture and Country Life would not commit any of its members to policies subversive of their interests as they see them. It would simply be a central body which, by its careful deliberations, by its wide representation, and by the breadth and scope of its purposes, would be considered by the farmers themselves, by Congress, and by the world at large, as the responsible spokesman for the best thought and purpose in American agriculture and country life.

\section{THE FARM PRESS}

The agricultural press is an exceedingly important factor in rural advancement. As a rule, it deals thoroughly and adequately with problems of production. Certain agricultural papers have for many years cov- 


\section{THE FARMER AND THE NEW DAY}

ered in a clear-cut way the business requirements of farmers. Some, however, have failed to appreciate the coöperative movement or have overdone the attitude of bitterness toward the middleman. Others have been inclined to cater to the farmer's prejudices and to hammer incessantly at the city man and his interests and his theories. Probably, as a class, the agricultural papers have neglected the country life aspects of the rural problem. Various organizations of farmers have their organs which deal much more with the machinery of the organization than with broad policies. In some respects the agricultural press is the most important single agency in developing rural public opinion, as it is the most widely read of all publications relating to agriculture. It arrives in the farm home regularly and frequently. It assumes to be the spokesman of the farmer, and usually it meets him on his own ground.

Our agricultural editors are among the clearest headed leaders in the whole agricultural field. If one outside of the fold might offer advice to the agricultural press, it would be the importance of seeing the light of the New Day and interpreting fundamental democracy to American farmers.

\section{THE STATESMANSHIP OF RURAL AFFAIRS}

The great war is coming to its close as these words are being written. The world has been made safe for democracy. The war is over, but the great struggle of the New Day has but just begrun. Democracy must be made safe for the world.

If the development of real and permanent democracy becomes the main peace task of the nations of the world, it will be found that it is a task affecting hosts of rural people. It is true that in highly industrial coun- 
tries, like Belgium, England, France, or Germany, the laboring man, the wage earner, will be the spokesman for social reconstruction. Labor has already made its demand that it shall be represented at the peace table. Taking the world around, however, labor as compared with agriculture is a minority party. It has everywhere a big stake in democracy, but so has agriculture. Nine-tenths of the people of Russia are rural. Poland, the Balkans, the larger part of Austria, Asia Minor are either all distinctively or strongly rural. If the democratic movement spreads to India or China, it will have to deal to a very large extent with rural people. Indeed, there are but few really urban nations. Labor is rightfully insistent upon a fuller measure of democracy, and it is more vocal than agriculture, perhaps because it feels more keenly its disability. If the laborer is out of work he soon approaches the dead line of starvation. The farmer may be economically oppressed and yet manage to get bread for himself and his family. But labor is heard chiefly because it is well organized and groups itself in the great centers of population where it has access to public opinion. The farmers are scattered and unorganized and have few organs of public opinion. The great populations of the world can become democratic only as their agriculture is organized and their farm population is intelligent and coöperative.

Agriculture as a world issue will be forced upon us by the demand for food, even if the demand for democracy should fail as a rallying cry. Both sides in the world war were compelled to unify the problem of their food supply. The moment the armistice was declared, an effort was made to treat the problem of supplying food to all the nations that have been at war as one 
large unified task. There is no other possible way of handling the matter, at least until each country has had a chance to get back to something like normal conditions in agricultural production. But why should not this unifying of the world's food supply be a permanent affair? In truth, it is not any longer merely national. There has been much discussion about nations becoming self-sufficing as to food. If we are still to live in preparation for possible future wars, it is vital for national safety that each country should grow as much as it can of its own soil products. But if the world's need is to be met by a world statesmanship, agriculture must be the subject of the wisest planning and the most thorough organization. The farmer cannot be omitted in the evolution of the statesmanship demanded for the New Day. 


\section{CHAPTER XII}

\section{THE FARMER AND THE NEW DEMOCRACY}

WHY do we hear so much these days about democracy? Europe perhaps needs democracy, but why discuss it for America? It is easy to sense the contrast between autocratic Germany and free America. It is clear that when Russia overthrew the reign of the Czar she desired democracy; and it is equally clear that what she really obtained at first was not democracy at all, but merely a different kind of autocracy. Some of us may have read the declaration of the British Labor Party, which calls for a " complete reconstruction of society," and perhaps we observed to ourselves that for England with its House of Lords and its king and its nobility, such a necessity may exist; but as for America we now have democracy and no reconstruction is needed.

Democracy is the outstanding, distinctive glory of our great country. Her mission has been to show the world how to develop a nation at once populous, busy, efficient, free. But this is not the whole story. Most Americans think of democracy as a form of government in which the people rule through their right to vote. Democracy is something far more than popular election of representatives or even of popular vote on laws and constitutions. We may easily mistake the form of democratic government for its reality. Have we never protested against the rule of "bosses" and of "rings" and of "the interests"? Are we satisfied that even in government we have actually realized the full fact of 
a true democracy? But we have made an even more serious blunder. We have assumed that the democratic mode of government makes us sure of the democratic mode of working and of living together. Perhaps we have not even thought of democracy as having any connection with business or industry, or with what we call our social relations. But if we do think about this aspect of democracy, do we not realize at once that the best use of a democratic government is to ensure us real freedom in our work and life? Are we satisfied that even in America the conditions under which the majority of men work are entirely fair? We have seen the rise of labor organizations, the enactment of legislation to restrain monopolies and to regulate huge business enterprises. We witnessed the urge of the Progressive party for "the square deal." Do we not realize that all these things were simply phases of the great struggle for more democracy in all aspects of our national affairs?

We cannot fully appreciate the demand for more democracy, here as well as in other countries, which the New Day will surely bring to us, unless we dwell thoughtfully upon the principles that underlie a true democracy. Let us see what they mean for the farmer. There are perhaps four great ideas that serve as the underpinning of a true democracy:

(I) Individual freedom,

(2) Equality of opportunity,

(3) Responsible participation in affairs, and

(4) Coöperation for the common good.

\section{INDIVIDUAL FREEDOM}

What a world of history has been made in the effort of mankind to achieve freedom - the liberty of indi- 
viduals to act, to think, to believe, to worship, to govern, each according to the dictates of his own conscience, will or interest! Men may follow a long, a torturous, a steep and even a bloody road to freedom, but freedom they will have. The democratic instinct will push its way to the light. But men want the reality not merely the forms of freedom. They must be free to work where they will, free to move out of one "class" into another, free to initiate enterprise, free to go and to come. Freedom is impossible however unless all people everywhere realize and acknowledge the dignity of manhood. A man's a man. The man himself must appreciate this fact. He must seek freedom from ignorance, from prejudice, from vicious habits. He must desire earnestly the best gifts. If he wants others to regard him as a man he must seek to be a man. He must be as ambitious for himself as others are for him. He must not only have the chance to grow into the stature of full manhood, he must want to do it. Real democracy means not merely freedom of the individual from slavery to other individuals, but from slavery to his own worse self.

Is the American farmer free? Undoubtedly he is more free than the farmer of any other country, and probably fully as free as the member of any other great group or class of citizens in America. The farmer's independence has been his pride and has often made him the envy of others. He has stood upon his own feet on his own land, worked in his own way, moved about as he desired. He has managed his own business, bought his supplies and sold his products, made his own bargains. His sons and his daughters have stayed on the farm or have gone into other callings as they chose. 


\section{I 4 THE FARMER AND THE NEW DAY}

Nevertheless, there has been creeping into our farm life a certain dim, intangible limitation to the farmer's freedom, one that the farmer, while often conscious of it, does not always appreciate as a failure of democracy. During the past few decades, certain bonds have been tightening around him. The free land is exhausted; it is increasingly more difficult for the man without capital to procure land for farming. Many of the limitations of the farmer described in an earlier chapter are hedging him about and limiting his freedom.

\section{EQUALITY OF OPPORTUNITY}

This is closely akin to freedom. Freedom implies liberty to act, think, speak freely. Equality of opportunity means that each man has an equal chance with every other man to grow, to make the most of himself. Men are not equal in capacity and no democracy can make them so. But what democracy asks is that each man may have as good a chance as every other man to develop whatever capacity he may have. With the growth of cities, the farmer has probably been slowly but rather surely losing ground with respect to some of his opportunities as compared with those that he would find if he became a city dweller. He has an increasing lack of opportunity to share in some of the things that are best developed where many people are concerned, and where ample money resources are available. On the more superficial side of life, in amusements, conveniences, comforts, the city has rather outstripped the country. Lectures, concerts, operas, theaters, electric lights, rapid transit - these come to the city dweller first and sometimes exclusively. To many farming areas these things are fully available, but in vast regions 
the poverty of such resources is characteristic. This would not be so serious if there were not increasing limitations of a more fundamental sort. On the whole the country child does not have as good a chance for a thorough schooling as the city child. The country church is not, as a rule, exercising as much leadership in constructive thinking about the application of Christian principles to human problems as the city church. Books and solid periodicals are found everywhere in the country, but it is a question whether, for example, there are to-day among farmers as many real students of democratic policies as there are among working men. The isolation of the farmer has helped him to a real independence or freedom, but it tends also gradually to lessen his chances for an equal race with his fellows in other occupations.

RESPONSIBLE PARTICIPATION IN AFFAIRS

We say that in a democracy the people rule. We mean that each citizen has his chance to express his views about how all the people shall act. He participates in government because the whole thing eventually comes back to him for approval or disapproval. Now the oncoming fight for more democracy is based on the idea that the people shall manage their work as well as their politics. We were so proud of our freedom which allowed an individual to manage his own business, that when big business grew up we were inclined to forget that the men who furnish labor as well as the men who furnish capital or those who supply executive ability, should have a part in the management of the entire business. We are now asking ourselves whether this scheme is fair. Does the workman really get his 


\section{I6 THE FARMER AND THE NEW DAY}

share in the gains of industry? Does he have a fair chance to decide upon the conditions under which he works?

It is this test of a democracy that is the most serious when applied to American agriculture. The farmer still manages his farm, subject of course to the inconsistencies of Mother Nature, but it is very doubtful if he manages his business. It takes two to make a bargain; yet the individual farmer participates too slightly in pricemaking, either when he sells or when he buys. "He takes what he can get and he pays what he must" is the crude but fairly accurate way of putting it. Nor does he as yet have free access to the great reservoirs of capital and of labor, nor to proper facilities for protection and insurance, that are available to other men who need to use these factors. He is gradually losing the ownership of his land, the most important thing of all. Farmers have an enormous influence as a group of voters at the polls but not very much in constructive politics. They do not assist as much in planning the big movements and in giving direction to the big forces that affect their industry, as is the case with other large groups.

\section{COÖPERATION FOR THE COMMON GOOD}

Our older American democracy staked its success on the freedom of the individual. The newer democracy puts its main stress upon the coöperation of all individuals for the common good. "No man liveth unto himself "was always good morals; in our time it is good citizenship, good government and good business. Complete personal independence is no longer possible, if ever it was. The world's work is done by groups, large and small, more or less compact and well organ- 
ized. The lone man cannot be really free.

True freedom implies working with one's fellows. Both selfinterest and public interest demand coöperation. The individual becomes responsible to all the rest to an extent that makes his attitude toward them the real test of morals. If he works for the common good he is a good man; if he works against it he is a bad man. In the same way all of us must assume a new responsibility for each individual's well-being.

Perhaps some one will discover a better word than "efficiency" to describe the idea that is now conveyed by that word; but we cannot dispense with the idea. Democracy must be truly efficient if it is to be permanent. Now the key to efficiency is organization - that process by which each person does in the best way what he can best do to help carry out some common plan. But organization usually means a planning and directing mind. There must be a leader, usually a "boss." Democracies realize this and so they choose their "boss." This man is cheerfuly obeyed so long as he himself is efficient and fair; when he is not, he is displaced. An autocracy gives the participants in any given piece of work no chance either to choose or to recall the leader or commander. If democracy so wills, it can be more truly and permanently efficient than an autocracy, because it can substitute free, interested, intelligent, coöperating groups for coerced underlings. These truths apply to industry as well as to government. Here lies one of democracy's great tasks when the war is over - to unite freedom with efficiency, to make coöperating groups, under expert leadership, take the place, the world over and in all departments of human work and life, of compulsory terms of labor and of autocratic methods of organizations. 


\section{I 8 THE FARMER AND THE NEW DAY}

A democracy, therefore, must be fraternal. The highest ideal of a democracy is a real brotherhood. If the spirit of brotherhood be not present in full measure, there can be no democracy. In fact true democracy is spirit rather than form. If you cannot feel right toward your fellows, feel the dignity and worth of each man, feel glad when he succeeds and sorry when he fails, feel angry when injustice prevails and be courageous to insist on the square deal for every man, feel anxious that every man have his chance as well as that you have yours - if you have not this attitude you are by that much short of being a true democrat.

The American farmer is a friendly man. It is doubtful if anywhere in the world there can be found so large a class of people who feel more completely and keenly this fundamental spirit of democracy. But the farmer has been slow to learn the lessons of coöperation. He is still an individualist. Probably only necessity will drive him to coöperation. But the New Day is itself a necessity. The farmers will fail grievously to meet their obligations to the world need if they decline to organize thoroughly for the sake of efficiency and in order the better to fulfill their special responsibilities. It is at this point that democracy calls to the farmer for help.

\section{THE RURAL CONTRIBUTION TO DEMOCRACY}

It would be a great misfortune if, in this supreme crisis of world history, the leaders who seck to rebuild human society everywhere on a democratic basis should fail to include the land tillers in their plan, or if the farmers themselves should fail to rise to the new demands upon their intelligence, their power to coöperate, their loyalty to the best in citizenship. The fact of 
mere numbers is itself important. The farmer vote wherever universal suffrage prevails holds the balance of power or is overwhelmingly the majority vote. The business of farming is vital and primary. The farmers have an innate love of fair play. It is certainly true of the American farmer that he is a thoughtful citizen. He has time to think and he does think. There is a certain poise or balance among farmers, amounting often to undue conservatism, that can assist mightily in an evolutionary rather than a revolutionary progress. Let it be said too that any efforts to prevent democracy from having its way in the new time must not be scornful of the farmer's influence; for once he has broken the moorings of conservatism he becomes a radical of the radicals. The very insistence of the farmer upon the freedom of the individual is good doctrine in a time of organized effort. For let the rural emphasis upon individualism be broadened a bit until it becomes merely insistence upon individuality and we will have almost the ideal attitude. Individualism tends unquestionably to be selfish. Individuality just as surely is needed in a world where the coöperation of great groups may easily submerge the man himself. The farmer has a genuine contribution to make to a fuller democracy.

\section{SOME QUESTIONS ARISE}

But will American farmers coöperate? There is no doubt but the American farmer instinctively and traditionally prefers the independent method of work. Yet for fifty years he has recognized the growing need of collective effort. As a matter of fact a complete census of organized activities among our farmers would reveal a stupendous development of coöperative endeavor. Our country is so big, the needs of different sections so 
different, that we see only parts of the whole. The coöperative work of farmers is done quietly as a rule. It does not easily gain publicity, especially in cities. The most serious phase of the situation is that there is nowhere a big, comprehensive policy with respect to coöperation. We need to know more fully where collective action is desirable or necessary. We need some general overhead plan for the steady, sane, effective development of coöperation in all fields of rural improvement. It is here that the need is greatest and so here the most thought and study should come; here, too, the first steps should be taken. The extent of the farmer's contribution to democracy depends in large measure upon his success in establishing a wise policy of collective action.

Can the city help the country? And will the farmer coöperate with city people and agencies? The city can help the country materially, but only as it attempts to do so in the full spirit of genuine coöperation. Farmers resent "slumming" and "uplift." If it were otherwise we would know that the old-time American farmer had passed away. But even well-meant effort by an urban group often fails because of inadequate knowledge of conditions. It is easy to assume that what has "worked" in the city will work in the country; that the organizing and executive genius that has built huge industries, if applied to the solution of the troubles of farmers, will master the situation; that leadership in agricultural matters, especially in their business aspect, must come from the city; that farmers are in the last throes of despair and need above all else the saving services of organized philanthropy. The farmers in turn find it difficult not to resent any approach from urban interests, even those most sincere and sym- 
pathetic; to be suspicious of some dark plot to entrap the unwary; to assume that all city residents regard country residents as inferior; to be in general unduly class-conscious. There is no doubt but the city can help the country in many ways. It has organizing ability, it has wealth, it has well-developed agencies for both business and social improvement. The right sort of urban aid, from the right sort of people, offered in a spirit of genuine coöperation and suffused with understanding as well as real sympathy, could be vitalized in many rural causes. There is no sound reason why farmers should not welcome such coöperation, and they will do so once it is clear that the offer is sincere and intelligent.

Another question, less frequently asked, is equally pertinent: Can the country help the city? Why not? It already furnishes fresh blood for city building. Were it not for this transfusion, city life would surely deteriorate. The country can endeavor to ensure the health of the migration cityward. The service to the cities and so to the nation which the country is rendering as the nursery of young manhood and womanhood is not sufficiently recognized. The greatest asset of a democracy is people who are healthy of body, intelligent of mind, clean of morals and friendly of spirit. The farms have bred such people and they can and should continue to breed them. It will be one of the farmer's best contributions to democracy. The farmer can help the city by trying to understand the problems of the city. He can support such wise measures of reform as will help the honest urban citizens to put under foot the sinister forces that haunt municipal politics and prey upon the people. Farmers habitually think of these things as not particularly their affair; but it is their 


\section{THE FARMER AND THE NEW DAY}

affair. Both city and country must see their mutual dependence. The national welfare is far bigger than any questions of country or city alone.

Is there a rural aristocracy? It is often assumed that the sharp distinctions between very rich and very poor, which seem so patent in the city, do not exist in the country, and that therefore the farmers show no social cleavages. This is contrary both to fact and to good sense. Every neighborhood has its family or families of comparative wealth. As a rule this wealth is due to superior skill, though sometimes merely to the accident of inheritance. In every neighborhood there are the relatively poor. This poverty is due often to sheer incompetence, but of course also to misfortune. It is idle to deny that there are wide divergencies of capacity, of intelligence, of refinement among farm families, and these divergencies cause certain groupings, classifications, even cliques. The plantation system of the South bred marked distinctions between owner and laborer as well as social antagonisms. In the North the old practice of the "hired man" and the "hired girl " eating with the family tends to disappear. The influx of alien races breaks up the old alignments. But why should we not expect all this? It is a false idea of democracy that fails to provide for the distinctions that grow out of real differences among people. There is a true equality and there is a false equality in a democracy. Moreover, in spite of our best selves, we find ourselves rather proud of such attainments as set us above or apart from the crowd. There is an inhercnt tendency toward aristocracy. At its hest this tendency lies at the root of ambition to excel. The great fact about formers in this connection is that in snite of natural differences and inequalities, there is a certain 
friendliness, common dealing and mutual understanding in American farm life that is not duplicated anywhere else. In a typical and prosperous farming region, say of the Middle West, we get as much democracy in the social sense as we will ever get anywhere.

We must recognize that the last decades have, however, seen the beginnings of a possible stratification of farmers which may soon become a real menace. Its sharpest challenge is the widening chasm in wealth, intelligence and interest, between the fortunate and efficient farmer of high-priced fertile land, and the discouraged, transient tenant who tries without capital, without credit and sometimes without either intelligence or foresight, to make his living from the soil.

Will farmers use experts? This is one of the most important questions in a democracy. The old idea of democracy stressed the notion that all men are equal. Consequently the average man might be considered capable of performing all the offices of democracy. This doctrine has a powerful hold upon the American farmer. It is born in part of a wrong idea of democracy and in part of good sense. Democracy does not level all men to the same talent - some have ten talents and some have but one. It is mischievous to hold that the man without special fitness or even without special training can do a certain.piece of work as well as the one who has fitness or training or both. In other words, the expert or specialist is just as important in a democracy as he is in a highly organized autocratic state. On the other hand, specialists are fallible and sometimes narrow. The farmers are using experts probably more freely on the whole than is any other group of people. The agents of the United States Department of Agriculture and members of the staff of 


\section{THE FARMER AND THE NEW DAY}

agricultural colleges and schools and the county agents employed by the farm bureaus, as they go in and out among the farmers, have won their respect and regard ii performing for the farmers a very real service. Thus far, however, the use of the agricultural specialisi $i_{3}$ found chiefly in the field of production, but he must be utilized also in helping to solve the great problems of distribution of food and of country life. It is unfortunate that during the war the fairly large, well-trained, clear-headed group of agricultural economists in this country has not been utilized in connection with the food supply program to anything like the extent that they should have been. We still have a long way to go in making democracy efficient. The farmers, however, are more and more willing to follow the advice of the asfricultural specialists.

Will the farmer lose his strength as an individual in a more compact organization of agriculture? There is danger, no doubt. Organization, it is clear, does tend to submerge the individual, but only where organization is faulty. True organization means the best possible utilization of all the factors that are arailable, and of course the biggest possible man is a prime factor in any enterprise. In other words, if organization is used merely to get material and immediate results without regard to what happens to the individuals concerned, then it is faulty and bad. But true organization takes a long look ahead and values the growth of a man more than it values his product.

Should farmers go into politics in order to aid democracy? Politics is really only a means to an end. We assume the need of honest and efficient government, but that is or should be merely a matter of good machinery. Laws and their administration deal funda- 
mentally with two main human interests, the distribution of wealth and the increase of general welfare. Now if the farmers are to have their share of wealth and if they are to obtain for themselves and their families all the opportunities for welfare that they deserve, they may have to bring pressure to bear upon state and national legislation. Permanently, there can scarcely be a place for a farmers' political party, but there will probably always be a place for a fighting farmers' organization. To this extent, farmers must go into politics.

We must not fail to realize that the development of the real local rural community is pretty much the key to a successful democracy in rural affairs. Over and over again should be emphasized the fact that this local community has in it all the possibilities of democracy. It is, indeed, the unit of democracy.

And finally, is there any relation between democracy and Christianity? The most ardent supporter of democracy ought to be the church. True democracy is but the application of the principles of brotherhood to the work and life of the people. It would be a great gain if those who are interested in securing industrial and social democracy for farmers could clasp hands with those who seek to fully Christianize all rural communities. A true and full democracy is identical with the Kingdom of Heaven on earth. 


\section{CHAPTER XIII}

\section{AN AMERICAN PROGRAM OF RURAL RECONSTRUCTION ${ }^{1}$}

THE American farmer has never failed to meet all the issues of the highest patriotism. In days of peace, he has done his full share in the conquest of a continent for man's use, in helping to feed the world, in perpetuating and extending free institutions of government, universal education, and ideals of a high morality in home and community. In times of war, though a lover of peace, he has responded to the need of the hour with promptness and effectiveness. At Concord, he "fired the shot heard round the world." In our Civil war men of the soil on both sides formed the majority of the fighting forces; to-day their sons and grandsons are in France. In the present crisis the farmer has rallied to the call for labor and sacrifice in his own field of work. He has enlarged his acreage of crops and sought, under great difficulties, to increase his yields. He has fed his own armies as well as the civil populations of his allies.

In common with the men in other great classes of our people who have believed themselves handicapped in their work and life, the American farmer has felt the recent stirrings of important changes in world affairs. He realizes that the war has been fought for a truer freedom, a more real democracy. He has faith that the common man is to have a better chance; that the

1 This chapter is in some sort a summary of the whole book; consequently, many apparent repetitions occur. 
vital privileges of the few are to spread to the many; that the competent are to share with the less competent; that the masses of the people are to have larger responsibility and more effective voice in determining not alone their methods of government, but the conditions under which they work and live. He is conscious that men of all races, realizing the flaws in their mode of living together, are determined to plan a better civilization, to reconstruct, if necessary, the very foundations as well as the superstructure of society.

The American farmer insists that as a matter of mere justice he shall become a beneficiary of this proposed rebuilding of human institutions. He is not willing to admit that it is a problem which concerns only or even chiefly the so-called "laboring classes." He himself is a laborer, a member of a group of industrial workers more numerous than those of any other great occupation. He is aware that in some countries the farmers outnumber all other workers combined. His work is fundamental to all other work. He not only feeds the world, but he furnishes vast quantities of raw material out of which are fabricated clothing and similar indispensable supplies. Poor farming in any nation is disastrous to its industry, and disadvantaged farmers are a menace to any civilization. Moreover, the rural peoples have a contribution to make to a better form of society. Country life of the right sort breeds men and women who hold firmly to ideals of freedom, of thrift, of moral responsibility. The farmer's voice then should be heard in all councils designed to discuss and provide for social reconstruction. He has a right to be heard where his interests are at stake and a duty to act where his service can forward the progress of humanity. 


\section{THE FARMER AND THE NEW DAY}

\section{THE FARMER'S HANDICAPS}

The chief complaint of the American farmer is that his class as a whole does not receive an adequate financial return for capital used and labor expended. In every farming community there are prosperous farmers; and there are entire regions in which, at least during the past two decades, probably a substantial majority of the farmers have made a reasonable profit. But the net income of perhaps five millions of the seven millions of farmers of the country is pitifully inadequate for meeting even the minimum needs of a family in civilized society. This is not all. There exists a universal belief among our farmers, a conviction substantiated by economists, that few farmers receive for their products that share of the retail price which a sound and economical system of distribution would give them. This lack of due reward is not the whole of the rural problem, but it is the most serious specific defect in agricultural affairs.

Some of the farmer's difficulties are chargeable to the nature of the industry. Nature furnishes the essentials of crop and animal production - soil, moisture, air, light, heat, fertilizing materials. But from the same source come flood, drought, extreme heat and untimely frost, pests and diseases of plant and animal, hail, lightning, and tornado. It is true that in those areas which men have found immediately adaptable to agriculture, through a series of years and with respect to most crops at all suitable for given regions, "fair crops" are quite certain. But for the individual farmer or for whole groups of farmers or for specified crops, the uncertainties of yield are not only proverbial but disconcerting, if not serious. Farmers do business 
on so small a capital and so slight a margin, that one season's failure often measures the difference between success and failure in the enterprise. In a country of rapidly increasing population and cheap land a great deal of relatively inferior land comes into use. Inevitably the farmers on this land feel at times the pinch of untoward circumstances. The isolation of the farmer as an individual and of the farming class as a group, brings in its train certain handicaps in the way of inadequate information, difficulties in collective effort, separateness of interest, and sometimes narrowness of outlook.

It would be idle to deny that some of the farmer's troubles are due largely to his own deficiencies. Farmers are of all degrees of capacity. Sheer ignorance, unwarranted prejudices, undue conservatism, unwillingness to coöperate, unwise use of land, inferior business management, mere poverty of neighborhood life and incentive due to lack of vision and of ambition - these have all played their part in the drama of rural discouragement. But it is equally true that farmers have been subject to an unusual extent to certain handicaps that arise from social arrangements. It is, for example, becoming more and more difficult for the landless farmer to secure land and requisite capital for the best use of land on terms that give him a fair chance for eventual ownership. The existing system of distributing food products from farm to household is in many respects exceedingly efficient; it is also in many ways costly and wasteful. But the principal charge to be brought against it is that it has been organized entirely apart from the interests of the producers, and often with the apparent purpose of deliberately crowding the farmer to terms that represent his dire need rather than 


\section{THE FARMER AND THE NEW DAY}

his just reward. In general the present system of distribution of soil-grown prolucts is the main handicap of the American farmer. About this cluster many subsidiary difficulties. The system also illustrates another serious disadvantage. Farming originally was an individual business. As a producing factor it is likely to remain so to a very large extent; but gradually the farmer's market has come to be a highly organized, widespread and complex affair. The single farmer finds himself dealing in both purchase and sale with great combinations of men and capital, and often in competition with millions of fellow farmers similarly situated. His products are bought, manufactured, stored, transported, sold to jobbers and to retailers, and even to ultimate consumers, by powerfully organized agrencies. These agencies are financed by banks whose interest in the farmer is only incidental. The place of foodstuffs in foreign trade is rarely determined by the farmers themselves. And a crowning handicap is that the farmer is seldom represented, even indirectly, in those groups that determine governmental, lusiness or social arrangenents affecting his well-being or in which he has the interest common to citizenship in a democracy. It would be utterly misleading to assert that the American farmer has been neglected by his government, but it is perfectly evident that government has quite failed at two points. It has not that close working contact with all the interests of all the farmers that it should have, and it has not correlated even its own activities into a large, far-sighted, well informed, unified program of endeavor for rural improvement. 


\section{THE NEED OF A NEW AGRICULTURAL POLICY}

The older policies in agricultural development must give way to a much wider and far-reaching eifort to lessen these handicaps of the farmer. First of all we must accurately know the handicaps under which the farmer works, to what extent his difficulties are due to causes within or beyond his personal control, and what are due to inequities in his relations with other classes of citizens. We need wider knowledge of rural resources - physical, economic, social - and how best to conserve them. It is vital to a full rural development that the ends to be attained shall be clearly stated and universally understood. To rely for progress merely upon the individual initiative, inteligence, and power of seven millions of farmers is to court disaster. We must invoke collective effort. We must use recognized social machinery, such as government and voluntary associations. These agencies must be efficient for their purpose and loyal to rural interests. No one agency can meet all the needs of rural development. Each must recognize and define its peculiar task and become as effective as possible for that service. All rural agencies, all groups and all individuals interested in rural affairs must work together intelligently and fraternally in an effort to contribute each its share to the advancement of the common aims of all.

All these elements of a rural policy meet at one common point of contact, that is, in a definite and comprehensive program for the fullest possible development of American agriculture and country life. The need for such a program was apparent before the war; the war has made the need startlingly clear. For ameliorating natural handicaps and dispelling ignorance, as 


\section{THE FARMER AND THE NEW DAY}

well as for abolishing unjust discriminations, we need all the wisdom, expert knowledge, skill, judgment, that are available. We have at present no large unified plan for making these factors fully available, nor even for determining the nature of the problems involved. We need therefore an American agricultural program embodying a plan as big as the problem and so practical that it may apply to every region, every type of farming, and to substantially every need of every farmer.

\section{A NEW STARTING POINT}

The war has made clear the need of a fundamental change in the attitude of both producers and consumers of soil-grown products, as well as in the point of view of the distributing interests and of government itself. Heretofore agricultural questions seemed to revolve about the need of increased production as an end in itself. It was assumed that all the soil produced would be used. But the arrangements by which America has contributed its share to the war-made demands for food have implied a direct relationship of an international need for food to an international supply of food. It has become evident that this relationship is not broken as the war closes. The problem of supplying the world's food will be one of universal concern. It will involve the reconstruction of national economy and of international trade arrangements. The world's food supply must therefore be the central question about which will cluster the matters of more immediate concern to farmers - what kind of food is wanted, how much of it and in what form, where can it best be produced? The character of national dietaries should be determined on a thoroughly scientific basis and an effort 
made to educate consumers to intelligent use of food as well as the utmost effort to avoid waste.

The farmer stands ready to revise his plans, if necessary, in order to meet this new departure in the world's agriculture. He recognizes the increasing degree in which non-producers of food and other soil-grown products are dependent upon him. He sees in this independence solemn obligation laid upon him as the trustee of the soil, the steward of an adequate food supply. He realizes his duty not only to grow food, but to grow it with utmost economy and skill, and to be mindful that he does not waste those resources of soil fertility which are a permanent asset of society. But the farmer insists that he shall receive a fair return for his capital and labor. The demand for cheap food should not be carried so far as to produce a class of farmers who suffer from wholly inadequate incomes. The farmer's right to a living wage is as valid as that of any one else. Consumers should realize the economic conditions of the profitable production of food; few of them appreciate the unquestioned fact that they have been "living off the unrewarded labor of farm women and children." While the economic task of supplying the world with food must be considered as a whole, the producers should have both full consideration and proper representation in all those discussions and organized arrangements that deal with the problem as a unit or with any part of it.

\section{ACCESS TO THE LAND}

A true democracy requires that the man who tills the land shall control the land he tills. Control involves not merely the welfare of the man who for a brief time 


\section{THE FARMER AND THE NEW DAY}

uses the land, but calls for the best possible use of the land, the growing of what consumers want, and the utmost conservation of fertility. The economic freedom of the soil-tiller is not only the first term in a permanently efficient agriculture; it is the unquestioned right of the farmer as a member of society. Any approach to economic bondage is to be deprecated, as is also any arrangement that limits the activities, choices, privileges or rewards of farmers, beyond those inherent in a world of fallible men seeking self-interest, but ready to concede a common interest. Ownership of the agricultural land by those who work it is preferable to any other plan. But if for any reason such a policy is inapplicable in all cases, there should be organized a system of leasing by which the tenant receives some of the advantages of ownership as well as of its moral obligations. A tenant should have an opportunity to secure long lease, and should be able legally to gain credit for improvements he has made. The pathway from tenancy to ownership should be made easy. There is no permanent place in America for the absentee landlord, even if he be a retired farmer, yet we must not fail to provide a career on the land for the man of superior ability, the large farmer, provided he farms the land he owns.

For nearly a century the American land policy has been to provide new land for newcomers at a nominal or small cost. The free land of high quality is gone. There are however many millions of acres of dry, wet, sandy and stony lands that can be reclaimed for use. The farmers object to the improvement of this unused land until it is actually needed. It would be well to make accurate and detailed studies of these lands; but no steps should be taken to bring them into competi- 
tion with improved lands until the need is clear. The farmers insist that these improvements, when undertaken, should be performed by the government, in order that exploitation for private profit shall be eliminated. Essential features of the development of new land should include provision for the easy acquiring of adequate capital for operation and the establishment of effective machinery for satisfactory marketing of products and purchase of farm requirements.

\section{SECURING CAPITAL}

When the new land was all but free and little farm machinery was used, the farmer's capital was almost literally his own strong hands and active brain. But present and prospective prices for land, and the cost of necessary improvements and machinery, require considerable capital. Doubtless the majority of farmers are farming with too little capital. Under modern conditions the securing of capital means credit. Until recently the financial methods of the country were not geared to the peculiar needs of the farmer. The Farm Land Bank system goes a long way in the direction of proper terms of aid; it does not however fully meet the situation, chiefly because it does not and cannot aid the tenant or laborer until he has saved a substantial sum; this is often hard to do. There is a gulf here that needs bridging. The only relief seems to lie in a form of direct government loan to men of approved character, to enable them to take advantage of the Farm Land Bank.

Moreover it takes more capital than formerly to "make" a crop, especially as various forms of intensive farming increase. Better seed, more fertilizer, better tillage, more labor, commercial feeds for live- 


\section{THE FARMER AND THE NEW DAY}

stock add to the initial cost. Many farmers are obliged to borrow in order to secure these requirements, and the loan usually takes the form of mercantile or "store" credit. Unfortunately, there are thousands of farmers who are obliged to seek similar credit during the crop-growing season for household supplies. Mercantile credit at its worst is sheer robbery, and even at its best has two serious drawbacks. Actual interest charges are likely to be high, if not exorbitant, and are elusive because hidden in the price. Pressure for payment tends to compel the grower to sell his product at the bidding of his creditor - almost inevitably to the farmer's disadvantage. Our farmers should have a system that suits the need for short term credit for making crops to best advantage.

In all forms of credit to farmers two principles should be more fully recognized by farmers themselves, by bankers and by the government: The great possibilities of capitalizing character, by which a man's industry and integrity become a substantial collateral for loans; and the financial power of the collective assets of a community of farmers, once all its members are willing to share in a common financial responsibility.

There is a form of assistance to farmers, of vastly increasing importance, theoretically belonging partly in the domain of natural resources and being partly a matter of credit, while practically it involves the efficiency of government. The use by farmers of various forms of mechanical power is destined to be a large factor in their enterprise. Public control of water, not merely for irrigation but also for power, is indispensable. The use of electricity on the farm and for the development of community manufactures and similar services, must not be dependent upon the accidents of corporate 
convenience. Collective methods of handling this question by farming communities will prove economical but must have legislative encouragement.

\section{FARM LABOR}

The use of machinery decreases the need for farm labor but does not eliminate it; and it increases the demand for skilled labor. The call for labor in other industries, with apparently higher wages, shorter hours and more sociable conditions of life, competes most seriously with the farm. Farm boys are longer in school than formerly and we would not have it otherwise. Neither are we prepared to urge a large use of woman's labor on the land as a permanent feature. The seasonal need for labor on all but stock farms is another difficulty. Altogether, the farm labor problem is perhaps the most serious which the farmer must face.

Some remedies seem clear enough, but how to secure actual relief is another matter. Evidently, as a principle, the farmer must gain access to the world's labor and procure his share of it. To do this, he must pay such wages and grant such terms as will make him a competitor with other industries. The housing and other living conditions of the laborer must be in keeping with modern requirements for comfort, convenience and health. More machinery must be used for more purposes. Skilled and even trained farm labor must prevail. All this requires such prices for his products that the farmer can afford the necessary labor cost. Ideally it implies also a transient farm labor group, whose members, skilled, intelligent and ambitious, will rapidly pass up to tenantry and ownership of land. This problem can be met only as the government, 


\section{THE FARMER AND THE NEW DAY}

coöperating with powerful associations of farmers, shall study this difficulty thoroughly and seek to handle it in terms of some large, nation-wide policy.

\section{PROBLEMS OF PRODUCTION}

The character of the problems which confront the farmer in his work of producing crops and animals is fairly well understood. The farmers themselves have been on the whole keen to improve methods and they have had far more aid from scientists in this field than in any other. Preparing the soil, cultivating, fertilizing, adapting it to certain plants; increasing crop yields and improving quality by seed selection; seeking better varieties; constant improvement of farm animals by breeding, feeding and attention to health; protecting both crops and animals against diseases and pests - we are dealing with all these needs. The requirements of the future are a greatly enlarged and better correlated national system of research into fundamental scientific principles, a wiser and more wide-spread testing of theories in actual farm practice on a commercial scale, and far better organized educational "drives" or "projects" for bringing not only the mind but also the will of the farmers to practice the best methods.

\section{FARM MANAGEMENT}

Farming, even to-day and by great masses of farmers, is thought of chiefly as growing crops and animals. Only slowly have we come to realize that the good farmer is actually not only a skillful handler of soil, plant and animal, but that he is also a good manager. Genuine business skill, executive ability, the power to organize all the factors of the farm into a unity, probably are far more important than any other one ele- 
ment. Failure here is much more frequent than poor practice. Most unsuccessful farmers cannot manage. Such questions as size of farm, amount of capital needed, laying out of the farm itself, kind and convenience of buildings, saving motions in labor operations, filling in idle hours, keeping of accounts, economical buying and skillful selling, wise reinvestments of profits - these are matters too much neglected by many farmers. An adequate system of investigation and popular education is called for.

\section{THE DISTRIBUTION PROBLEM}

Here we reach the real core of the farm problem on its business side. Frequently a farmer finds a whole season's labor gone for naught, because he must sell at a price that barely meets the expenditures for mere growing of the crop. He has little voice in establishing the price. There are two fundamental difficulties which the farmer faces. The price of his products is determined largely by variations in the supply due mainly to the weather and to fluctuations in acreage. Then, again, the individual farmer sells and buys in organized markets. He pits himself against combinations of men and capital, and his struggle is futile. Production is a matter of the individual farm and the amount is negligible in any market. He may have neither knowledge, skill nor facilities for meeting the requirements of the market as to condition and form of product. The small farmer cannot sort, grade, pack, store or transport to advantage. It happens, therefore, that the price he gets may have no relation whatever to cost of production; often it has no relation to true market values.

It has been the habit of farmers for many years to 


\section{THE FARMER AND THE NEW DAY}

charge their disappointments in marketing to the middleman. Even the complete abolition of middlemen is advocated as a prime remedy. Rascally or incompetent handlers of farmers' products there have been a plenty. Doubtless there are too many distributing agencies. But middlemen are indispensable; they have a real economic function.

Transportation obviously plays a vital part in the marketing of farm products. Poor highways have cost and are costing our farmers millions of dollars. Railway freight charges have frequently been purely arbitrary, bearing slight relations to cost of service. Farmers living near a large market are obliged to pay as much for transporting their products as is paid by the grower in a far distant place. Over-competition between different farm regions has resulted. The reshipment of both raw and manufactured farm products has built up transportation charges enormous in the aggregate.

The farmers demand, therefore, a thorough reorganization of the entire business of selling farm products, in the interests of both the farmers and the consumers. There should be full standardization and the utmost economy in all the processes of marketing. Harvesting, collecting, grading, packing, storing, transporting, and city distributing should be submitted to well-organized and efficiently managed enterprises. A well-planned effort should be inaugurated to adapt each natural agricultural area to its best possible uses. To such an extent as is practicable, consuming centers, even large villages and small cities, should be provided with their food products from the farms adjacent. The local manufacture or other preparation of farm products 
should be encouraged as a possible economy in transportation.

For these ends, we must rely first of all upon existing agencies. The present machinery of preparation and distribution of soil-grown products should if possible be socialized, made to serve more fully the mutual interest of producers and consumers. Those private establishments that deal with the slaughter and distribution of meat products; grain elevators and mills; cotton gins; sugar factories; and all other converters of farm products into forms for consumption; storage and warehouse concerns; commission men and all wholesale and retail distributors must bend to the demand for service in the public interest. The farmer insists that the normal and legitimate machinery of the market shall not be prostituted to merely speculative or gambling methods.

It is beyond question that such ends can be gained only by intelligent, fair, but rigid control by adequate law and administrative rule. It may also require a measure of government ownership and management. The American farmer will not ask government for this service if it can be given through private agencies. But he will insist that it be given. And if the aid of government must be invoked, he will not be deterred from his demands by fears of any theory of social organization. He wants fair dealing, substantial justice in this realm where his very existence is at stake.

\section{COLLECTIVE BARGAINING AMONG FARMERS}

Farmers are coming to realize more keenly that in the long run, the responsibility for a reasonable financial return for their labor depends upon themselves rather than upon the attitude of other interests or upon 


\section{THE FARMER AND THE NEW DAY}

government itself. The individual farmer is well-nigh helpless in dealing with a world-market. But the collective business power of seven million farmers, intelligently and fairly applied, is almost irresistible.

The independent farmer has preferred to bargain for himself. In the old days, and in some cases even now, this was advantageous. But as a rule the farmer has no chance to make a good bargain. It is only as he shares with a group of fellow farmers the responsibilities of proper preparation of products for market, and participates in the pooling of sufficient quantities to constitute a unit of product large enough to attract attention on the market, that he becomes relatively independent. Only then has he any chance to make a real bargain, a fair trade. No legislation designed to control corporations dealing in farm products, no aid, subsidy or other form of governmental enterprise, however necessary and useful, can take the place of the establishment of a wide-spread organization of producing farmers into groups fitted to buy, sell and otherwise to do business coöperatively.

It becomes necessary then for the American farmer to move rapidly toward such a form of effort as will enable him to join hands with his fellows in all legitimate and reasonable methods of collective bargaining. National and state legislation should not only fully recognize but frankly encourage this method of association. Agricultural colleges and schools should investigate and teach the best methods of business coöperation in agriculture. Government agencies should be provided to assist by advice, information, law enforcement and, if necessary, by advances on stored products. Government should ensure a free field for coöperative 
effort among farmers and prevent discrimination by railways, middlemen or others.

\section{AGRICULTURAL INSURANCE OR STABILIZATION}

Great variations occur from year to year both in amount of farm products and in their market value. Diseases and pests, "bad" weather, climatic catastrophes, speculation in food products, forced sales due to inadequate capital, market gluts, all play their part in this unstability. An adequate program of rural reconstruction requires the consideration of the feasibility of establishing stabilizing influences and devices that will tend to reduce the element of mere chance in the foodproducing process. Such a movement is in the interest of consumers as well as producers. There should be an effort, through government aid and supervision, and partly by large coöperative associations of farmers themselves, to secure the adjustment of acreages to demand. Government should also encourage regional self-support in certain products; crop insurance against diseases, pests, hail, drought, wind, lightning, frost, flood, and animal insurance; more opportunities for short term credit for purchasing supplies needed in high-grade production; advances to farmers in products in storage; progressive release of stocks as needed by the market; full market news service.

\section{AGRICULTURE IN INTERNATIONAL TRADE}

The interests of the American farmer not only call for an adjustment of his business to the world's demand for products of the soil, but require such an adjustment of all the parts of trade relations among nations as shall be just to him. It is fundamental that in every 


\section{THE FARMER AND THE NEW DAY}

country agriculture shall be regarded as a primary industry, to be as fully cherished and protected as any other industry. Elementary economic principles, however, assert the unwisdom of carrying this process so far as to seek complete national independence in soilgrown products. It is perhaps possible for each country to feed itself, but is it wise for it to do so? The world's food should be grown where it can be grown to best advantage to the world as a whole. If manufactured goods are sold in countries largely agricultural, they must be paid for chiefly in farm products, which in turn must compete with those grown at home. Exchange of goods among nations makes for economic prosperity as well as for permanent peace. The American farmer is willing to coöperate in a world system of fair trade. But he insists that agriculture must be fully considered in all international trade arrangements. It is merely justice that proposals for tariffs, subsidies, preferential arrangements should be made only after thorough study has revealed their prospective bearings upon American agriculture, and only with the consent of the American farmer

\section{AN ADEQUATE SYSTEM OF RURAL EDUCATION}

The United States has been singularly alert in the development of plans for agricultural education. The federal Department of Agriculture, the great sisterhood of state agricultural colleges and experiment stations, and the wonderful system of extension education just now evolving through the coöperation of these agencies with the county farm bureaus, comprise a scheme of educational activities on behalf of the farmer unapproached elsewhere in the world. Yet we have not secured all that we need. The farmer himself has 
abundant faith in education as a solvent of his difficulties, and he demands that agricultural education shall not only be completely democratized and adapted to the last man on the land, but that it shall be as broad in its content as the entire range of the rural problem. There should be in the early future a very large increase in the number of agricultural schools. Eventually, these schools, meeting the needs of boys from I 4 to 8 years of age and designed chiefly as finishing schools, must be relied upon to furnish the big majority of school-trained farmers. The control or regulatory tasks in agricultural enterprises carried on by the state should be more carefully separated from its educational work. The agricultural colleges cannot fulfill their true mission to American farmers unless they seek and secure a vast enlargement of both their investigational and teaching work in the realms of the economic and social problems of agriculture. The present divided administrative responsibilities for schemes of agricultural education should be coördinated in some fashion, so that we may have a truly national system of agricultural education. At present the United States Department of Agriculture, the Bureau of Education, the federal and state boards of vocational education, the agricultural colleges, state commissioners or boards of education, county farm bureaus, local public school authorities, and in some cases independent agricultural schools, are all involved in managing educational enterprises on behalf of agriculture. They should be brought into the closest coöperation. The system as a unit must make its utmost contribution to the solution of all phases of the rural problem. It must do all that education can do for the farmer. A great degree of centralization is necessary with regard to a large gen- 


\section{THE FARMER AND THE NEW DAY}

eral policy in research, in relating parts of the system to one another and to the whole, and particularly in extension teaching. But bureaucratic methods should be avoided and the widest liberty recognized as a right of the local establishment.

The rural school system needs a complete overhauling. First of all, we should have a national rural school policy and program, formulated by educators in close sympathy with rural affairs, but with the approval of representative farmers. In most states a larger measure of state aid for small schools will be found necessary. The American farmer believes in the essential justice of the dictum, "All the wealth of the state must be available for the education of all the children in the state." The country child is entitled to as good an education as the city child. We may find that appropriations from the federal treasury are necessary in order to secure adequate state support and full recognition of rural school needs. There is little doubt that the consolidated school offers manifest advantages over the traditional one-room district school and should soon become the prevailing type of rural school. Better paid and better trained teachers, greater permanence of tenure of teaching, closer and more consistent supervision, redirection of studies to meet the peculiar needs of rural pupils, are essential to efficiency. One of the most serious defects in our rural school system is the lack of good high schools. Provision should also be made for continuation or part time schools. Moreover, the schools should be used as centers for adult study through lecture courses, reading clubs, study clubs, correspondence courses; they should minister to a great advance of solid study and thinking among the farmers and their families, not only on agricultural 
themes, but in the fields of citizenship and of literature and art. The entire farming community should be perpetually at school.

The function of education in a rural democracy should be conceived in no narrowly vocational or materialistic spirit. The making of more efficient farmers is one great end to keep in view, but it is only a part of the need. Farm bred boys and girls must have the same chance to secure an adequate education for city occupations that they should have to study agriculture. City bred boys and girls should have the chance to learn farming if they care to. There must be no class or caste lines developed by our educational system. Understanding of the entire farm problem, appreciation of the importance of a satisfying country life, love of the land, a sense of the farmer's duties as well as his rights, delight in good literature, clearness of thinking about all the problems of democracy at home and abroad these should be the fruit of a well-planned system of rural education. Leaders, too, must be trained for rural service. Agricultural experts must be educated and given a place to work. A rural democracy can be efficient and free only through education.

\section{THE VOICE OF AGRICULTURE}

One of the most enduring results of an adequate system of rural education should be seen in the increasing ability of the farmers to maintain their ground in all those councils in which their interests are discussed and decided. It should be a fundamental principle that no state or national legislation, no project of a publicly supported agency involving the coopperation or the larger interests of the farmers, no enterprise inaugurated by associations of a general business or urban 


\section{THE FARMER AND THE NEW DAY}

character, should be launched until authorized representatives of the farmers have been consulted. A huge scheme for reclaiming great areas of new agricultural land involves added competition. Laws taxing land improvements put a burden upon thrift and tax productive power. Even the legitimate organization of labor may disregard the farmer's welfare. If the commonwealth deems social amelioration to be sound policy, it should be adapted to the needs of the farmers. The extension or restriction of foreign trade affects agriculture profoundly. Consumers of food have a right to coöperate in order to save in purchase price, but they should understand the terms of a fair bargain with food producers. Right-minded farmers welcome the aid of the individuals and associations of the cities, but resent condescension or philanthropy - "benevolent urbanism." If there should be a struggle between a demand for cheap food and the resulting danger of putting cheap men on the land, the interests of farm as well as of the nation as a whole would be against too cheap food. Farmers cannot afford to agree to a scheme that brings into activity more producers of food than are needed or that causes loss of profits to those already on farms. Under a system of utmost economy in food distribution, the farmer must share the gain with the consumer. The country village and small city must cease to exploit the farmers of the surrounding country. Immigration laws must consider the country as well as the city. These are but a few of the many interests of the American farmer that are habitually disregarded, usually in sheer ignorance rather than of intent, but largely because the farmers do not have authoritative spokesmen in close touch with the men and the agencies that determine policies 
in fields of effort that involve agricultural interests. But it is not alone with respect to his own interests that the American farmer needs a place at the counciltable. Rural public opinion should share in national and even international affairs. The farmer should speak his views concerning the need and terms of permanent world peace, the policies of trade and of treaties, all economic, political and social arrangements. $\mathrm{He}$ is an organic part of the structure of society. His is the most numerous class. His views, his ideals, his ways of thinking should have full weight in the common concerns of all mankind. A full democracy cannot develop unless the farmer makes his special contribution, and this he can not do if he is voiceless in the counsels of democracy.

There are two main channels through which must ebb and flow the tides of rural endeavor both in assisting farmers to solve their particular problems and in receiving from farmers their special contribution to the world's welfare. One is government, including legislation as well as all those agencies of regulation and education that receive public support; the other is mutual association, by which farmers band themselves into groups large and small for their common welfare.

\section{THE GOVERNMENT AND AGRICULTURE}

It is maintained by some students that there is an increasing tendency among all people to regard government or the state as a sort of huge person that stands out apart from people as individuals. This person has great power, makes its own morality, must be obeyed. Sometimes this idea is carried so far that the state assumes a morality of its own, denying the application to its acts of the laws of personal righteousness; 


\section{THE FARMER AND THE NEW DAY}

on the other hand individuals may cheat the state if they can. But what seems to be a better conception of government is that it is simply all of us together seeking through common activities the highest good of all. Compulsion may be necessary as a means of securing the support of the thoughtless, the ignorant and the willful. But the essential idea is one of common action for the common good. Laws are merely expressions of the common will for the common wealth and the common welfare. It seems clear that a true democracy must hold firmly to the idea of government that regards it as merely one of the ways in which people act together for mutual interests.

This distinction in attitude toward government is vital. There is much discussion about what government should do and should not do. If government is a superman, a separate power, something above and beyond the all-of-us-together, then we may well insist on limitations to its activities and requirements. But if it is truly the rule of the people its activities are to be judged purely by their effectiveness. We are not to urge that government do this or do that merely because we have a blind faith in some superior wisdom residing in the state; nor do we refuse to ask government to do other things merely because we fear socialism or any other "ism." There are but two questions to be answered when governmental activities are up for consideration: (I) On the whole is governmental activity - whether law or regulation or management or actual ownership - most effective in gaining the ends which the people really want and need? and (2) in the longer view does this activity make the people themselves stronger or weaker in foresight, judgment, initiative and general intelligence? 
If this view of government is truly the democratic view, then what such a government shall do for agriculture and country life must meet the tests of these two questions just asked. The answers vary from decade to decade. What may be well for government to do to-day may perhaps better be left to-morrow to mutual associations. In the immediate future, in the days of reconstruction that must follow the close of the great war, certain demands upon government may fairly be made by the American farmer.

Government may well foster agriculture to the uttermost. The food supply is fundamental. Food is now produced and will always be produced by a vast number of small, more or less scattered producers. Self-help through associated effort is more difficult for this group than with any other large class of people. Government can not remain indifferent to the needs of agriculture. It might well be justified in doing more for agriculture than for any other industry.

Emphasis has already been laid upon the need for an enlarged and more systematic scheme of rural education. Education must be defined in a very broad way, to include all efforts, however informal, to reach the working farmer. Far greater attention must be paid to the extent and type of information that is spread among the farmers. If we are to have an effective agricultural program, we must enlist the farmers all farmers if possible. They can not blindly coöperate in or even subscribe to policies. They want to know both facts and principles concerning all parts of their complicated problem. It is not enough to teach the care of soil and plant and animal. The principles and practice of farm management, ample facts concerning prices, markets, food demand and supply, the 


\section{THE FARMER AND THE NEW DAY}

best type of machinery, in fine all the economic and community problems are of supreme importance. Government should deliberately encourage discussion among farmers of the larger phases of rural policy the laws of diminishing returns and of land rent, regional competition in products, international relationships in food supply, the big factors in soil conservation. The publicly supported educational agencies in a democracy can not fail to carry the farmers as a class to a fuller knowledge and keener understanding of the big as well as the small questions involved in a sound program of rural development.

Legislation is the only way by which the government can carry out its objects. The kind of laws affecting agriculture which are enacted by the nation and the states, is of greatest moment. These laws will be numerous and will change with changing needs. But certain principles may be insisted upon. There should be laws encouraging to the greatest possible extent collective bargaining or coöperative business methods among the farmers. The farmers cannot complain of reasonable laws restricting their activities - as inspection of dairies - in the interest of consumers, provided there is equally effective protection against unfriendly and unfair dealings. The farmers' interest in taxation, tariffs and other trade regulations, monetary systems, and in fact all economic and social legislation is fundamental and not to be disregarded. It may be found impossible at times for farmers to get " a square deal" in business, even when they are well organized. In such event there should be no hesitation on the part of government to provide at public expense those facilities - such as public markets, elevators, storages - that private management has 
abused. Interstate and international arrangements affecting farmers must of course be made by the federal government. Land development projects, if under private auspices, should be regulated in the public interest. The exploitation of would-be settlers should never be permitted; if necessary, the government itself should control absolutely the redemption of unused lands and their sale to farmers. Local government in rural areas is capable of greater efficiency and particularly may enlarge in functions for the public good.

While laws lie back of all governmental activity, as public agencies multiply and enlarge, administrative rules and policies increase in importance. The question of administrative efficiency therefore becomes of prime consequence. Unless able, well-trained, honest and far-visioned men are in control of public agencies and are encouraged and aided by the farmers themselves, governmental effort must necessarily be weak and ineffective. These officials must have a measure of freedom as well as of responsibility. Petty restrictions of a clerical sort cost terribly in real efficiency.

The United States Department of Agriculture, with its coöperating allies, the agricultural colleges and the county farm bureaus, has become a gigantic institution. Its responsibility for leadership is as great as its size. It should assist the farmers to determine policies. It should keep men in all countries studying tendencies and methods. It may well seek to secure unity of effort on behalf of big projects of improvement.

Government has its limitations. These should be frankly recognized and so far as possible removed. The tendency is for the methods of government to become bureaucratic, dilatory, inflexible, unadaptable. Laws themselves are often unwisely drawn, and limit 


\section{THE FARMER AND THE NEW DAY}

the action of administrative officers. There is a necessity for a certain amount of system, order, precedent and rule, but these easily degenerate into mere machinery. Laws have to be interpreted, often by men without insight into the need of the farmer or even the true intent of the lawmakers. The personnel of responsible government officials changes. New men may bring new ideas, but may also have faulty ideas and inadequate training or a limited point of view. Moreover, no public agent can speak permanently and fully for the farmers in a democracy. His words may be wise, his intent honest, and his judgment sound, but he does not fully represent the farmer. Excessive governmental activity and constant dependence upon government may check initiative and real power. There are important fields that no government institutions can cultivate for example, the desire of farmers to take political action, and the sway of the religious motive.

\section{AGRARIAN ASSOCIATIONS}

After all the farmers must direct their own destinies. The best service that government can render farmers is to help them to help themselves. The paternalism of the state and the gratuitous benerolence of the city are equally futile in the building of a rural democracy. The coöperative efforts of farmers are indispensable to real rural progress. Whether in securing better farm practice, or in obtaining more satisfactory profits, or in evolving a better country life, the collective intelligence and planning of the great masses of farmers should be added to all investigation and teaching by specialists, all projects of government, all the work of school and college, all laws for regulation or control.

The farmers must "organize" first of all for self- 
protection and self-help. The lone farmer is always at a disadvantage. Predatory interests must be met by a determined front. Farmers must have the chance to express their own convictions. Class power and efficiency show themselves best in capacity for self-direction. Only through association can farmers defend themselves; only so can they make their fullest contributions to the general welfare. There is danger in organization. The individual may lose himself in some big overhead attachment. Powerful combinations of farmers may exercise their power wrongfully. But the gains are far greater than the losses. The farmer has been called the most independent of men; but alone he is no longer independent. He becomes truly free, under modern conditions, only as he joins with his fellows for common ends. The dangers arising in associated activity from impulse or ignorance, selfish class interests or feeling can be met by education, time and experience.

Though it is doubtful if a farmers' political party can have any permanent place in America, the farmers must be free to act together to influence parties, measures and men. There should be room in the rural program for a fighting force of farmers. The need for such aggressive tactics may arise only occasionally; but sound policy calls for its recognition. But rural associations do not exist for their own sakes. They must seek to serve. They must not be narrow in their views or in their activities. They are for the good of all or they are no good at all. They must be ready to coöperate heartily with one another and with public agencies. They should become as efficient as possible, each doing its own part in the program of rural betterment. 


\section{THE FARMER AND THE NEW DAY}

\section{THE ORGANIZATION OF AMERICAN AGRICULTURE AND}

COUNTRY LIFE

We cannot have an adequate rural policy unless we think of American agriculture as in some sort one big farm, with millions of fields, each tilled by a farmer and his family. How can we get all these millions of farmers to work hard, intelligently and continuously, in such a way that the entire American farm will reach its highest possible development? The only method by which this can be even approximated is organization. Organization secures the coöperation of all factors that are necessary or helpful in carrying out a definite purpose. The full organization of American agriculture and country life is the largest single item in making a sound policy effective. How can agriculture be thus organized?

Each agency or institution devised to assist farmers and farming should work out a clearly marked policy and program. Its particular task in rural improvement needs to be defined and recognized. A particular form of organization, as yet not fully utilized in America, is the thorough coöperation of the growers of a particular product, as of cotton growers, wheat growers, stock-breeders, in all parts of their business - producing, selling and establishing relationships to other interests or to government. Industrial solidarity seems necessary for greatest coöperative effectiveness. The citrus-fruit growers of California have shown the way to one of the most important and promising methods of agricultural advancement.

Certain objects or purposes require another grouping of people and of agencies. The country life movement calls for common action by those whose chief in- 
terest is social welfare. Or a more specific end may be in view, such as an apple producing campaign. Or in even greater detail, it may be desirable to have a "drive" for treating potato seed. In all these cases the coöperation of many agencies is necessary for the best success. Many things need to be done - investigation, an educational propaganda - certain public regulations, buying and selling. Many agencies should be used - the extension service, the farm bureau, the Grange, the fruit or vegetable growers' association, the farmers' exchange. In some way all necessary methods and agencies are to be used, each in its best way, for the purpose in view.

Still another type of rural organization is to be developed. Unless agriculture and country life are fully organized by regions or areas, the most complete progress can hardly be expected. How can we bring the farming business and the farm life to its best estate in each farm, in each farm community, in each rural county, in each state, in the nation as a whole and in the world at large? Any aim short of such an idea is incomplete. Each region then must become a real unit for rural progress, must study itself, make plans for improvement, and ally all forces within the region in a broad program of development. This is really the crowning task of statesmanship in rural affairs.

\section{BUILDING THE LOCAL RURAI COMMUNITY}

In some respects the most important single improvement in rural affairs is to develop real communities of farming folk. These communities must often be created - they do not exist. The community idea is simply that of a group of farmers and the people closely allied with them, acting together as one man. The 


\section{THE FARMER AND THE NEW DAY}

members of this local group can plan as a unit in production of crops, agreeing on kinds and amounts. They can sell together and buy together. They can act together in school and church attairs and in matters of public health. A community may have its own ideas and ideals, its own church, school, farmers' exchange, library, in fine all organized activitics that seem necessary or desirable. The local community is almost essential in a real rural democracy, and indeed is the unit of democracy.

\section{COUNTRY LIFE}

In any program of rural reconstruction that aims to be comprehensive it would be a fatal blunder not to stress the importance of the social or humane factor. The life is more than meat. The man is worth more than dollars. "The farmer is of more consequence than the farm and should be first improved." The big farm question is getting and keeping the right sort of people on the land. A satisfying farm life is necessary to a permanent agriculture and consequently to the best farming. The city will always be replenished from the country-side. We must therefore omit no plan and decline no exertion that will encourage a good farm life through such elements as:

A farm home that conserves the physical vigor, the mental development, the moral character and the spiritual insight of all members of the family, whether workers or growing children, and plays its part in developing a rich community life.

A mechanism of communication within the community and with other communities that serves both economic and social needs. 
A system of rural education that gives a sound foundation in the recognized elements of the efficient worker, the intelligent citizen, the high-minded man.

Conservation of the health of the people; proper provision for public sanitation.

Machinery of local government at once honest and effective for large community ends as well as for maintenance of order.

Ample recreation, native rather than exotic - spontaneous, but directed, for the young; self-expressive for the mature.

A rural art that develops the full capacity of the farm environment, making beauty of dwelling, roadside, field and broad landscape an asset of farm life recognized by the farmer himself.

A rural culture that appreciates the full meaning of life and seeks constant development of mind and spirit through work, books, nature, human companionship.

Moral conditions that make for training of children in the best habits of conduct.

The religious motive that idealizes farm work as service to God and His children, land management as social responsibility and rural life itself as a sacred opportunity for personal joy and growth.

\section{COUNCILS OF AGRICULTURE}

There can be no consistent rural policy unless there is a policy maker. But there is no existing agency wise enough or representative enough to make a policy. We have many agencies, public and private, and will have more rather than fewer of them. How then can 


\section{THE FARMER AND THE NEW DAY}

we have a good policy? The only effective way is by the organization, under the federal principle, of permanent groups authoritatively representing the different aspects of the farm problem, and the different public and voluntary agencies which are at work or that may come into being. National and state councils are imperative; county and community councils are almost equally important. An international council of agriculture and country life is not beyond the range of possibilities. There is no other method by which American agriculture can be assured its full measure of intelligent improvement and its adjustment to a developing civilization.

\section{A RURAL DEMOCRACY}

In the social reorganization of the world the farmer must have his part. He must not be an underling. In intelligence, freedom, initiative, he must stand as the good citizen. He must participate in political, industrial and social arrangements for the common good of mankind. We do not want and we will not tolerate an agricultural caste out of which it is difficult to rise. The farmer must be truly free and fully respected. An American program of rural reconstruction finds its need then in a wise, united planning for a true democracy in which the farmer himself will find his place in full freedom and in splendid efficiency. 


\section{CHAPTER XIV \\ THE URGE OF THE NEW DAY}

THE great war is over. The menace of autocratic world-power has been ground to powder. The birth pangs of the New Day are gone. The European world, torn and bleeding, wearily faces the task of rebuilding herself into health and strength. The world has been made safe for democracy. But democracy is yet an infant to be nursed into a virile maturity through years and decades of experiment, failure, selfeducation, disappointment, enlargement, reshaping, final triumph.

America emerges from the war potent for aid in the work of world reconstruction. Her resources barely touched, her casualties relatively small, her strength unimpaired, she must shoulder much of the world's burden. She has fought effectively to help save for humanity the freedom she has cherished as her own great ideal; she must now wield her might on behalf of a genuine democracy for all peoples. Nations must learn to be both efficient and free.

Is the farmer ready for the New Day? Shall he reap the full harvest of "greater opportunity and greater prosperity"? Is the American farmer ready, first of all, to do his full share toward feeding the hungry nations until they can care for themselves? Perhaps here is his largest opportunity to help in reconstruction, for as Jane Addams has recently written: "There are unexpected turnings in the paths of moral 


\section{THE FARMER AND THE NEW DAY}

evolution and it would not be without precedent if, when the producing and shipping of food is no longer a commercial enterprise, but had been gradually shifted to a desire to feed the hungry, a new and powerful force in international affairs would have to be reckoned with." Here is a glorious vision of an idealist. But after all is it visionary? Feeding the hungry world is the farmer's task in the New Day. Why should he not recognize it? Why should it not be his great inspiration? This conception of his task and the bending of his will to its fulfillment may have consequences far beyond that of merely appeasing hunger.

Mr. Hoover has gone abroad again; after he went it was announced that there would be a world organization of the food supply. This step is clearly necessary if scores of millions of earth's people are to be kept from starvation. But the idea is profoundly true as a basic need of the New Day. The world will be poorly compensated for its sufferings in the present war if it cannot organize its production and distribution of food so that there is no hunger anywhere.

\section{AMERICA UNPREPARED FOR TIIE NEW DAY}

In many ways we are unprepared for peace. We do not have an agricultural program. There is no responsible institution, no representative organization, no responsible group of men with a program. Most of us look to the Department of Agriculture for leadership and statesmanship in a matter of this sort. We do not find it. Various farmers' bodies have definite ideas on many of the needs of the new time, but there is no representative group of farmers with a comprehensive, clearcut, adequate plan for the improvement of American agriculture and country life. The De- 
partment of the Interior has given publicity to a grandiose scheme for providing land for returning soldiers. Later came the announcement that the Department of Labor would soon announce a solution of that problem. Thus far, the Department of Agriculture has been silent in the matter. Many groups are discussing these problems, secking to outline plans of operations. Thus far, there is no unity among them and there has been no serious effort indeed, to bring them together.

\section{WE SHOULD TAKE TIME TO MAKE A PERMANENT} AGRICULTURAL PROGRAM

A program should be made only after great care and much study and with counsel from many minds and from many points of view. It cannot be made in a day nor by any single man, nor even by a group of men representing only a portion of the forces to be correlated or interested in only a part of the problem.

An agricultural program should be as broad as the whole problem. It cannot be confined merely to production. Indeed, its great emphasis will be upon just distribution, skillful farm management, a satisfying country life. We should frankly discuss such basic questions as acquisition of land, provision for farm labor, relations to other industrial groups.

In order to secure such a broad and well considered plan of improvement, it is necessary that there should be free and constant coöperation among all the individuals and all the organizations which may fairly be said to represent the working farmers, as well as responsible representatives of publicly supported institutions dealing with agricultural affairs.

A beginning should be made now. 


\section{THE FARMER AND THE NEW DAY}

\section{UNIFY AMERICAN AGRICULTURE}

It is wholly impossible for the farmers of America to take their proper place in helping to solve the problems of reconstruction that are confronted at the very threshold of the New Day, unless agriculture can present a single front - a unified purpose and an aggressive program. It is necessary that the two main groups of rural institutions, those supported out of the public treasury, and the private or voluntary associations and organizations of various types should work in closest harmony. There is an imperative call upon the agencies of agricultural education to get together at once not only to map an adequate program of agricultural education, but to take steps to carry it out in the spirit of a large unity. We should have a comprehensive and statesmanlike plan for the utmost development of our rural school system, backed by the farmers and coördinated with our system of agricultural education. There is the same pressing need of real unity and thorough-going coöperation among the various farmers' organizations. The country life interests should be federated. Anything short of this full unification of rural forces will result in a partial program. It will mean failure to meet the great exigency. The fundamental need of the New Day is, therefore:

\section{THE LARGER COÖPERATION}

Much good can be done by partial effort. Groups here and there, individual agencies, studying and planning and working, will accomplish much, but it is only through the cooperation of all interests that the demands of the New Day are to be met. 


\section{THE URGE OF THE NEW DAY 265}

Larger Coöperation Nationally. Under one name or another, what, it does not matter, there must be a conferring group that shall attempt to correlate agricultural forces. Let us call it a National Council of Agriculture and Country Life unless a better name can be found. Let it be thoroughly representative in its makeup. What could it do?

I. It could outline a clear-cut statement of the American farm problem.

2. It could develop a plan for ensuring the comprehensive study and the accurate mapping of the agricultural resources of the entire country.

3. It could make a statement of the main elements in an American agricultural policy that would attempt to secure maximum efficiency on the part of the farmers, a fair labor income for their efforts, and the proper relationships of American agricultural activities to the world's need and supply of food.

4. It could make a program of efforts needed to carry out large policies. It could list the various agencies now at work on behalf of agriculture, show what each is doing and indicate how it may fit into the program. It could recommend improvements, if necessary, in existing agencies and organizations. It could seek constantly to secure the coöperation of all these agencies on behalf of the program.

It may be asked whether such a council should be permanent. It seems to be the only way out. There is a call for a permanent national agricultural general staff, one that is representative of the widest possible range of agencies. It would be inadequate if it represented merely the government or merely the farmers. Unity is indispensable to the most complete agricultural advancement and unity can be gained only by uni- 


\section{THE FARMER AND THE NEW DAY}

fying. This larger national coöperation is therefore indispensable for the New Day.

Larger Coopperation in the State. The same need exists in every state for this getting-together of the agricultural interests - the state board or department of agriculture, the department of education, the agricultural college, the farm bureaus, the Grange, the Farmers' Union and all other voluntary organizations. It would be well if in each state there could be the equivalent of an agricultural development committee composed of the official representatives of all state-supported agencies charged with work on behalf of agriculture, to outline plans for studying and mapping the agricultural resources of the state, make a program for the development of agriculture and country life and suggest methods of securing the coöperation of the various agencies. Beyond this, there should be a federation of rural agencies, to include not only the public institutions, but the voluntary associations of farmers and others interested in rural affairs.

Larger Coöperation in the Community. No other form of effort to organize agriculture and to make it efficient will reach its full power, unless in every one of the 50,000 possible rural communities we have the people working together and thinking together and talking together and planning together and acting together, for every common purpose of their common need and for a common contribution to state, national and world welfare.

Larger Coöperation in the County. County councils of agriculture and country life might well be instigated by the county farm bureaus, but should not be subordinate to them; for the farm bureau is only one of many agencies in most counties. But wherever the county 
is a prominent feature of American political life, this larger coöperation of county activities is necessary.

Larger Coöperation between City and Country. We have made scarcely a beginning in bringing together city and country. The need is felt particularly in the relations of the small country city or county seat situated in a farming region. It is mischievous to permit the continuance of those antagonisms that do prevail. In the New Day there is no place for sharp class distinctions. The larger coöperation must involve all interests, all classes, all peoples.

The $W$ orld as a Field for the Larger Coöperation. There are those who have been pleading for some while that not only American agriculture, but world agriculture, must be thoroughly organized. The war has forced this problem upon us whether we will or no. We can no longer remain immune to what European countries or South American countries or Asiatic countries are doing in agriculture. The International Institute of Agriculture in Rome was a sincere and farsighted effort to provide a clearing-house for world agricultural interests. Why not use it as the nucleus of comprehensive world organization for agriculture?

We must not devote our energies and thought wholly to the business or economic side of agriculture. The great human interests of farmers as a class and as a part of the world democracy must be taken into consideration. Before the war there were the beginnings of a very distinct call for agricultural missionaries to go into backward agricultural countries like Turkey and India. The result of this war ought to be the organization of a world agricultural mission. The countries that will emerge from the war well organized, forwardlooking, competent, should pool their agricultural in- 


\section{THE FARMER AND THE NEW DAY}

telligence and skill on behalf of the human as well as the economic interests of the peasants of Russia, the rural villages of India, and the tiny farms of China. America particularly ought to be open to an appeal for a world program of agricultural education and country life propaganda that will supplement coördinated agricultural business and economic interests.

Sooner or later there will have to be due recognition of world interest and world solidarity in regard to rural affairs. The very moment has arrived to recognize that interest in an international conference and presumably in some form of permanent council or conferring group. The desirability has long existed. It has now become imperative.

\section{THE FIRST STEPS}

In reconstruction plans, probably agriculture will be recognized. A national commission to study these problems may be necessary and desirable, but we cannot wait for that. The most important single step that can be taken is to secure a thoroughly responsible national conference to consider the agricultural program of reconstruction. Ideally, this would be called by the Department of Agriculture; but at any rate it ought to be brought together and in the immediate future. There is no other way of mapping an adequate policy for securing a working program.

There could be formed at least a temporary National Council of Agriculture and Country Life, composed of representatives from such bodies as the National Grange, the National Board of Farmers' Organizations, the Advisory Committee to the Secretary of Agriculture and the Federal Food Idministration, the American National Live Stock Association, the Na- 
tional Grain Growers' Association and possibly other similar groups; and among the publicly supported agencies, representatives from the United States Department of Agriculture; the Federal Food Administration; the Association of American Agricultural Colleges and Experiment Stations, and such groups as the Association of Agricultural Economists, the Association for Agricultural Legislation and the State Marketing Officials.

\section{THE HOUR HAS STRUCK}

America was unprepared for war. She is unprepared for peace. She carried the war to a glorious end. She will be equal to the demands of peace. But there is no time to lose. We did not have an adequate agricultural program before the war. We did not develop one during the war, and we do not have one now. But we are completely competent to make such a program. There are hosts of men who see the need, who have the vision, who possess knowledge and ideas. These men are to be found among the farmers and among public officials, but their knowledge, their ideas, their vision, their efforts must be correlated. It is only so that we can meet the issue of the hour. The urge of the New Day in agriculture is a definite policy, an adequate program, and the larger coöperation.

Europe cannot be rehabilitated unless its agriculture is rebuilt. Are the American farmers ready to help in this rebuilding? The New Day will be merely a dream unless the farmer as well as the laborer comes to his own. Education and organization now and evermore are the only doors through which the farmer can pass to his rightful place. 



\section{APPENDIX I \\ THE FORUM AND THE COMMUNITY ${ }^{1}$}

The rise of the community is one of the outstanding social phenomena of our time, not yet generally discerned, much less accepted as a working basis of social reconstruction.

\section{THE FIRST COMMUNITY ORGANIZATION}

The forum is the first distinctively community organization emerging out of the reconstructive chaos through which yesterday is becoming to-morrow. Isms no longer cohere; sectarianism is a spent force; dogma is dead; and the caste castles of yesterday are everywhere capitulating to democracy. Society is being reconstructed in terms of human essentials, and in many instances the forum has already become not only humanizing but human.

\section{A COMMUNITY CRUCIBLE}

Because of this, the forum is a community crucible, in which Jew and Gentile have offensive Judaism and defensive Gentility burned away; in which the ignorantly bound are made intelligently free, and the coldly free are warmed to communicy service.

\section{A COMMUNITY SCHOOL}

These things happen because the forum is a community school. Educated people are beginning to be socially intelligent, or at least to understand that social ignorance is the unpardonable sin against the Holy Spirit that indwells in all life as well as over-broods it. In the forum, knowledge is in-

${ }^{1}$ By Harold Marshall, of the Community Forum Movement. 


\section{THE FARMER AND THE NEW DAY}

structed by wisdom, and often the broken English and halting thought of a question from the floor is greater than many flowing periods from the platform. Not every audience learns anything from every speaker; but any speaker can learn much from the collective wisdom of any audience.

\section{AN INTERPRETER'S HOUSE}

In this wise, the forum becomes an Interpreter's House, where each finds his own problems solved by the common experience, his own questions answered by the collective wisdom, and above all where he learns that which saves evolution from revolution - that these problems are not new, only new to him; that others have asked and found at least partial answers that help him to larger answers; that he is bruised with the unconquered hardships of a brutal and savage past; and that he cannot be healed by any self-sought balm, but only by the oil of common sacrifice.

\section{AN EXPRESSION OF HUMAN RELIGION}

In the forum the still inarticulate religion of humanity is beginning to find a voice. Some forums had orthodox beginnings, but soon lost them. Many possessed an early piety, but outgrew it as soon as they began to grow at all. But all real forums become increasingiy religious, not by intention, but because every human being, stripped of orthodoxy and piety, reveals a naked soul. Many a preacher, heartsick from the Phariseeism of the pew, has been healed by the publican of the forum. Indeed, to many outcast souls the forum is a half-way house from Churchianity to Christianity.

\section{A QUICKENER OF THE COMMUNITY CONSCIENCE}

Every forum is a quickener of the community conscience. The ethics of Christianity have been individualized through ages of individual effort to escape from a hellward-bound society to a selfish heaven. The supreme ethical problem of our time is to re-state the social principles of the Hebrew prophets, 
that found their latest and greatest social statement in the supreme Prophet of Nazareth, so that the individual conscience shall function in social terms. The forum is doing this in many communities, and for a rapidly increasing number of individuals. Its greatest actual achievement so far is the number of social sinners it has converted into social servants.

\section{A COMMUNITY CHURCH}

In what has already been said is implied what may yet be the greatest of all the contributions of the forum to the community life of to-morrow. It is increasingly apparent to all thoughtful people that one of the great problems of our time is the reintegration of divisive and competitive and mutually limiting sectarian organizations into a new religious unity. The forums are making a distinct and increasing contribution to the solution of this problem. The working creed of the Open Forum is " the belief that we must all move together toward the solution of the successive problems of mankind through the dedication of each to all, the devotion of all to each, and our common consecration to all the nobler ends of life." Its spirit is the modern spirit that has changed religious emphasis from other-world individualism to the increasingly heroic endeavor to bring in the Kingdom of God among men. It is inspired by the religion of the common life; it may yet prove a powerful help in the development of the church of the common life. 


\section{APPENDIX II}

\section{WHAT SOME COMMUNITIES ARE DOING}

All over the country there is an increasing tendency to take up rural affairs on a community basis. It is almost impossible to classify these because most of them are not given publicity in any wide way, but there is no doubt that the community method of doing business is growing. Merely for the purpose of illustrating the variety of community effort, there is appended a statement of what some Massachusetts communities are doing. These are to be found in a recent bulletin from the Massachusetts Agricultural College, entitled, "Mobilizing the Rural Community," and written by Professor E. L. Morgan, Community Adviser at the college. These are actual instances of efforts and can be verified.

\section{WHAT SOME COMMUNITIES ARE DOING ${ }^{1}$}

\section{IN FARM PRODUCTION}

The organization of a livestock improvement association that has brought 135 pure-breds into the herds of one town in three years.

Poultry producers have brought about the adoption of one breed of poultry for one town.

Through a soil improvement club one town has increased crop yields.

The organization of a cow test association that has weeded out 4I unprofitable cows from the herds of one town.

A large number of towns have stimulated agricultural improvement through coöperation with the farm bureau.

1 Anyone interested in any item here mentioned may, upon request, get the name of the town in which it is being carried out. 
Last year one town increased its acreage of potatoes $92 \%$, another its acreage of beans $200 \%$ and another its acreage of corn $160 \%$.

An all-winter lecture service on agriculture and home making was secured in one town from the farm bureau.

\section{IN FARM BUSINESS}

Some thirty farmers' coöperative exchanges have taken over much of the purchasing of farm supplies in as many towns. In some ten towns farmers got together through the farmers' exchange, adopted a brand, and have had their products packed by one man for the last three years.

Thirty-one farmers are keeping farm accounts and are thereby learning their business.

By forming a local farm loan association farmers in a number of towns have been able to get better long-term credit facilities.

Special short-term loans for crop production were secured for sixteen farmers in one community.

Farmers in one section have combined in establishing a milk processing and distributing system.

Last year business men of one section furnished seed potatoes, fertilizer, and spray material, the farmers the land and labor. The crop was divided equally in the field.

Last year 48 towns established community markets where the surplus farm and garden products were easily disposed of. A group of farmers in one town have combined and are using a motor truck in delivering their farm products.

Farmers in a number of sections have financed the gathering and circulation of market news information.

\section{IN CONSERVATION}

Community canning and drying centers were established. Food thrift conferences and demonstrations were held.

Women in many towns have met regularly for the study of foods and their conservation.

Substitutes were used for staples in feeds and fuels. 


\section{THE FARMER AND THE NEW DAY}

A plan was outlined for developing and conserving natural resources.

Points of scenic and historical value were purchased and improved.

\section{IN BOYS' AND GIRLS' ACTIVITIES}

Last year $75 \%$ of the towns and cities of the state encouraged hoys' and girls' club work and appropriated funds to employ a local club supervisor for the summer months.

Several towns have opened a community center in the school building or elsewhere which is of great educational value to its young people.

One town took a church census which showed church and Sunday School attendance among boys and girls.

Boy Scout and Camp Fire Girl and Y. M. C. A. work are established activities in many communities.

One town is running the moving picture business at cost. This gives a carefully selected program at a low price.

A recreation field was purchased by one town which gave a public place for baseball, basketball, picnics, etc.

\section{IN COMMUNITY LIFE}

\section{a. In General Community Affairs}

A number of towns, using the community council scheme, have worked out a thorough long-term plan of development by means of which they are getting results.

A uniform plan of organization for special war work has reached every town in the commonwealth.

This year 300 towns were officially represented at the community leaders' planning conferences, one of which was held in every county of the state.

Two hundred and eighty-six towns have held special community conferences to consider development plans for 1918.

\section{b. In Horne Affairs}

Home making study in women's clubs has encouraged interest in home affairs. 
Home making taught in the schools has given girls a new attitude toward the home and its work.

A home planning exhibit in the library brought out much interest in house arrangements. Five homes were built from these plans.

The town housing act was adopted by many towns, thus safeguarding the town against dangerous and unhealthy houses. Home making lectures and demonstrations have developed interest in home affairs in many towns of the state.

Extension schools in home making have been held in a number of communities through coöperation between the Agricultural College and the farm bureaus.

\section{c. In Education}

A sub-library has been placed in every school in the town, thus making books available to the children.

Some 150 towns made an appropriation of $\$ 100$ to $\$ 200$ for a boys' and girls' club supervisor which resulted in large numbers of boys and girls doing club work last year.

A town Christmas tree was participated in by all churches and many other organizations.

A town agricultural fair association holds an annual fair and exhibit of things made or grown in the town.

A parent-teacher association has developed a spirit of perfect coöperation on school matters.

An Agricultural College extension school resulted in a thorough study of the agricultural situation in one town. Plans were made and good results obtained.

A community progress conference was the starting point for a general community organization plan in one town.

Vocational teaching has been the means of holding many boys and girls in school as well as given them vocational guidance.

In some 25 towns attention has been given to noonday lunches.

A public forum gives the people of one town an opportunity to discuss the live questions of the day. 


\section{THE FARMER AND THE NEW DAY}

The organization of a community house has given a social center for the people of one town.

The Agricultural College correspondence courses in poultry, pomology, home making, etc., have been taken by a large number every year.

Lectures and demonstrations in home making, orcharding, poultry, marketing, public health, etc., have stirred one town to the point of planning for the future.

\section{d. In Public Health}

A pure and abundant water supply made one town healthier and gave adequate fire protection.

A number of towns maintain district nurses. In some of these the funds are appropriated at the annual town meeting.

A sewage disposal system reduced many forms of disease and generally improved the health of the people.

The town housing plan was adopted and made impossible the building of dark or poorly ventilated houses.

The eradication of flies and mosquitoes was brought about through a public health survey which showed breeding places and suggested remedies.

A town clean-up day really cleaned up the town, many loads of refuse being gathered at town expense.

\section{e. In Transportation and Communication}

Road construction according to a permanent improvement plan has saved several hundred dollars every year and given much better roads.

A steam roller for road building and maintenance has proven more economical than teams for drawing the road machine and packing the surface.

A new trolley schedule adapted to the needs of the town has been inaugurated.

Trolley express facilities have been increased so that the farmer was brought into much better communication with his market. 
Sidewalk improvement and extension did much for the convenience of the people and the improvement of one town.

A new road system resulted in opening new roads and abandoning others. This was a great help to the farmer in reaching his market.

The use of a split log drag finally won its way and resulted in better roads at less expense.

\section{f. In Recreation}

A recreation field gave the young people a permanent place for plays and games. The whole town uses it for picnics, festivals, etc.

An annual recreation field day or a sort of old home day has done much to develop community interest.

Monthly public entertainments of real value have been given instead of haphazard events.

Local dramatics have helped to hold the interest of young people. Play apparatus in schools greatly reduced the problem of playground discipline and gave incentive and purpose to play activities.

Organized athletics, baseball and basketball, held the loyalty of both boys and girls to other things in the town.

A July 4th celebration did much to develop the patriotic motive. It dealt with local historical events. The people remained at home and enjoyed a quiet though impressive day.

A May day celebration enlisted the children of the schools in an event which they felt was their own.

\section{g. In Civic Affairs}

The improvement of public property has increased the civic pride so that many homes are being improved through planting.

Through the removal of bill boards one town got rid of unwholesome pictures which were constantly before their children. 


\section{THE FARMER AND THE NEW DAY}

A home improvement contest enrolled 31 homes and resulted in very marked improvement in all of them.

Many towns have planned and improved the school grounds, cemeteries and playgrounds.

The placing of guide boards has very materially improved the facilities of travel in one town.

Grounds of scenic and historical value were purchased which would soon have been appropriated for commercial purposes.

A town finance committee was organized which has given study and direction to the financial affairs.

A town planning board worked out a plan for public buildings, streets and parks.

An annual tree planting day gives one town more trees in public places each year.

Roadside care and planting has made many highways more beautiful and easier to take care of.

\section{h. In Public Morality}

A religious education plan whereby every child was given religious education by some church.

An anti-saloon and vice crusade was carried on. This was a combined community and church movement that secured results.

Lectures on subjects pertaining to special phases of public morality have resulted in a new standard of living for one locality.

A church membership survey of the town showed the exact constituency of each church.

A church federation united the two churches under one minister, each church still retaining its identity and organization. Church coöperation in social service combined the work of all into an all-year-round social service plan. The county $\mathrm{Y}$. M. C. A. was a large factor in bringing this about. Supervision of dance halls and moving picture shows eliminated the undesirable features and made them of real value to the town. 


\section{APPENDIX III}

\section{PROGRAM FOR FOOD PRODUCTION AND CONSERVATION}

\section{THE FARMER'S RESPONSIBILITY}

Upon the farmer rests in large measure the final responsibility of winning the war in which we are now involved. The importance to the nation of an adequate food supply, especially for the present year, can not be over-emphasized. The world's food reserve is very low. Not only our own consumers, but much of the world at large, must rely more completely than ever before upon the American farmer. Therefore, the man who tills the soil and supports the soldier in the field and the family at home, is rendering as noble and patriotic a service as is the man who bears the brunt of battle.

The American farmer has long shown his ability to produce more food per man and at lower cost per unit than any other farmer in the world, but he has never had to do his best. He needs to do his best now. This is not the time to experiment with new and untried crops and processes. It is very important that the farmer devote his principal efforts to the production of such crops and the employment of such methods as are well established in his community and as are likely to yield the maximum return in food and clothing material.

Within the next sixty days the final measure of crop acreage and food production for this year will have been established. We urge the importance of the immediate mobilization of all available service of the federal and state Departments of Agriculture and the colleges of agriculture in coöperation with the press, the banks, the commercial organizations, the religious and the social societies, that all may heartily join with the farmer in performing the patriotic duty of providing and conserving food. 


\section{THE FARMER AND THE NEW DAY}

Because of the world shortage of food, it is scarcely possible that the production of staple crops by the farmers of the United States can be too great this year. There is every reason to believe that a generous price will be paid for the harvest of their fields.

\section{INCREASING THE FOOD SUPPLY}

There is yet time to add substantially to the bread supply by increasing the acreage of spring wheat in the northern states. Throughout the United States, east of the one hundredth meridian, the corn area may be increased to advantage, with a view to its use both for human food and animal production.

The production of a normal cotton crop is necessary. This can best be accomplished by more intensive cultivation and increased fertilization rather than by increasing the acreage and thus neglecting the food and forage crops so important to the south.

In the districts where wheat has been winter killed replanting is suggested with oats, corn, or sorghum, as climatic conditions may determine. Where barley and oats are proved and reliable crops, they should be planted to the maximum that can be effectively handled. In portions of the northern and eastern states, where the season is too short for the great staple crops, the buckwheat acreage may well be increased.

An important increase in our food supply may be made by enlarging the area planted to navy beans in the north and west and to Mexican and Tepary beans in the southwest, and by stimulating in every reasonable way an increase in the area of potatoes planted, especially for local use.

Sweet potatoes in the south will undoubtedly be needed in their fresh state in larger quantity than usual and also for storing for winter use either in their natural state or as canned or desiccated products. Where peanuts succeed, production may well be enlarged because of their value both as food and forage.

A reasonable seed reserve for replanting tilled crops should be held wherever practicable.

While it is important to utilize available lands in the staple 
small grains and tilled crops, care should be taken to avoid undue encroachment on the area used for pasturage or hay which is required for live-stock production.

Authority should be granted the Secretary of Agriculture to advance to farmers under proper safeguards seeds required to insure the production of crops decided to be necessary for the welfare of the nation.

\section{THE SCHOOL CHILDREN'S PART}

We appeal to the youth of the nation to put forth every effort to produce foodstuffs in gardens and fields. There could be no better expression of true patriotic devotion to the country. It has been demonstrated through the boys' and girls' clubs that it is possible for the farm family to supply itself with much of the food required, thereby releasing the commercial product of the country for the needs of the neople in the cities and in foreign lands.

In a normal season it is certain that there will be large quantities of perishable products which can not be properly preserved in the home. To meet this emergency it is recommended that local and municipal drying and canning establishments be improvised to conserve this material.

\section{KEEPING UP THE MEAT SUPPLY}

The live-stock holdings of the farmers of the United States are already too low. It would be most unfortunate if these numbers were diminished further under the pressure of the present demand for food. Indeed, an early increase of the animal products of the country should be made. Such an increase must come chienfy through the enlarging of our feed supply by more successful methods of feeding, and through more complete control of contagious diseases.

Milk production could be increased fully one-fourth by more liberal and intelligent feeding. Pork production could be increased substantially through the more extensive use of fall litters, better care, and feeding. The poultry products of the United States could be doubled within a year. 


\section{THE FARMER AND THE NEW DAY}

Contagious diseases of farm animals take a toll of more than a quarter of a billion dollars annually. More than half of this loss is due to controllable diseases, such as hog cholera, black-leg and Texas fever. The federal government, coöperating with the states, could profitably expand its intensive regulatory services so as to embrace every important live-stock district in this country.

\section{MOBILIZING FARM LABOR}

One of the principal limiting elements of food production is the labor supply on the farm. Indiscriminate enlistment from the farms with no plan for labor replacement will reduce food production below its present low level.

The plan for public defense should include as definite a program for enlistment for food supply as for service at the front.

In addition to more than one-half of those applying for enlistment and rejected because of unfitness for military service, there are more than two millions of boys between the ages of I 5 and 19 years in the cities and towns not now engaged in productive work vital to the nation in the present war emergency. These constitute the most important hitherto unorganized and unutilized labor resources available for this emergency.

In consideration of all these facts the plan of military enlistment should be broadened so as to include in a national service those who, by reason of their age or physical condition, are permanently or temporarily incapacitated for active military duty but who are able to render to the government equally indispensable service in the production of food, supplies and munitions.

This enlistment should include three classes: Men beyond military age; men of military age but not accepted for active military duty; and boys under age for enlistment.

The government should make plans at once for the mobilization of this important resource for the production of food and 
other necessities. This proposed enlistment in the national service should be regarded as part of the public patriotic service in the present war emergency and be given proper official recognition.

\section{THE HARVEST EMERGENCY}

The husbanding of a matured crop promptly is often the most vital and crucial point in production and is the point of the heaviest labor demand on the farm. We suggest that the federal Department of Agriculture, coöperating with the state departments of agriculture and other agencies, should take steps to mobilize farm labor to meet all emergencies which may arise.

\section{A SURVEY OF THE FOOD SUPPLY}

We suggest the importance of a thorough-going survey of the food, labor, and other resources of the country and of the needs of the local communities to the end that every part of the country may be maintained in effective service. Therefore, we recommend:

That power be conferred upon the Secretary of Agriculture, in coöperation with the Federal Trade Commission so far as practicable, to secure such information regarding the food supply of the nation and all business enterprises relating thereto as may be necessary to enable Congress to legislate suitably for the protection of the people in the existing crisis and for the information of the nation in its daily conduct, giving to the Secretary of Agriculture for this purpose power to administer oaths, to examine witnesses, and to call for the production of books and papers with means of enforcement and penalties.

That authority be conferred upon the Secretary of Agriculture to establish market grades and classes of farm products, including seeds, and standards for receptacles for such products. For this purpose he should consult the various trades concerned. The established grades for corn and wheat undoubtedly will be of much advantage in purchasing supplies and the establishment of grades for other products will be fully justified for the same 


\section{THE FARMER AND THE NEW DAY}

purpose. Furthermore, such standards, with a suitable degree of supervision of their application, will result in returning to the producer the value of the particular qualities he produces, thus encouraging adequate production in the future. 'This is of special importance in connection with the perishable crops, but applies with almost equal force to the staples.

The Secretary of Agriculture should be authorized by law to license warehouses, packing plants, mills, cold storages, produce exchanges, coöperative and other shipping associations, commission merchants, auctioncers, brokers, jobbers, wholesale distributors, and other individuals, partnerships, associations, and corporations engaged in the business of marketing and distributing farm and food products. When directed by the President, the Secretary should have power, after advising with the Council of National Defense as to the necessity of such a step, to take over and operate such of these businesses as may be warranted, in a manner similar to receivership.

In order to facilitate the solution of transportation problems, government agencies should do all in their power to bring about a relatively adequate supply of cars for moving food and other necessities.

Communities, counties, and cities should be urged to take steps that will lead toward a larger degree of local and district self-support, especially in perishable products, by making inventories of food needs and surveys of neighboring possibilities of production and in general by closer coöperation of the local consuming and producing interests and by the provision of local marketing facilities.

\section{PRICE PUBLICITY}

To bring about a greater equality of distribution considering the consumptive demands of population centers, the market information facilities of the United States Department of Agriculture and the several state departments should be extended and made as effective as possible. It should include the publishing, as widely as possible for the information of producers and consumers of farm products, of average prices of foods, feeds. 
and live stock, and particularly those paid by the War Department, if purchases are made direct in the open market instead of by the usual contract method.

If not incompatible with wise policy, the War Department should determine and state where training camps are to be located, so that local production can be expanded to care in some degree for the increased consumption as a measure of general economy, and to effect a further relief of transportation facilities.

Appropriate steps should be taken through suitable federal authorities such as the Council of National Defense, the Department of Agriculture, the Department of Commerce, and the Federal Trade Commission, to facilitate the supplying of agricultural implements and machinery, particularly for seeding and harvesting, by bringing about reasonable deliveries of the necessary materials, in preference to filling orders for such products as are not required in the existing emergency.

Steps should be taken at once to secure the preference movement of freight shipments of farm machinery, seeds, fertilizers, and spraying materials.

\section{PRICE FLXING, IF NECESSARY}

The very low food reserves of the world, due to last year's short crops, the increased demands due to the consumption and waste of war and the disappointing condition of the winter grain crop give ample assurance of profitable prices to producers this year. Therefore, the fixing of maximum or minimum prices need not be undertaken at this time, but the fact that such a course may become necessary in the future advises the creation of agencies which will enable the government to act wisely when the necessity may arise. To this end, it would be well for the Congress of the United States to authorize the Council of National Defense, if deemed necessary, to purchase, store, and subsequently distribute food products, or to fix prices in any national emergency caused by a temporary or local overproduction or by a sudden ending of the war or by restraints of trade, manipulations or uneconomic speculation, in order that 


\section{THE FARMER AND THE NEW DAY}

producers may not be required to suffer loss on account of the extraordinary efforts they are now asked to make, and in order that consumers may not be required to pay oppressive prices in case of disorganized or inadequate transportation. Information shouid be continually maintained by the Department of Agriculture that will afford the council intelligent data upon which to act wisely and fairly in any emergency.

\section{INCREASED HOME ECONOMY}

We are the most wasteful people in the world in our ways of living. Our tastes and desires have been educated beyond our incomes.

Almost as great a saving may be made through the more economical manufacture, purchase, and use of food as can be made through processes of production which are immediately feasible.

Our breadstuffs supply may be increased by one-twelfth, or $18,000,000$ barrels of flour a year, by milling our wheat so as to make $8 \mathrm{I}$ per cent. of the kernel into flour, instead of 73 per cent. as at present. This flour would have as high nutritive value as that which we now use.

An important saving may be effected by making the diet as largely vegetarian as possible, without lowering food efficiency, by a partial substitution of such foods as beans and peas and of milk and its products, including skimmed milk, for the more expensive meats. At present prices a larger use of corn and rice products as partial substitutes for the more expensive wheat products is suggested.

The substitution of the home-grown and home prepared grain products for the much more expensive refined commercial foods, known as breakfast foods, will make a large saving. Adequate gardens should provide the home supply of vegetables, which are expensive foods when purchased at existing prices. The home storage and preservation of foods, such as eggs, vegetables, fruits, and meats, should be increased. The serious food wastes that occur in many households through a lack of culinary knowledge and skill may be minimized through instruction in better methods. 
These economies will be secured chiefly, if not fully, through the further education of housewives. It is highly important that all educational agencies available for this purpose engage in widespread propaganda and instruction concerning the economical use of human foods.

\section{NATIONAL AND STATE ORGANIZATION NEEDED}

The Council of National Defense is charged with the duty of mobilizing the resources of the nation, having as one of its members the Secretary of Agriculture. We recommend additional machinery as follows:

A relatively small central agricultural body, whose services and presence might be required in Washington constantly, to be composed of men who have wide knowledge of agricultural matters and executive experience. In selecting these men, attention should be paid to geographical distribution.

A large national advisory body composed of representatives of the leading agricultural agencies and associations concerned not only in production but in distributing and handling commodities.

A small central agricultural body in each state representing various agricultural interests, including agricultural officials, representatives of agricultural colleges, bankers' business, farmers' and women's organizations, etc., concerned in the production, distribution, and utilization of food supplies and agricultural raw materials. This body should be designated by the governor and, if the state has a central council of safety or defense, should be coördinated with it.

Such county, urban, and other local bodies as the state authorities, including this state central agency, may see fit to suggest.

The national central body and the state central bodies will be expected to keep in intimate contact and to work in close coöperation.

\section{AN EMERGENCY APPROPRIATION}

To meet the extraordinary needs of agriculture in this emergency we recommend an appropriation of $\$ 25,000,000$, or so 


\section{THE FARMER AND THE NEW DAY}

much thereof as may be needed, to be available immediately for the use of the Secretary of Agriculture in such manner as he may deem best.

The situation which now confronts our country is a great emergency - the greatest, perhaps, in its history. Emergency measures are needed to meet unusual conditions. The recommendations made in this statement have been formulated because it is believed that they are necessary in order to meet present conditions. They are war measures. It is strongly urged that Congress and state legislatures, in passing laws or in making appropriations intended to carry out these or other plans for assuring an adequate food and clothing supply, should, so far as possible, be governed by the principle that when the emergency ceases much permanent reconstruction in agricultural policies and plans may be necessary.

The recommendations in the main call for federal action, but state governments can and should coöperate to the fullest degree in considering and executing plans of coöperation for the great common purpose herein enunciated.

(From the Program for Fond Production and Conservation, prepared at the conference of the Secretary of Agriculture and representatives from 32 states, held at St. Louis, Mo., April 9-10, 1917.) 


\section{APPENDIX IV}

\section{AN AMERICAN AGRICULTURAL POLICY}

The following note, prepared by Dr. Alexander E. Cance, Massachusetts Agricultural College, summarizes the opinions or convictions of sixty or more agricultural leaders - commissioners of agriculture, presidents and deans of agricultural colleges and directors of experiment stations, economists, farmers, prominent leaders in farmers' organizations, bankers, rural journalists and others. In some capacity every man is vitally interested in the agricultural industry. Several are acknowledged national leaders in rural affairs.

To this group of men four questions were addressed:

(I) Has the time arrived to begin the formulation of an American agricultural policy?

(2) Is it feasible and desirable to relate such a policy to the larger questions of the world food supply?

(3) What are the main items which should be included in such a policy?

(4) How can such a policy best be formulated and all agricultural agencies rallied to its execution?

Most of the replies indicated a sincere desire to consider the question seriously and thoughtfully. Very few who replied failed to understand the purport of the questions and all accepted them in good faith. Of the whole number only one or two seemed puzzled and failed to grasp theil full significance. On the whole the replies may well be accepted as typifying the best thought of the day on the agricultural problem.

I. HAS THE TIME ARRIVED TO BEGIN THE FORMULATION OF AN AMERICAN AGRICULTURAL POLICY?

It is very sisnificant that the response to the first question is almost unanimously afirmative. With two or three excep- 


\section{2 \\ THE FARMER AND THE NEW DAY}

tions they believe the time ripe for the formulation of an agricultural policy. Several are sure the hour is long overdue. Not a few lave been mulling over or working on the details of such a problem for years.

The reasons advanced for bringing forward the matter now are various. But in the main they are to be found in the agriculcural status brought about by the war. Several men call attention to the fact that the formulation of an agricultural policy is imperative because food production problems are receiving more attention than ever before in the history of the country; because the Fond Administration, the War Industries Board and the United States Department of Agriculture have called the attention of all the people to the underlying principles in the formulation of such a policy; because we have had two fruitful years to study the problem; because for the first time in the history of our country farm production has become a national if not an international concern; because agriculturists as well as statesmen at this time are more open-minded concerning agriculture than ever before; others find in the necessary reconstruction of agriculture and industry after the war, particularly with reference to land settlement and the employment of returning soldiers, a sufficient reason for giving their careful present thought to the formulation of such a policy. Moreover agriculture has now become stabilized because we are beginning to reap the unfortunate harvest of mistakes made in our land policy and agricultural practice of the past; because the soil is being rapidly depleted by exports of fertility in the shape of raw products to other lands; because agriculture is every day becoming commercialized, is in fact no longer a self-sufficing industry; because of the advent of machinery, notably tractors and electrical devices; because the selection of the best men and women in our rural population, owing to the competition of cities, is depriving agriculture of much needed leadership are further reasons for the prompt undertaking of an agricultural policy.

A few men significantly point out the fact that while it is possible to lay down the principles underlying an agricultural pol- 
icy the actual determination of an agricultural program must wait on international politics following peace; in fact it is very likely that America's agricultural policy will be determined in a large degree by economic relations between nations. If economic barriers are broken down and peace is made on a basis of internationalism rather than nationalism, if trade is free between nations, our agricultural policy will be much different than if we continue to maintain our politics on national lines and develop in America a self-sufficing trade policy. Then we will raise corn in Illinois rather than in Argentine and perhaps find it advisable to buy our meat in Iowa rather than in South America.

It is evident that agricultural leaders view the problem in different lights but with almost absolute unanimity find it immediate and pressing, and all believe that the formulation of such a policy will be a great stroke of agricultural statesmanship.

\section{IS IT FEASIBLE AND DESIRABLE TO RELATE SUCH A POLICY}

TO THE LARGER QUESTIONS OF THE WORLD FOOD SUPPLY?

This question was answered very uniformly in the affirmative, although a number of men did not grasp the full significance of the question and saw in it only a question of providing food for people in other parts of the world. It is evident, however, that a sound agricultural policy cannot leave out of account political and productive conditions in other nations. Our agricultural policy, for example, must be closely tied up with that of Canada. With perfect free trade between Canada and the United States our agricultural policy must be quite different from a policy based on high protective duties between two countries. If the United States is to become a manufacturing rather than an agricultural nation an agricultural program will have to be shaped to that end and will have to take into consideration the purchase of many agricultural raw materials produced in other parts of the world. In fact, American agriculture has nearly always been shaped to a greater or less degree by our international trade policy. After the war this will be more true than ever. Our very close affiliations with the allied 


\section{THE FARMER AND THE NEW DAY}

countries will make it imperative that we take into account their commercial well being. Certain of their products, which they can produce well and more cheaply than we, will under free trade conditions be shipped to us. On the other hand we shall produce those commodities for which we are naturally best fitted, thus making the best use of the natural resources of the world without regard to the flag which floats over them. Hereafter we must think in international terms.

III. WHAT ARE THE MAIN ITEMS WHICH SHOULD BE INCLUDED IN SUCH A POLICY?

When it comes to a statement of the main items which should be included in an agricultural policy it is very evident that agricultural leaders have great difficulty in separating the essential from the non-essential. A host of items were mentioned, some of them patently reflecting local conditions, some of them the pet themes of the writers, some of them obvious agricultural needs and others including a comprehensive national program. Altogether a catalog of these items, as gleaned from the replies, comprehends almost every phase of the agricultural program and represents nearly every part of the country. A rather rough analysis would throw most of the suggestions into a few comprehensive groups.

1. Land problems, including the colonization, settlement, tenure and financing of land.

2. Soil conservation, including not only staying the ravages of erosion and soil depletion by careless farming, but also the conservation of potash, nitrogen, phosphoric acid, lime and other elements or materials of fertility suitable for plant growth in the air, in the soil and in the earth.

3. Control of farm capital, including access to capital for the purchase of land and other permanent improvements, for the purchase of suitable equipment and for conducting current agricultural operations. There is a general feeling that the government has not gone far enough in financial assistance, that while the land banks are good they should be supplemented with institutions for providing short time credit and should be closely 
tied up with agents or organizations who can inspect and advise with regard to the best use of capital. Correlative with this is the problem of supervising the manufacture, distribution and sale of agricultural machinery, and perhaps fertilizers, used by farmers, to the end of its economic utilization.

4. Farm labor, including supply, distribution and condition of employment.

5. Marketing and distribution of farm products, including the organization of farmers for business purposes. Perhaps no items of policy, other than land problems, were more frequently mentioned by these agricultural leaders than the marketing of farm products and the organization of farmers. The following is prevalent, that there are large wastes in the distribution of farm products which it is possible to remedy by an intelligent agricultural policy, either through government assistance or through farmers' organizations or through both. These problems include transportation, both by highway and by railroad, wholesale distribution, storage and warehousing, primary manufacturing, and regulation of commissions and trade practices in the handling of agricultural products and agricultural supplies.

6. Farm life, including conditions in and surrounding the farm home, and community life and surroundings. It is felt that no agricultural programs have sufficiently taken account of the farm home, its construction, sanitation, economic appliances and situation as a part of the farm enterprise as well as a unit in community life.

7. Community life, including education, religion and recreation. Not very much that is definite was advanced on this topic but strong statements were made with regard to the necessity of better rural school conditions and a more wholesome rural community life, at least sufficient to place the country boy and girl as well as the country adult on the same plane with city dwellers. There is a strong conviction that country children in few parts of the country are receiving the same advantages of education that city children of the same economic class are receiving. The country church was emphasized many times as being an essential factor in our rural policy. Moreover the 


\section{THE FARMER AND THE NEW DAY}

rural church problem is apparently as far from solution as ever.

8. A definition of the relation of the government to various agricultural agencies, institutions, practices and conditions. It was strongly emphasized that any agricultural policy should define in no uncertain terms the part which the government should play, not only in the formulation but in the execution of an agricultural policy and the attitude which the federal government as well as state governments should take on various matters. Some of these are:

(a) Land sale, settlement, colonization and tenure. In this connection few men failed to point out the necessity of dealing immediately with the problem of the distribution of land to returning soldiers, first as to the advisability of such distribution, second as to the methods, third as to the conditions, fourth as to financing settlement and settlers.

(b) With regard to political representation in state and nation.

(c) With the organization of farmers, especially for economic purposes but also for social and political objects.

(d) With regard to prices, trade and commercial practices in the distribution of farm products.

(e) With regard to taxation of land and farm equipment.

(f) With regard to material agricultural encouragement, tariffs, bounties, subsidies, loans, and the like.

(g) With regard to the development, utilization and conservation of natural resources.

(h) With regard to rural education, rural life and means of communication.

9. Agricultural commerce and trade, including both domestic and international trade.

IO. Consumption and the relation of consumers to the food supply. In other words, it is advanced that an agricultural policy should have as a chief consideration the consumers' demand for agricultural foodstuffs and the raw materials of clothing and that a policy should be developed on the basis of a study of the food requirements of different sections of the coun- 
try and the possibility of producing these food requirements most economically.

On the following pages the reviewer has attempted to classify the various items presented by the correspondents, none of whom developed a comprehensive program. Consequently, the "Tentative outline of an American Agricultural Policy " inserted below may be considered to include the items just stated and in addition some fields which the correspondents have omitted and which in the opinion of the reviewer are essential in a comprehensive agricultural policy.

\section{AMERICAN AGRICULTURAL POLICY TENTATIVE OUTLINE}

Inasmuch as no one person is responsible for the complete outline of an agricultural policy and since the problem was presented in this correspondence from several viewpoints, I have endeavored to classify the items under a few commonplace headings. I have attempted to set forth as fairly as possible the consensus of opinion on the several items. The resulting outline is somewhat detailed and may seem to some too comprehensive. It is clear, however, that no matter how short and simple may be the final statement of policy, it will be necessary first to consider the problem in its ramifications in order to balance conclusions and escape contradictions and narrow temporalities. At best the outline is tentative merely and will at least serve for purposes of discussion.

\section{Fundamental Principles}

I. Economically, an agricultural policy should be approached from the point of view of maintaining the supply of food and other raw materials of agriculture for the nation or for the world.

2. Nationally, two possible policies may be pursued:

(a) To make the nation self-sufficing with regard to food and other agricultural raw materials, that is to pursue an agricultural policy which will maintain the balance 
between agriculture and other industries within the nation;

(b) To purchase our food supply in the lowest market and pay for it with manufactured goods;

The policy chosen should be determined by the best interest of the country as a whole.

3. Individually, the farm should provide its workers with as good a living and as good an opportunity for development and should open as many important avenues of public recognition as any other calling.

4. The guiding principle should be to establish and maintain such farming conditions as will best serve the interest of society as a whole. Agriculture should receive a fair reward. The other classes of society sliould not be compelled to pay too high a price for food and clothing.

5. In formulating a policy the sociological aspect should be kept always in view. Life is primarily spiritual, intellectual, social and economic.

\section{Production}

1. The basis of encouragement of agricultural production should rest on an adequate remuneration for the farmer, based on the cost of production plus a fair insurance against seasonal risks.

2. The independence of the farm operator should be insured either by giving him easy opportunity to own the land he operates or by safeguarding his investment in improvements, encouraging longer tenure and better farm practice, and conserving soil fertility by judicious legislation regarding tenant right.

3. Credit. The farmer's credit facilities should be enlarged by :
(a) Better facilities for short time credit on a national basis; (and perhaps)
(b) A system of banks, specifically agricultural, to deal with farm credit requirements as our present system deals chiefly with urban credit needs; 
(c) Farm and stored products; the farm business as a going concern as well as character, industry and farm experience should be bases for farm loans.

4. Machinery. The economical use of modern farm machinery and appliances should be encouraged by official inspection of such machinery, particularly tractors, electrical appliances and motor-driven implements, so that farmers may be protected in their purchases and the waste of farm capital invested in untried machines prevented.

5. Farm labor.

(a) The basic wages, hours, housing facilities and conditions of employment of farm laborers should be standardized as far as possible;

(b) Provision should be made for the training of agricultural laborers;

(c) Laborers' cottages, longer terms of employment, employment of married men, yearly contracts and the giving of a bonus or a material interest in the farm enterprise to the laborer in addition to wages should be encouraged ;

(d) The supply and seasonal distribution of laborers should be perfected through the establishment of government labor bureaus with local branches.

6. Seed. Measures should be taken to encourage the production of good varieties of pure seed, and to insure the supply of good seed and the protection of the buyer against adulterated or impure varieties. Especial attention should be given to procuring legume seed.

7. Live stock. The plan should include government encouragement and assistance in live stock breeding, chiefly by means of community enterprises.

8. Conservation measures.

(a) Provision for the supply of unlimited quantities of lime for agricultural needs;

(b) The restriction of exports of mineral phosphates;

(c) A comprehensive plan for the manufacture of syn- 


\section{THE FARMER AND THE NEW DAY}

thetic ammonia, nitrates and other nitrogenous fertilizing materials;

(d) Production of adequate quantities of potash to preclude the necessity of importing this material;

(e) Protection of agricultural land against erosion and overflow;

(f) Proparyanda regarding the advantages of tile draining and provision for the necessary supply of tile where needed;

(g) Statement of a definite policy regarding the exportation of our agricultural products, grains, cottonseed oil cake and the like which can be fed to live stock at home.

9. A land and reclamation policy.

To what extent is it desirable to encourage increased agricultural population, increased area of cultivated land and consequently increased agricultural production merely to lower the prices of agricultural products?

(a) Formulation of a constructive policy with regard to land settlement and colonization, first for returning soldiers, second for other prospective farmers:

(b) This policy should definitely determine the following points:

(1) The supervising and directing authority

(aa) Government - federal or state or both;

(bb) Private real estate agencies;

(cc) Both governmental and private agencies.

(2) Location of settlement.

(aa) In limited regions, on hitherto unoccupied tracts, in the newer states, probably distant from settled agriculture and markets;

(bb) Scattered settlements in the older or home states;

(cc) On reclaimed lands or on unimproved lands once in farms. There are many very valid reasons why new settlers, not experienced farmers, 
should find farm homes in the older settled communities. The benefits of such home settlements accrue both to the older community and to the settler. Moreover there are obvious disadvantages in new and untried territories distant from markets and the conveniences of civilization.

(3) Conditions of settlement.

(aa) Qualifications of the settler - citizenship, agricultural experience, length of residence;

(bb) Restrictions on transfer of land and change of residence;

(cc) Material aid and equipments furnished the settler, for example, agricultural advice, credit, buildings and equipment, supplies;

(dd) Size of holdings permitted.

Should there be different policies in the different states or for different types of settlement with government protection and assistance in all instances?

(ee) Legislation to prevent land speculation, exploitation and attendant evils.

(4) A comprehensive reclamation policy under state or federal auspices, including drainage, irrigation, diking, clearing unimproved land.

(aa) To open new land;

(bb) To provide employment for prospective settlers;

(cc) To relieve industrial unemployment after the war.

(5) A comprehensive immigration policy.

10. Control of diseases and pests, both of animal and plants. The policy should include adequate laws, both national and state, and outline provisions for agricultural insurance against weather, disease and pest conditions.

\section{Distribution}

On no point is there more uniform agreement than on the 


\section{THE FARMER AND THE NEW DAY}

necessity for a definite policy with regard to the marketing and distribution of agricultural products. Needless to say there is disagreement on the details or even principles underlying such a policy. Some points of general agreement are as follows:

I. Much greater emphasis by investigators, educators, rural leaders and administrators on the discovery and dissenination of facts and principles of scientific marketing. The conviction that distribution problems have been slighted by agricultural leaders and educators is definite and pronounced.

2. Business organization. Organization of farmers' corporations for marketing and wholesale handling of products.

(a) The purposes are economic handling, preparation for consumption, grading, standardizing, advertising, climinating wastes, storing, utilizing by-products, transporting, equalizing distribution and providing requirements of raw materials in quantity at wholesale prices;

(b) Collective bargaining by farmers under adequate protective legislation to safeguard both farmers and consumers;

(c) Preparation, cleaning, packing and primary manufacture of farm products, especially the manufacture of byproducts and culls by farmers' corporations for the purpose of conservation of food, saving of transportation and increasing returns to the farmer.

3. Transportation.

(a) Government aid in the planning and building of highways. Government ownership of highways is suggested as practicable and more desirable than ownership of railways;

(b) Encouragement of motor truck, freight and trolley express for farm products;

(c) Revision of freight rates with a view to agricultural needs and economic distribution;

(d) Shipment of partially prepared or finished products rather than raw materials of agriculture. Approval 
of this policy would mean the encouragement of factories for the manufacture of agricultural products much nearer the points of consumption than pre-war conditions of competition seem to justify.

4. Grades. Establishment of national grades and standards for farm products.

5. Government control. Control distributing agencies, lessen waste, cheapen distributing costs and provide adequate facilities for handling food products either by government ownership of the mechanism of distribution or by government control through the licensing of middlemen and regulation of middlemen's prices, charges and methods or by government price fixing.

6. More stringent regulation to prevent adulteration, misbranding, etc.

Adclitional projects advocated by a minority.

7. Storage and warehouse facilities constructed, operated or controlled by government to restore the balance of underor over-production of food or prevent gluts and shortages and to stabilize prices.

8. Regulation of exports of raw agricultural products.

9. Encouragement of farmers' markets and means of direct marketing to utilize products for consumption as near the source of supply as possible and provide the consumer with fresh food materials.

IV. Rural Education.

Principle, to make available to farmers' sons and daughters as sutisfactory educational advantages as are offered to any children in the country.

I. Federal aid to rural schools, chiefly because it is impossible to provide adequate educational facilities to rural children by local taxation;

2. The creation of adequate rural educational facilities of both primary and secondary grade. Much emphasis is laid on the necessity of providing secondary school education for rural children; 


\section{THE FARMER AND THE NEW DAY}

3. Better teachers with rural outlook and ideals of rural leadership at better wages;

4. Teacherages and possibly consolidated schools with the idea of making the rural school teacher a permanent addition to the leadership of the rural community;

5. More attention to agricultural economics and rural sociology in secondary schools and colleges where farmers and rural leaders are trained;

6. Expansion of research facilities in experiment stations to include problems of agricultural economics and social studies ;

(a) A revision and reconstruction of the curricula of colleges in order that college teaching may be brought in line with the national agricultural policy both with regard to production and distribution. More especially much greater emphasis should be placed on the teaching of agricultural economics and rural life subjects to all agricultural teachers and leaders in agriculture. The American agricultural policy as such should be given a place among the courses offered by our department of agricultural economics and all college students should be required to give attention to the broader phases of agriculture.

7. Organization of research in current problems as well as in long-time investigation;

8. Schools for the training of rural leaders and managers of farmers' business organizations.

\section{Religious Life.}

The revitalization of the rural church and the recognition of the rural church as an essential factor in the development of a rural community.

Details as to the reorganization and development of the rural church as a factor in rural life affairs are lacking. It is significant, however, that there is wide agreement on the general principle above stated. 


\section{A POLICY}

\section{Health and Sanitation.}

In matters of health and sanitation our urban communities have long worked on a definite policy looking to the protection of public and private health. The state departments of health have thus far concerned themselves almost wholly with the welfare of cities. No policy or program especially applicable to the rural districts has been adopted. As a result of this negligence, it has come to be true that preventable diseases are largely rural diseases. Rural districts should be the most healthful in the country. The national Public Health Service should establish forthwith a rural health bureau, and each state, if not each county, should have a similar bureau, with physicians, sanitarians and nurses in connection therewith.

\section{Country Life.}

After all the spiritual and social side of rural life is the important side. Opportunity for better living, leisure for appreciation, wholesome recreation, community activities, social and intellectual, must be contemplated by makers of an agricultural policy. We should aim to create a proper appreciation of agriculture as a business not only among those who are not engaged in it but among those who are engaged in it. Agricultural problems are not different from other problems except as made so by the isolation of the people.

\section{Government Relations.}

It is very essential in any agricultural policy that the relation of the government to various phases of agricultural and agricultural activities should be definitely stated. In general the definition of government relationships should be crystallized in law. But it is clear that no agricultural policy can proceed very far without taking into consideration the attitude of the government toward the various items in the program. A number of these governmental relationships, perhaps all of them, have been indicated in the outline. They are grouped together under this heading in order that they may be viewed as a whole. The relationship of the government to agriculture and to farmers should be clear with regard to: 


\section{THE FARMER AND THE NEW DAY}

\section{(a) Political representation of agriculture in the state and nation;}

(b) Corporations of farmers for collective bargaining and for other economic purposes;

(c) Control of prices of agricultural products, trade and commercial practices in distribution;

(d) Land, land settlement, immigration and the financing of the farm enterprise;

(e) Taxation of land and farm equipment;

(f) The unearned increment in land;

(g) The development, utilization and conservation of soil and other natural agricultural resources, fertilizing materials.

(h) Exportation of raw agricultural products, especially those suitable for the feeding of live stock ;

(i) Material agricultural encouragement, tariffs, bounties, subsidies, agricultural advice and assistance, loans, etc.

(j) The ownership and control of means of transportation and distribution, including highways, railways, storage facilities, manufactories of agricultural products and oiher distributing agencies and institutions;

(k) Rural education and agricultural education, both for children and for adults;

(1) Rural health and sanitation;

(m) Means of rural communication;

(n) Rural policing;

(o) Government employment agencies for employing agricultural labor;

(p) Agricultural trade and commerce, foreign and domestic;

(q) Agricultural credit.

IX. The Coördination of the Economic, Educational and Administrative Forces in Agriculture.

Some definite steps should be taken to coördinate

I. The agricultural colleges, experiment stations, extension services and the United States Department of Agriculture 
under one bureau or department in order that there may be perfect understanding and collaboration in education and research work, that friction may be avoided and duplication of work eliminated.

2. Coördination between county, state and national authorities in agricultural affairs is necessary and should be a part of an agricultural policy.

3. The organization of farmers' organizations, both business and social, agricultural leaders, educators and others interested in country life into a national chamber or council of agriculture under a rational, systematic and practicable plan is certainly a part of any agricultural policy.

IV. HOW CAN SUCH A POLICY BEST BE FORMULATED AND ALL AGRICULTURAL AGENCIES RALLIED FOR ITS EXECUTION?

Thoughtful men are by no means agreed on the authority for formulating a program and perhaps more disagreed on the execution of it. Aside from representative farmers and stockmen at least 20 groups of men were suggested as having a part individually or collectively in the formulation of a program. Ten of these represent publicly supported agricultural agencies, educational or administrative in character. Two are associations of agricultural economists. Five are great farmers' organizations or federations of farmers' associations. The others represent the rural and agricultural press, the banks and legislative bodies, state and federal.

I. In general one may distinguish four groups: first, those who would assign the formulation of a policy to the state agricultural (educational) agencies and the United States Department of Agriculture, generally in coöperation with the state commissioners of agriculture. Due perhaps to the source of the replies there is very general agreement that representatives of the agricultural colleges, experiment stations and the United States Department of Agriculture should assume the responsibility in whole or large part for the formulation of an agricultural policy. It is interesting that comparatively few deans, directors or presidents of agricultural colleges or stations have suggested farmers 


\section{THE FARMER AND THE NEW DAY}

or farmers' organizations in connection with the formulation of a program. None of them gave any place to consumers or trade organizations interested in agricultural products.

2. Those who approve an independent commission, appointed by the President or by Congress, at least having federal authority, composed of agricultural leaders. There is no general agreement on the constitution of this commission. Various suggestions are offered:

a. That it should represent all sections of the country and all phases of the subject.

b. That leaders in education, journalism, politics, medicine and law, together with leaders within the agricultural colleges, should compose it.

c. That it should be composed of both men and women.

3. Some voluntary conference committee or group of which farmers, representatives of farmers' organizations and economists should form a prominent part. A few men would have farmers or farmers' organizations formulate and carry through the program. Others would submit a plan formulated by some agricultural group to the farmers for discussion and acceptance. At least two men suggest that the American Association for Agricultural Legislation is the proper body to draw up the policy for submission to the agricultural interests.

4. A conference or regional conferences, made up of groups one and three, for discussion and formulation, the policy to be put in operation by various educational and administrative publicly supported agencies and by executive action following legislation. A conference of this sort, while perhaps not definite in constitution, is the answer to those who feel that an agricultural policy should be formulated by a large number of agricultural interests. It is probable that any conference thoroughly representative of agriculture and agricultural leaders would be satisfactory. Differences in the agricultural problems of different regions account for the proposal of regional conferences.

Note: The American Agricultural Policy Conference Group which follows is presented by the reviewer as suggestive merely. None of the correspondents have suggested all of 
the agencies listed in this group. Many of them suggested a number of agencies and of course many of the suggestions are vague. This group not only includes the publicly supported agricultural agencies and farmers' organizations, but economists, associations of farm women, trade organizations and rural sociologists. The agricultural press and other groups manifestly have an interest in the formulation of an agricultural policy.

\section{CONFERENCE GROUP}

An ideal conference would include all groups considered in the preceding report and certain others which have not been suggested. For example, although none have mentioned consumers' organizations or consumers, it is evident that to consumers America's agricultural policy would be a matter of vast importance. Many items in the agricultural program here presented are intimately related to the transportation agencies, storage corporations, manufacturers of agricultural products and agricultural requirements as well as to distributors of foods.

The following tentative list attempts to include the more important interested groups:

I. Publicly supported agricultural agencies, educational and administrative

a. United States Department of Agriculture

b. United States Food Administration

c. Agricultural colleges, experiment stations and extension divisions - represented in the American Association of Agricultural Colleges

d. State commissions of agriculture

e. Association of State Marketing Officials.

II. Associations of Economists

a. American Association of Agricultural Economists

b. American Association for Agricultural Legislation

c. American Farm Management Assaciation.

III. Farmers' Organizations

a. American Society of Equity 
b. Farmers' Coöperative and Educational Union

c. National Farmers' Congress

d. National Federation of Milk Producers

$(\mathrm{a}, \mathrm{b}, \mathrm{c}$, and $\mathrm{d}$ are represented in the National Board of Farm Organizations.)

e. Grange

f. National Live Stock Association

g. National Council of Farmers' Coöperative Associations (grain growers)

h. Right Relationship League.

IV. Farm Women's Organizations

a. International Congress of Farm Women

b. National Farm and Garden Association

c. Women's Land Army of America.

V. Trade Associations
a. Chamber of Commerce of the U. S. A.
b. National League of Commission Merchants
c. Meat Packers' Association
d. National Poultry, Butter and Egg Association
e. Grain Dealers' National Association
f. National Association of Cotton Manufacturers
g. National Retail Grocers' Association
h. National Hay Association.

VI. Voluntary Organizations or Groups Concerned with the Agricultural Policy
a. Agricultural Policy Group
b. U.S. D. A. Agricultural Mission
c. Committee of Twenty-Four - Advisory Council.

VII. Consumers' Organizations
a. Coöperative League of America
b. Consumers' League
c. Housewives' League
d. American Federation of Labor. 


\section{A POLICY}

VIII. Allied Organizations

a. Russell Sage Foundation

b. Carnegie Institution

c. Rockefeller Institute

d. American Bankers' Association.

IX. Individual Representative Agricultural Leaders and Farmers. 

$T^{H E}$ following pages contain advertisements of a few of the Macmillan books on kindred subjects. 



\title{
NEW FARM AND GARDEN BOOKS
}

\section{The Nursery Manual}

\author{
By L. H. BAILEY
}

With Illustrations

Cloth, I2mo., Preparing.

Professor Bailey's Nursery Book is the foundation of this volume, though the original has been entirely re-written and re-illustrated and appears now in The Rural Manual Series.

The book may be described as a complete guide to the multiplication of plants, aiming to give an account of the methods commonly employed in the propagation and crossing of plants.

The handling and sowing of seeds and spores, separation and division, layerage, the general requirements of cuttings and the various kinds, grafting, budding, nursery management - these are some of the topics taken up.

The illustrations are all from new drawings and photographs.

\section{Manual of American Grape Growing}

\author{
Bx U. P. HEDRICK
}

Horticulturist of the State Experiment Station, Geneva, N. Y. With Illustrations

Cloth, $12^{\circ}$, Preparing.

This is written as a complete popular treatise on grape-growing in North America. It discusses the practical questions of climatic limitations, choice of site, land and its preparation, fertilizing, tillage, planting, pruning and training, and marketing. It also has concise treatment of the diseases and the insects injurious to the grape. Special attention is given to descriptions of the leading commercial and amateur varieties. Part of the book is devoted to the vinifera grape as grown in California.

Professor Hedrick has had long experience in the study of the grape in all its aspects, and the book will be found to be a useful, up-to-date manual of propagation, manipulation, and the handling of the crop. It is well illustrated by full-page olates and also by engravings in the text.

\section{THE MACMILLAN COMPANY Publishers 64-66 Fifth Avenue New York}




\title{
NEW FARM AND GARDEN BOOKS
}

\section{The Sugar-Beet in America}

\author{
BY F. S. HARRIS \\ Director of the Utah Experiment Station \\ Illustrated, $12^{\circ}, \$ 2.25$
}

Here is a thorough and practical guide book for farmers who are raising sugar-beets, for agriculturists in sugar companies, and for students of the sugar-beet in agricultural colleges.

Dr. Harris has assembled here all the important facts and details regarding the raising and cultivation of the sugarbeet. There is also an account of the processes involved in the manufacturing of sugar from the beet, and a discussion of the sugar-beet's commercial rival, cane sugar.

A special feature of the book is the large number of illustrations - over 32 plates, with maps, diagrams and charts - clarifying the text and adding much to the practical value of the book.

\section{Peach-Growing}

\section{By H. P. GOULD}

Pomologist in Charge of Fruit Production Investigations Bureau of Plant Industry, U. S. Department of Agriculture

\section{Illustrated, $12^{\circ}, \$ 2.00$}

Here is a book which covers the general field of growing peaches and placing them within reach of the consumer.

It is practical. It is detailed. It is a handbook for peachgrowers of North and East, as well as South and West.

Peach literature has been notably limited, except for experiment station bulletins and reports. This book gathers into one compact, fully illustrated volume the principles and practice of successful peach production.

\section{THE MACMILLAN COMPANY Publishers 64-66 Fifth Avenue New York}




\title{
Cyclopedia of American Agriculture
}

\section{EDITED By L. H. BAILEY}

With 100 full-page plates and more than 2,000 illustrations in the text; four volumes; the set, $\$ 20.00$

Vol. I-Farms

Vol. II-Crops
Vol. III-Animals

Vol. IV-The Farm and the Community

This is unquestionably the most important agricultural cyclopedic work published in this country. The leading experts in the United States and Canada, both investigators and practical farmers, contribute to its chapters, which are arranged not alphabetically, but topically, each subject being treated in its various aspects by men especially familiar with it.

"Indispensable to public and reference libraries ... readily comprehensible to any person of average education." - The Nation.

"The completest existing thesaurus of up-to-date facts and opinions on modern agricultural methods. It is safe to say that many years must pass before it can be surpassed in comprehensiveness, accuracy, practical value, and mechanical excellence. It ought to be in every library in the country."-Record-Herald, Chicago.

\section{The Standard Cyclopedia of Horticulture}

\author{
EDited By L. H. BAILEy \\ With the Assistance of over 500 Collaborators \\ Now complete in 6 vols. \\ Set, cloth, $\$ 36.00$
}

"No one who knows anything at all about the literature of gardening needs to be told that the Cyclopedia is unique. It is the Bible and Britannica of the garden-folk, amateur and professional alike. And the remarkable thing is that while it is fundamentally a work of reference, it also contains limitless quantities of good reading of the sort dear to the heart of the garden enthusiast."-The Nation.

"It is no exaggeration to state that Bailey's new work is the best Cyclopedia obtainable for all who are connected, either remotely or intimately, as amateurs or professionals, with horticultural pursuits." - The Florists' Review.

\section{THE MACMILLAN COMPANY \\ Publishers 64-66 Fifth Avenue New York}




\title{
Co-Operation \\ The Hope of the Consumer
}

\author{
BY EMERSON P. HARRIS
}

President of the Montclair Co-operative Society

With an Introduction by John Graham Brooks

Cloth, $12^{\circ}, \$ 2.00$

This new book meets the problems of merchandising in an original, sane and suggestive way, and gives an approach to the subject of co-operation which is of far more than academic value. Mr. Harris through his close association with the co-operative movement, has come into frequent - contact with the actual working of the plan, and has embodied in this volume a treatment of the subject that is notably fresh and practical.

"The volume is splendid," he writes, "really splendid. I do not know of any Socialist literature that so convincingly shows up the disorder of capitalist distribution as this one. To my mind it is the first book of the coming literature on the great co-operative movement of the future. It is going to make American co-operators by the thousands, perhaps by the hundreds of thousands."

- Mr. Albert Sonnichsen, well known author.

"Frank and sincere and open hearted. . . The author is full of his subject and writes from a brimming reservoir of facts.... His earnestness and devotion are manifest in all the twenty-four chapters of this interesting and suggestive treatise. . .

A carefully written and useful book. It should have a wide circulation and reading."

- The Evening Sun. 







\section{LIBRARY OF CONGRESS}

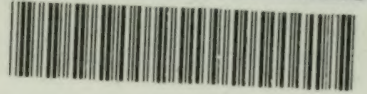

व0027484426 